\title{
Gold in Paleoproterozoic (2.1 to 1.77 Ga) Continental Magmatic Arcs at the Tapajós and Juruena Mineral Provinces (Amazonian Craton, Brazil): A New Frontier for the Exploration of Epithermal-Porphyry and Related Deposits
}

\author{
Caetano Juliani ${ }^{1, *}$, Rafael Rodrigues de Assis ${ }^{1}$, Lena Virgínia Soares Monteiro ${ }^{1}$, \\ Carlos Marcello Dias Fernandes ${ }^{2}$, José Eduardo Zimmermann da Silva Martins ${ }^{1}$ \\ and Jhoseph Ricardo Costa e Costa ${ }^{2}$
}

check for

updates

Citation: Juliani, C.; Rodrigues de Assis, R.; Virgínia Soares Monteiro, L.; Marcello Dias Fernandes, C.; Eduardo Zimmermann da Silva Martins, J.; Ricardo Costa e Costa, J. Gold in Paleoproterozoic (2.1 to $1.77 \mathrm{Ga}$ ) Continental Magmatic Arcs at the Tapajós and Juruena Mineral Provinces (Amazonian Craton, Brazil): A New Frontier for the Exploration of Epithermal-Porphyry and Related Deposits. Minerals 2021, 11, 714. https://doi.org/10.3390/ $\min 11070714$

Academic Editors: Lydia Maria Lobato, Rosaline Cristina Figueiredo e Silva and Steffen Hagemann

Received: 4 March 2021

Accepted: 24 June 2021

Published: 1 July 2021

Publisher's Note: MDPI stays neutral with regard to jurisdictional claims in published maps and institutional affiliations.

Copyright: (c) 2021 by the authors. Licensee MDPI, Basel, Switzerland. This article is an open access article distributed under the terms and conditions of the Creative Commons Attribution (CC BY) license (https:/ / creativecommons.org/licenses/by/ $4.0 /)$.
1 Instituto de Geociências, Universidade de São Paulo-USP, Rua do Lago 562, São Paulo 05508-080, Brazil; assis.rafael@usp.br (R.R.d.A.); lena.monteiro@usp.br (L.V.S.M.); jegeologia@usp.br (J.E.Z.d.S.M.)

2 Instituto de Geociências, Universidade Federal do Pará-UFPA, Rua Augusto Corrêa 1, Belém 66075-110, Brazil; cmarcello31@gmail.com (C.M.D.F.); jhosephcosta@gmail.com (J.R.C.e.C.) * Correspondence: cjuliani@usp.br

Abstract: This review paper aims to integrate geological, tectonic and metallogenetic data, including new data, and propose a regional model for the gold (and base metal) mineralization in the south Amazonian Craton to support the mineral exploration concerning magmatic-hydrothermal deposits. The Proterozoic evolution of the Amazonian Craton comprises the accretion of terrains to the Archean Carajás Mineral Province. In the Tapajós and Juruena mineral provinces, located at the south part of the Amazonian craton, a long-lived ocean-continent subduction event produced ca. 2.0 to $1.77 \mathrm{Ga}$ continental magmatic arcs. Extensive lava flows, volcaniclastic, sedimentary, and plutonic rocks were originated during at least four major orogenic magmatic events (ca. 2.1, 1.9, 1.88 , and $1.80 \mathrm{Ga}$ ) and two post- to anorogenic events (ca. 1.87 and $1.77 \mathrm{Ga}$ ). Gold mineralization occurs in: (i) alluvial/colluvial occurrences, (ii) orogenic carbonate-sulfide-rich quartz veins in shear zones, (iii) stockworks, veins, and dissemination in granites, (iv) contact of basic dikes, (v) wellpreserved high-, intermediate- and low-sulfidation epithermal mineralization, and (vi) porphyry-like and intrusion-related gold systems associated with late- to post-orogenic epizonal granites. The estimated historical gold production, mainly in secondary deposits, is over $27 \mathrm{Moz}$ at the Tapajós and $6 \mathrm{Moz}$ at the Juruena provinces. A total resource of over $5 \mathrm{Moz} \mathrm{Au}$ is currently defined in several small to large primary gold deposits. Andesite to rhyolite, volcaniclastic, and clastic sedimentary rocks (1.96-1.88 Ga) host epithermal (high-, intermediate-, and low-sulfidation) $\mathrm{Au}-(\mathrm{Ag}-\mathrm{Pb}-\mathrm{Zn})$ mineralization, whereas $\mathrm{Au}-\mathrm{Cu}$ and $\mathrm{Cu}-\mathrm{Mo}-\mathrm{Au}$ mineralization is hosted in sub-volcanic tonalitic to granitic plutons. Advanced argillic alteration (alunite, pyrophyllite, enargite) associated with high-sulfidation mineralization occurs in ring volcanoes around nested volcanic calderas. This zone grades outward to propylitic or chlorite alteration, often covered by silica caps with vuggy silica. Lava flows and volcaniclastic rocks within faults or associated with volcanic edifices and rhyolitic domes host low- and intermediate-sulfidation mineralization. Low-sulfidation alteration zones typically have adularia and illite or sericite. Chalcopyrite, sphalerite, galena, pyrite, digenite, and manganiferous calcite are related to intermediate-sulfidation gold mineralization. Late- to postorogenic evolved oxidized I-type granitoids host alkalic-type epithermal and porphyry-like gold mineralization. Porphyry-style hydrothermal alteration is analogous to those of modern systems, with inner sodic and potassic (potassic feldspar \pm biotite or biotite) alterations grading to propylitic, muscovite-sericite, chlorite-sericite, and chlorite alterations. Potassic alteration zones are the locus of $\mathrm{Cu}-\mathrm{Mo}$ mineralization, and gold-rich zones occur in muscovite/sericite-quartz-pyrite alteration. The Paleoproterozoic epithermal and porphyry-like mineralization in these large provinces defines a new frontier for the exploration of world-class gold deposits in the worldwide Proterozoic arc-related magmatic terrains. 
Keywords: Amazonian Craton; Paleoproterozoic; gold; epithermal; porphyry; hydrothermal alteration; Tapajós Mineral Province; Juruena Mineral Province; magmatic arcs

\section{Introduction}

The Tapajós and Juruena (or Alta Floresta) mineral provinces have been responsible for decades of significant Brazilian gold production. Gold was discovered in the Tapajós in 1958 in alluvial deposits of the Tropas river [1]. Between 1970 and 1990, the Tapajós region has become the largest gold producer in Brazil, with up to around 100,000 manual miners ("garimpeiros") working in hundreds of small mines in placers, paleoplacers and colluvial deposits. With the exhaustion of many of these secondary deposits and governmental controls on environmental degradation caused by artisanal mining, the production declined, opening opportunities to the mineral exploration of primary deposits by mining companies. At the Juruena Mineral Province (JMP), the gold occurrences were discovered in 1978, initially in alluvial placers due to the construction of the BR163 federal highway [2]. Dozens of small-size (usually $<5 \mathrm{t} \mathrm{Au}$ ) and high-grade gold placers and granite-hosted veins and disseminations have been exploited by artisanal prospectors or mining companies, the majority of them without geological studies and previous resource measures. Conservative estimates indicate a gold production of at least $900 \mathrm{t}$ in the TMP and $250 \mathrm{t}$ at the JMP until today in secondary deposits and few small high-grade quartz-sulfide lode mines.

The challenging access due to the rain forest and few roads, the geological knowledge only on a regional scale, few metallogenetic studies, and the lack of a clear definition concerning the Paleoproterozoic tectonic environment and petrogenesis precluded the preposition of comprehensive metallogenetic models for gold and copper-molybdenum mineralization. For many years, the ca. $1.88 \mathrm{Ga}$ felsic magmatism of the TMP was considered exclusively as related to post-orogenic to intracratonic A-type magmatism [3-8] with only a major potential to tin deposits. This interpretation excluded the possibility of subduction-related magmatic-hydrothermal ore deposits, especially the epithermal and porphyry types, despite the presence of calc-alkaline andesite, rhyodacite, dacite and rhyolite units of such age. Besides this, a large number of gold occurrences and small mines, spatially related to ca. 2.1 to 1.88 Ga volcano-plutonic rocks at the TMP, and until ca. $1.77 \mathrm{Ga}$ in the JMP, led the proposition of distinct metallogenetic models for the gold mineralization in both provinces. The pioneering studies proposed ore-forming processes linked to "mesothermal and epizonal" orogenic [1,8-10] and intrusion-related [1,11] deposits post- or later than the ca. $1.88 \mathrm{Ga}$ A-type magmatic event [1]. With the prevalence of the orogenic gold genetic model for several years, especially at the Tapajós, major and junior mining companies focused on exploring this model during the 1980s to 2000s, but few significant gold resources were found.

The discovery of a well-preserved high-sulfidation epithermal gold mineralization associated with 1.88 Ga calc-alkaline volcanic rocks by Rio Tinto company [12-16] and porphyry-like gold systems [17-20] opened the possibility for the occurrence of large Paleoproterozoic gold and $\mathrm{Cu}-\mathrm{Mo}$ deposits in both provinces, as proposed by [21]. In the following years, due to academic research and mineral exploration programs, several epithermal (low-, intermediate- and high-sulfidation) occurrences related to calc-alkalic and alkalic porphyry-like mineralization, sometimes with $\mathrm{Au}, \mathrm{Cu}$ or $\mathrm{Mo}$, were identified in both provinces [22-36]. This expands the perspectives for the existence of magmatichydrothermal high-grade epithermal and large porphyry-like deposits. More recently, rumors of the discovery by Anglo American of the Jaca $\mathrm{Cu}-(\mathrm{Mo})-(\mathrm{Au})$ porphyry deposit [37] in the JMP stimulated a new exploration rush and intense land claims in both provinces.

Despite the remarkable improvement of the knowledge on the mineral deposits, magmatism, and tectonic evolution of the Tapajós and Juruena mineral provinces in the last decades, rare studies deal with a comprehensive integration of the available data [38-41]. 
In this paper, we report a review concerning the ore resources and grades, mineralizing styles, hydrothermal alteration, geochronological and isotope data, and document the relationship among several magmatic events, later fault zones and the primary gold-basemetals mineralization in the Tapajós and Juruena provinces.

This contribution presents a review of the geology and metallogenesis of gold in the Paleoproterozoic Tapajós and Juruena mineral provinces in the Amazonian Craton, unraveling the interplay among tectonic setting, magmatism and associated gold mineralization, supplying data, and triggering a reliable conceptual exploration model for the mineral industry.

\section{Tectonic Setting of the Tapajós and Juruena Mineral Provinces}

The understanding of the Paleoproterozoic tectonic evolution of the Amazonian Craton is still incomplete and challenging. Geochronological and isotopic constraints lead several authors to proposed several oceanic-oceanic (island arcs) and oceanic-continental plates subduction and accretionary events towards the Archean Carajás-Iricoumé block between ca. 2.2 to $1.75 \mathrm{Ga}[5,42,43]$.

According to $[43,44]$, the Amazonian Craton is divided into six geochronological provinces (Figure 1), with accreted belts successively younger towards the southwest: Central Amazonian (>2.5 Ga), Maroni-Itacaiúnas (2.2 to $1.9 \mathrm{Ga}$ ), Ventuari-Tapajós (1.9 to $1.8 \mathrm{Ga})$, Rio Negro-Juruena (1.80 to $1.55 \mathrm{Ga})$, Rondonian-San Ignácio (1.55 to $1.30 \mathrm{Ga}$ ), and Sunsás (1.25 to $1.00 \mathrm{Ga})$. Reference [45], based on [5], subdivided the Amazonian Craton into eight geochronological-tectonic provinces, also youngling to the southwest, such as Carajás ( 3.0 to $2.5 \mathrm{Ga}$ ), Transamazonic (2.26 to $2.06 \mathrm{Ga}$ ), Tapajós-Parima (2.03 to $1.86 \mathrm{Ga})$, Central Guyana (1.95 to $1.81 \mathrm{Ga})$, Central Amazonian (1.90 to $1.86 \mathrm{Ga})$, RondôniaJuruena (1.85 to $1.54 \mathrm{Ga}$ ), Rio Negro (1.82 to $1.52 \mathrm{Ga}$ ), and Sunsás (1.45 to $1.00 \mathrm{Ga})$. These authors also individualized the Iriri-Xingu, Tapajós, and Peixoto de Azevedo domains in the Central Amazonian Province. In the first domain, the felsic units, interpreted as an anorogenic volcanic cover, predominate. The latter was considered an NW-SE southeastward extension of the Tapajós Domain, crosscutting the E-W-trending tectonic structure of the Rondônia-Juruena Province. 


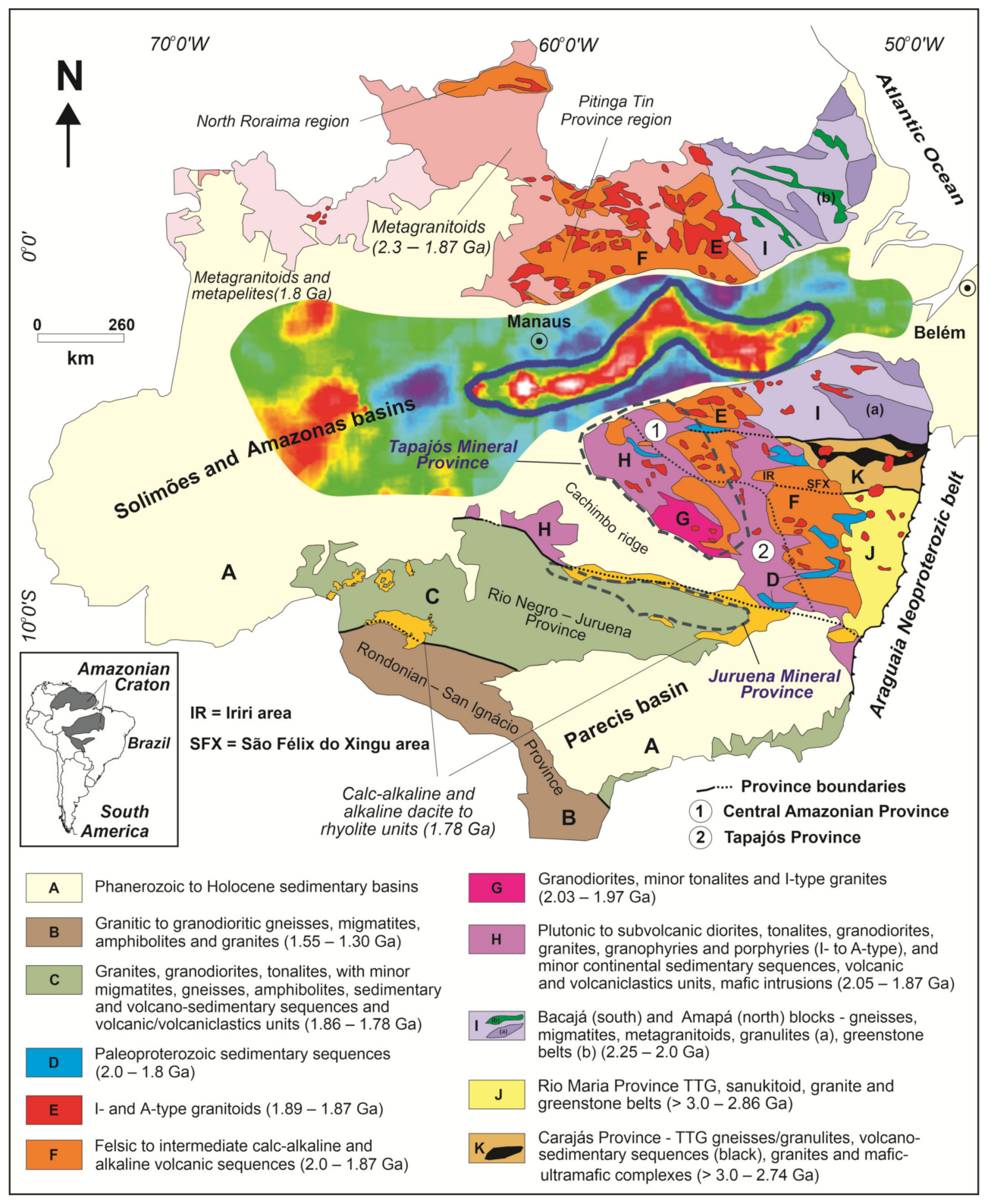

Figure 1. Geological and tectonic settings of the Tapajós and Juruena mineral provinces in the Amazonian Craton, modified from [46]. Geochronological provinces based on [44]; tectonic domains by [5]. Gravimetry of Solimões and Amazonas basins, with main Bouguer anomaly defined by the blue line (variation from +60 to $-70 \mathrm{mGal}$, hot to cold colors) is from [47].

The NW-SE-oriented Ventuari-Tapajós Province [43,44] is truncated by the approximately E-W-trending Phanerozoic Amazonas basin and is in contact with the Central Amazonian Province (Figure 1) to the west and the Rio Negro-Juruena Province to the south. A strong gravimetric and magnetic anomaly under the Amazonas basin [47], along its axis, was interpreted as related to ca. 570 Ma pyroxenite and Mesozoic intrusive mafic bodies [48-50]. Such anomaly was also previously interpreted as a suture between two amalgamated Archean terrains, named Guyana, in the north, and Guaporé (or Central Brazil), in the south [51]. The junction of the north and south blocks in a single NW-SE block was proposed by [52] based on the similarity of the rock ages and mineral occurrences. Consequently, the Ventuari-Tapajós Province is formed by the Ventuari (or Parima) Domain, at the north, and the Tapajós Domain at the south of the Amazonas basin.

The Tapajós Mineral Province (TMP), also named Tapajós Gold Province, comprises the south part of the Ventuari-Tapajós Province (1.9 to $1.8 \mathrm{Ga}$; [43,44] (Figure 1). It is located at the Tapajós Domain of the Tapajós-Parima Province (2.03 to $1.86 \mathrm{Ga})$ and in 
the west region of the Central Amazonian Province (1.90 to 1.86 Ga; [42]). The Juruena Mineral Province (JMP) is the north part of the Rio Negro-Juruena Province [43,44] and is located between the Tapajós-Parima (2.03-1.88 Ga) and Rondônia-Juruena (1.85 to $1.54 \mathrm{Ga}$ ) geochronological provinces [5,45].

Scandolara et al. (2017) [53] proposed a new tectonic model for the southern part of the Amazonian craton, in which the Juruena accretionary orogenic belt (ca. 1.81 to $1.51 \mathrm{Ga}$ ), including the Rio Negro-Juruena and Rondonian-San Ignácio or RondôniaJuruena geochronological provinces, collided with the Tapajós Domain at ca. 1.69 to $1.63 \mathrm{Ga}$. The Juruena magmatic arc was reinforced as of the Andean-type. The Alta Floresta Domain, in this model, comprises the basement of the Juruena magmatic arc, corresponding to the Paleoproterozoic Tapajós magmatic arcs, which was intruded upon and covered by the Juruena arc geological units.

Santos et al. (2008) [42] proposed the tectonic evolution of the Tapajós Domain starting with oceanic magmatism (Tapuru), followed by an island arc accretion (CuiúCuiú), two subsequent continental magmatic arcs (Cumaru and Creporizão), another island arc (Tropas) and a later continental magmatic arc (Parauari), all of them formed by NW-SE-trending subduction and continental accretion episodes. Some of these arcs are not distinguished on geologic maps, and the sutures of the accretionary events or juxtaposition of island arc to continental margins are not identified, except the inferred locations of the collages between the Tapajós-Parima and the Central Amazonian provinces and the Rondônia-Juruena and Tapajós-Parima provinces.

Nevertheless, the limits and, in part, the orientation of the geochronological provinces of the Amazonian Craton are distinct according to different authors [5,43-45], which brings inaccuracies and even their questionable existence, since no evidence for suture zones nor deformed and metamorphosed oceanic sequences are observed in the collage zones. Furthermore, some orogenic geological units are continuous across distinct considered accreted terrains and provinces. The missing of several geological attributes for these interpretations has stimulated a heated debate on the Amazonian Craton tectonic evolution [54-58].

Volcanic units in the Tapajós Domain were identified as part of all magmatic arcs by [42], except in the later Parauari arc. These authors considered the largest volume of well-preserved volcanic units, with ages similar to those of the Parauari rocks, a postorogenic cover. These volcanic units are named Uatumã Supergroup in the Tapajós Domain and Teles Pires Group in the Rondônia-Juruena Province, both related to post-orogenic to intracratonic A-type magmatism [3,44,45]. However, the ca. 1.89-1.87 Ga and ca. 1.97 to $1.95 \mathrm{Ga}$ subduction-related calc-alkaline andesites to rhyolites have been separated from A-type rocks in several localities in the Tapajós Domain [3,15,46,56,59-61] and the Juruena Domain $[53,62,63]$.

An alternative interpretation for the tectonic environment of the TMP, based on extensive fieldworks, geochemistry, paleoenvironment, and geophysics, proposed that the Archean basement of the Carajás Province extends under the Paleoproterozoic volcanic and sedimentary units, probably beyond the west limit of the province $[36,54,64,65]$. Inherited zircon grains in the TMP granites with $\mathrm{U}-\mathrm{Pb}$ ages of 2480 to $2859 \mathrm{Ma}$ [42] and their Sm-Nd $\mathrm{T}_{\mathrm{DM}}$ ages (ca. 2.5-2.9 Ga) and eNd values $(-0.2$ to -11.3$)[4,66]$ reinforce the contribution of an Archean crust at the TMP, in addition to a dominant mantle source accreted at about 2.2 Ga. According to this alternative tectonic model, the formation and evolution of the Paleoproterozoic units occurred by a long-lived (almost $220 \mathrm{Ma}$ ) ocean-continent orogeny with an approximately E-W-oriented subduction, dipping to north, which originated at least two partial overlapped continental magmatic arcs (Tapajonic arcs I and II) from ca. 2.1 to $1.87 \mathrm{Ga}$. During this evolution, intense uplift, erosion and rifting, and pull-apart basin formation contributed to preserving the volcanic units.

In this model, the occurrence of younger calc-alkaline associations (ca. 1.88 Ga) in the São Félix do Xingu region was considered a result of the sink of the oceanic crust after a flat-subduction stage [56,59]. The deep character of the E-W-trending structures, inferred 
from the residual magnetic field, reveals the most likely direction of the mobile belt and older magmatic arcs generated in the southern part of the Amazonian Craton [54].

Additionally, aerogeophysical and gravimetric data and the modeled depth of the $\mathrm{MOHO}$ discontinuity reveal deep regional $\mathrm{E}-\mathrm{W}$-oriented crustal high- and low-structures under the volcanic units, besides a system of NW-SE and NE-SW-trending major brittle faults, which host A-type granite intrusions [54]. Major tectonic blocks defined by these structures appear to control post-Paleoproterozoic uplifts and the erosion of the supracrustal units, in part due to the Mesoproterozoic collision of the N-S-oriented Araguaia belt at the east border of the Amazonian Craton.

\section{Geological Framework}

\subsection{Tapajós Mineral Province (TMP)}

In the TMP, to the east of the Tapajós river, the exposed crustal level is gradually shallower. Volcanic units and associated volcanic epiclastic, fluvial, and lacustrine sequences extend eastwards until the São Félix do Xingu area (Figure 2), where the Archean units of the Carajás Province outcrop [46].
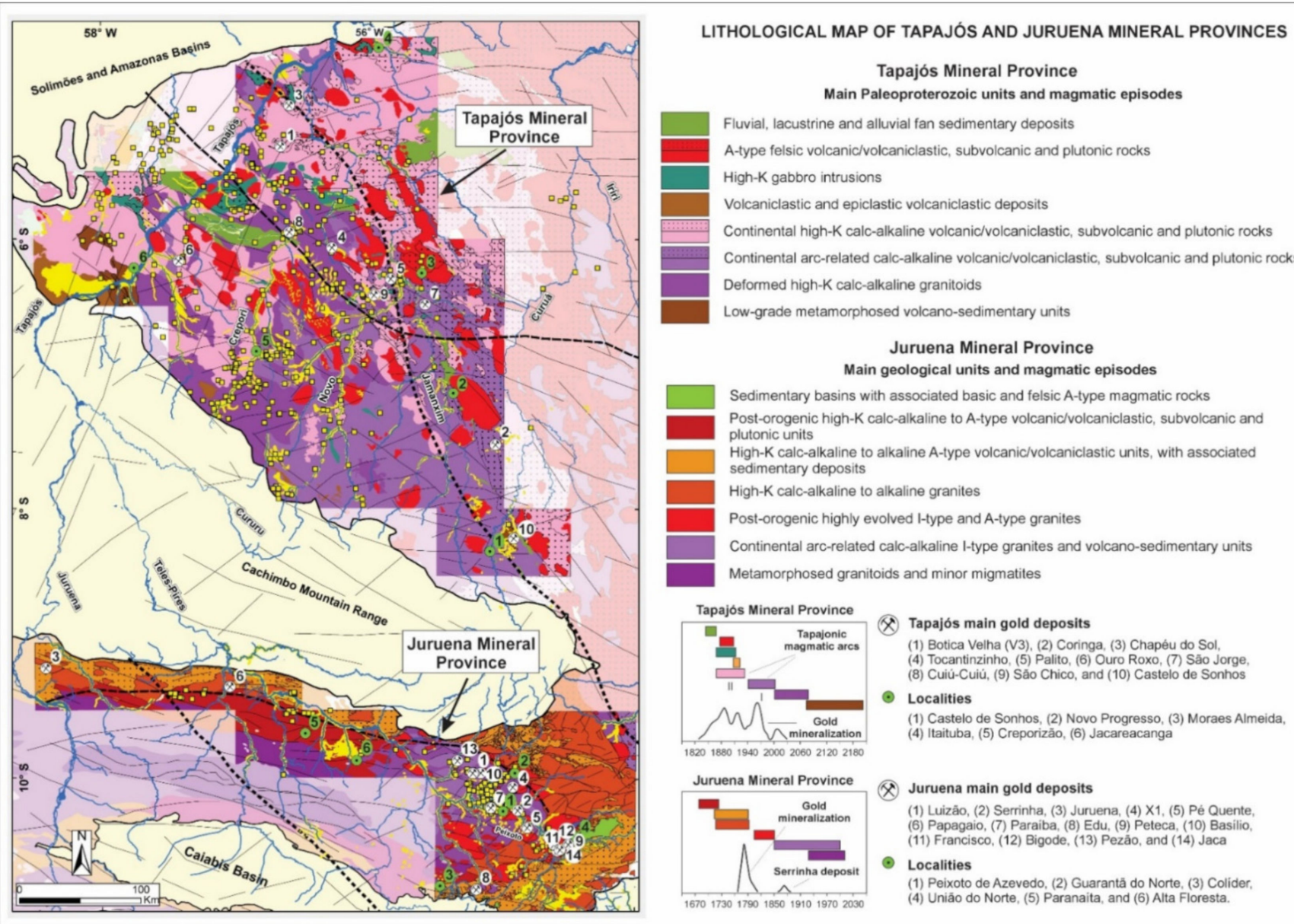

Figure 2. Lithological map of the Tapajós and Juruena mineral provinces in the Amazonian Craton, showing the location of the main gold deposits and occurrences, main magmatic events and gold mineralization. Yellow-filled squares represent gold occurrences, green-filled squares the copper occurrences, short trace lines limit the Tapajós Province of [5], and the long traces limit of [43]. Light-color geologic base map by [45], detailed lithologic map of TMP of [61] and the JMP map by [58].

In the TMP, fault-controlled gold occurrences are mainly granite-hosted, with less common occurrences in volcanic/volcaniclastic rocks and few in sedimentary sequences. However, gold associated with base metal is also recognized in several volcanic and sedimentary cover areas, particularly where the erosion of the upper sedimentary units 
exposed the volcanic sequence. This indicates that the TMP delimitation is not defined by metallogenetic controls but by the occurrence of granite-hosted gold mineralized veins, more easily mined by artisanal prospectors.

The main TMP geological units $[5,8,44]$ are represented by a ca. 2.1 Ga volcanosedimentary sequence of the Jacareacanga Group, and the Cuiú-Cuiú tonalites, granodiorites and subordinated granites (ca. 2.01 Ga), Cumuru and Creporizão granodiorites and granites (ca. 1.97 to $1.95 \mathrm{Ga}$ ), Rio das Tropas tonalites (ca. $1.90 \mathrm{Ga}$ ), and Parauari granodiorites and granites (ca. $1.89 \mathrm{Ga}$ ) (Figure 2).

The Paleoproterozoic volcanism in south Amazonian Craton, originally named Uatumã, was restricted to ca. $1.88 \mathrm{Ga}$. However, in the outcrop area of this unit, rocks formed in several magmatic events, including ca. 2.0 to $1.87 \mathrm{Ga}$ calc-alkaline and ca. $1.88-1.87 \mathrm{Ga}$ A-type volcanic and volcaniclastic rocks, and associated diorites to granites and porphyries, A-type granites and porphyries also occur. However, many of these orogenic intermediate to felsic volcanic sequences, including basaltic andesite, andesite, dacite, rhyodacite, rhyolite, and volcaniclastic rocks, with ages around 2.0 Ga (e.g., Vila Riozinho Formation [3], 1.97 to $1.95 \mathrm{Ga}$, and ca $1.88 \mathrm{Ga}[22,26,55,67-69]$, are not individualized on geological maps (Figure 2).

As originally defined, we consider that the Uatumã magmatic event comprises Atype ignimbrites and rhyolites, including the Moraes Almeida Formation (ca. 1.88 Ga; [3], large NW-SE- and NE-SW-striking felsic dikes, and A-type granites, grouped as the ca. $1.87 \mathrm{Ga}$ Maloquinha Intrusive Suite in the Tapajós to Xingu areas. The Maloquinha A-type granites are relatively common [5], but some intense K-metasomatized shallow-emplaced calc-alkaline rhyodacitic to granitic stocks have also been sometimes incorrectly included in this suite. Paleoproterozoic fluvial and marine units and several mafic intrusions with ages ranging from Paleoproterozoic to Neoproterozoic also occur in the TMP.

As summarized by [8] in the west and south part of the TMP, supracrustal sequences and granites are less abundant, predominating diorite, tonalite, and granodiorite, usually with mafic xenoliths, dikes and intrusions of basic and intermediate rocks. Migmatites are also identified. Commonly these units were deformed by faults and underwent hydrothermal alteration. The supracrustal units undergone metamorphism under zeolite to prehnite-pumpellyite facies, rarely reaching greenschist facies conditions.

\section{The ca. 2.1 to 1.88 Ga Orogenic Volcanic Rocks in the TMP}

The orogenic volcanic rocks from different events compose at least three extended magmatic series in the Tapajós Domain and one younger in the Juruena Domain, with geochemical compositions and petrogenetic signatures compatible with Andean-type arcrelated granitoids and volcanic rocks. Moreover, two intraplate A-type granite events are registered, the oldest at TMP and a younger in the Juruena (Figures 1 and 2). The erosional level of the Juruena Mineral Province is relatively deeper, exposing metamorphic units at the central region of the province, with volcanic and volcaniclastic units essentially preserved at the north, south and east areas.

The original area of the ca. 2.1 to $1.88 \mathrm{Ga}$ orogenic volcanic rocks, which vary from andesite basalts to rhyolites, predominating felsic rocks, associated intrusive rocks, and the A-type volcanic and intrusive units, is estimated up to $1,500,000 \mathrm{~km}^{2}$ [60]. Due to the lack of access, weathering, sparse outcrops and similar macroscopic and petrographic aspects of volcanic and volcaniclastic deposits, the distinction of units from different events, as well the volcanic/volcaniclastic facies, is challenging. Only with intensive geochemistry and geochronology, new volcanic events, volcanic calderas, and eruptive and magmatichydrothermal centers have been identified $[15,68,69]$.

The lava flows, ignimbrites, pyroclastic and volcaniclastic/epiclastic deposits, dikes, remains of volcanoes, volcanic domes, and associated porphyries, granophyres, granophyric and plutonic granitoids, usually porphyritic, are geologically and petrographically heterogeneous $[7,38-40]$. 
The supracrustal sequences at the Tapajós, particularly those from the last orogenic event, reveal remarkably well-preserved volcanic textures and structures from deformation and metamorphism [70]. Large nested volcanic calderas (up to $50 \mathrm{~km}$ in diameter) over or close to large E-W lineaments have been identified in the Tapajós and Xingu areas $[15,46,71]$, as well in the Juruena Domain [62,72].

Extensive eruptions controlled by large NW-SE and NE-SE brittle structures host ca. 1.87 Ga A-type magmatism [60]. However, the stratigraphy, age and distribution of the volcanic centers, and the identification of calderas from different magmatic events in the Tapajós and Juruena domains are only beginning.

In the TMP, the calc-alkaline volcanic sequences include some large ca. 1.89-1.87 Ga nested ash-flow caldera complexes [15,73]. The pre-caldera units are composed of flows and dikes of basaltic andesite and andesite, rhyodacite, dacite, rhyolite, and ignimbrites. Latite, trachyandesite, ash- and crystal tuffs, and acid to intermediate hyaloclastites are also present. The syn-caldera units consist of several large ignimbrite and ash-flow deposits with subordinated rhyolite flows. The post-caldera units include mainly rhyolites and ignimbrites, which form composite volcanoes and domes along with rings and within the calderas. Tuffs, epiclastic sandstone and lacustrine sediments compose the intracaldera deposits. Granophyric stocks and rhyolitic and rhyodacitic porphyry dikes crosscut the volcanic sequence. These volcanic units are interfingered and are partially covered by Paleoproterozoic lacustrine, fluvial and marine sedimentary sequences.

Inferred ca. $1.99 \mathrm{Ga}$ volcanic calderas with similar lithological sequences are also proposed in areas at the north of the TMP, where typical low- to high-sulfidation gold mineralization is overprinted by porphyry-type $\mathrm{Cu}-\mathrm{Mo}$ mineralization associated with sheeted felsic porphyry dikes [22]. Several rhyolitic domes (ca. 1.97-1.98 Ga) host low- and intermediate-sulfidation mineralization in the south portion of the TMP [26,34].

\subsection{Juruena Mineral Province}

According to [5], the JMP is the area with the majority of gold mineralization (Alta Floresta and Peixoto de Azevedo regions). The JMP mainly comprises Paleoproterozoic oxidized calc-alkaline, medium- to high-K, peraluminous to metaluminous I-type granites, volcanic and volcano-sedimentary sequences, with subordinate later A-type granites and volcanic rocks (Figure 2). The JMP units are grouped into: (1) 2.81-1.99 Ga deformed granitic basement; (2) 1.97-1.87 Ga felsic I-type granites, volcanic and volcanosedimentary units; (3) 1.78-1.77 Ga highly evolved I-type post-orogenic and A-type and volcanic, sub-volcanic, and volcano-sedimentary sequences; and (4) ca. 1.37 Ga clastic sedimentary sequence.

The basement of the supracrustal units consists of tonalitic to granitic gneiss and migmatites, intruded by ca. $1.97 \mathrm{Ga}$ deformed and foliated calc-alkaline monzogranite to tonalite [11]. The SHRIMP U-Pb zircon crystallization ages of the tonalite gneiss range from $1992 \pm 7 \mathrm{Ma}$ [74] to $1984 \pm 7 \mathrm{Ma}$ [11]. The granitic to gneiss exhibit a Pb-evaporation single zircon age at $2816 \pm 4 \mathrm{Ma}$. Moreover, the ca. $2.0 \mathrm{Ga}$ arc-derived volcano-sedimentary sequence (e.g., Serra Formosa Formation) is composed of volcaniclastic feldspathic-sandstone, arkose, feldspathic wacke, lithic-sandstone and minor conglomerate [23,58,63,75].

Continental magmatic arc magnetite-bearing granite stocks, emplaced in katazonalmesozonal to epizonal crustal level, are intrusive in the basement units and the volcanosedimentary sequences. Associated arc-related calc-alkaline dacitic to rhyolitic volcanic units are also present. Such units comprise the Pé Quente monzonite, monzodiorite, and quartz monzonite (ca. $1.97 \mathrm{Ga}$; $23,63,75]$; Novo Mundo syenogranite and monzogranite ca. 1.96-1.97 Ga; [11]; Flor da Mata and Aragão syenogranite and monzogranite (ca. 1.93 Ga; [75], and Guarantã adakite-like granodiorite and tonalite (1.90-1.89 Ga; [63,76,77]. A 1.93 Ga metamafic-metaultramafic unit composed of phlogopite schist is restricted to the Serrinha do Guarantã vein-type gold deposit. Excluding the Flor da Mata granite, all the others host hydrothermal gold mineralization. 
Between ca. 1.87 and $1.77 \mathrm{Ga}$, large volumes of calc-alkaline, oxidized, peraluminous to metaluminous granite magmas were produced into the syn-orogenic onset [58,74,77-79]. Such event is represented by the Nhandu Granite (ca. $1.87 \mathrm{Ga}$; [11,80]), hornblende- and biotite-bearing granite and granodiorite from the Matupá Suite (ca. 1.87-1.86 Ga; [76,77,81]), União Granodiorite (ca. 1.85 Ga; [23,75]), Peixoto Granite (ca. 1.79 Ga; [11]) and volcanic rocks of the Colíder Group (ca. 1.81-1.78 Ga; [58,62,79,80,82]. The Colíder Group comprises rhyolite, rhyodacite, quartz trachyte, ignimbrites, laminated ash-tuffs, epiclastic rocks, and minor andesite [74,77]. These units are often crosscut by 1.79-1.78 Ga mafic to felsic dikes emplaced in variable crustal levels, including gabbro, diabase, andesite, dacite, and rhyolite $[23,29,62,79]$.

Post-orogenic and anorogenic granites, porphyries, and volcanic rocks of the Teles Pires Intrusive suite (ca. 1.78-1.75 Ga; [5,58,74,77,83]) represent the latest magmatic event that took place in the JMP. This magmatic event includes equigranular to porphyritic granite, microgranite, granophyres, porphyries, rhyolite and rhyolitic lavas, which exhibit Sm-Nd TDM ages from 2.28 to $1.94 \mathrm{Ga}$ and $\varepsilon \mathrm{Nd}_{(\mathrm{t})}$ between -3.4 and +3.0 ; suggesting Paleoproterozoic sources with an important crustal component.

\section{Gold Mineralization: Distribution and Genesis}

Until the final of the 70's decade, gold was mined in alluvial (recent and TertiaryQuaternary paleoplacers) and eluvial deposits at the Tapajós, with rare known occurrences of primary mineralization [84]. Due to the geological studies by the Geological Survey of Brazil in the Amazonian Craton in the 90's years, [85] identified the relationship of the magmatism with gold lode and stockwork mineralization at the Tapajós. These authors proposed its generation in an intermediate crustal level between those of epithermal and mesothermal environments, and proposed potential to porphyry-type gold occurrences.

Santos et al. (2001) [1], in a review concerning of the Paleoproterozoic gold mineralization at the Tapajós and Alta Floresta domains, defined the following deposit types: (1) orogenic, metaturbidite-hosted disseminated and quartz-pyrite veinlets in ductile shears zones in the lower greenschist facies of the Jacareacanga Group; (2) orogenic, mesozonal, hosted by magmatic arc-related plutonic rocks, disseminated in mafic xenoliths and roof pendants and as pyrite-quartz-carbonate veins with up to $50 \mathrm{~g} / \mathrm{t} \mathrm{Au}$ and $1.5 \% \mathrm{Cu}$ in ductile-brittle shear zones of the Cuiú-Cuiú and Tropas units; (3) intrusion-related or intrusion-centered (as proposed by [86]) epizonal quartz and quartz-pyrite veins and pyrite disseminations in extensional brittle faults, considered as similar to the Koreantype gold deposits; (4) intrusion-related epizonal (as defined by [87]), forming disseminated/stockwork mineralization, sharing some similarities with porphyry-type deposits (e.g., Serrinha deposit; $[19,20])$; and (5) paleoplacers, predominantly in Paleoproterozoic conglomerates.

According to these authors, most gold deposits were described as granite-hosted and attributed to intrusion-related processes in the TMP, with few occurrences associated with orogenic and only one as an epizonal intrusion-related mineralization. The orogenic gold mineralization timing was uncertain, but it was considered possibly similar to intrusionrelated mineralization [1]. The ca. $1.87 \mathrm{Ga}$ A-type Maloquinha granites were considered the source for the mineralizing fluids or the thermal engine to hydrothermal fluid circulation, and the age of mineralization was defined as 1874 to $1860 \mathrm{Ma}$. In the JMP, the Serrinha deposit was characterized as the unique typical intrusion-centered disseminated gold deposit [20], but its relationship with the porphyry copper-gold type deposits was considered unclear. Except for this, none of the other gold occurrences in the JMP were classified as orogenic or intrusion-related by [1].

The discovery by Rio Tinto of a very-well preserved high-sulfidation mineralization [12-16] in remains of ring-volcanoes associated with nested ash-flow calderas in the TMP suggested a new potential for mineral exploration. As the high-sulfidation mineralization is genetically related to magmatic-hydrothermal fluids exsolved from more oxidized magmas, which are also associated with $\mathrm{Cu}-\mathrm{Au}$ and $\mathrm{Cu}-\mathrm{Mo}$ porphyry deposits $[21,88]$, 
the mineral potential was extended to large-scale gold and base metals epithermal and porphyry-like deposits in the Tapajós and Juruena provinces.

In a summary of the geology and gold metallogenesis of the TMP, [8] reinterpreted all gold deposits and prospects as orogenic, predominantly deep-emplaced (mesozonal) deposits. These authors did not consider for this interpretation the common presence of copper sulfides (sometimes in high-grades), lack of arsenopyrite, ankerite and siderite, hydrothermal alteration types and zoning, and stable-isotope evidence of magmatic-derived components (e.g., fluids and sulfur). In the following years, junior and major mining companies adopted the orogenic gold deposit genetic model for the gold exploration, and several small deposits represented by discontinues and irregular quartz-pyrite and quartz-base metal sulfide veins were discovered. Few academic studies were developed to understand the genesis of this mineralization type, considered as orogenic and disconnected of the magmatic evolution $[9,10]$.

More recently, academic and mine company works enabled the discovery of many epithermal (high-, intermediate-, and low-sulfidation) gold targets, some of them with $\mathrm{Au}-\mathrm{Ag}-\mathrm{Pb}-\mathrm{Zn}-\mathrm{Cu}$, as well porphyry-like $\mathrm{Cu}-\mathrm{Au}-\mathrm{Mo}$ mineralization, in both provinces. Similar processes in the mineral exploration occurred in the JMP, with comparable results. The relationship among gold vein, disseminated and stockwork mineralization and magmatic events [8] highlights the importance of constraint the gold metallogenesis related to magmatic-hydrothermal systems.

\subsection{Gold Deposits in the Tapajós Mineral Province}

\subsubsection{Epithermal Au Deposits}

The main epithermal $\mathrm{Au}-(\mathrm{Ag})$ mineralization is recognized in volcanic-hosted gold deposits, prospects and occurrences in the TMP, such as Botica Velha (V3), Bom Jardim, Doze de Outubro, Chapéu de Sol, Coringa, Pista, Fofão, Mato Velho, Davi, Joel and São Chico (Table S1, Supplementary Materials), as well as several occurrences in the Xingu and Iriri areas. These targets have been classified as high-, intermediate-, and low-sulfidation deposits due to their distinct hydrothermal alteration types, physicochemicalparameters and ore mineralogy. The prominent examples of each deposit type are described below.

High-Sulfidation Epithermal Au-(Ag) Deposits

The Botica Velha Au-(Ag) deposit (Figure 3A) was the first Paleoproterozoic highsulfidation epithermal deposit identified in the Amazonian Craton and Brazil. It contains $30 \mathrm{t}$ of gold at a maximum of $4.5 \mathrm{~g} / \mathrm{t} \mathrm{Au}$, besides anomalous silver and minor $\mathrm{Cu}, \mathrm{Zn}$, and Mo [14]. 

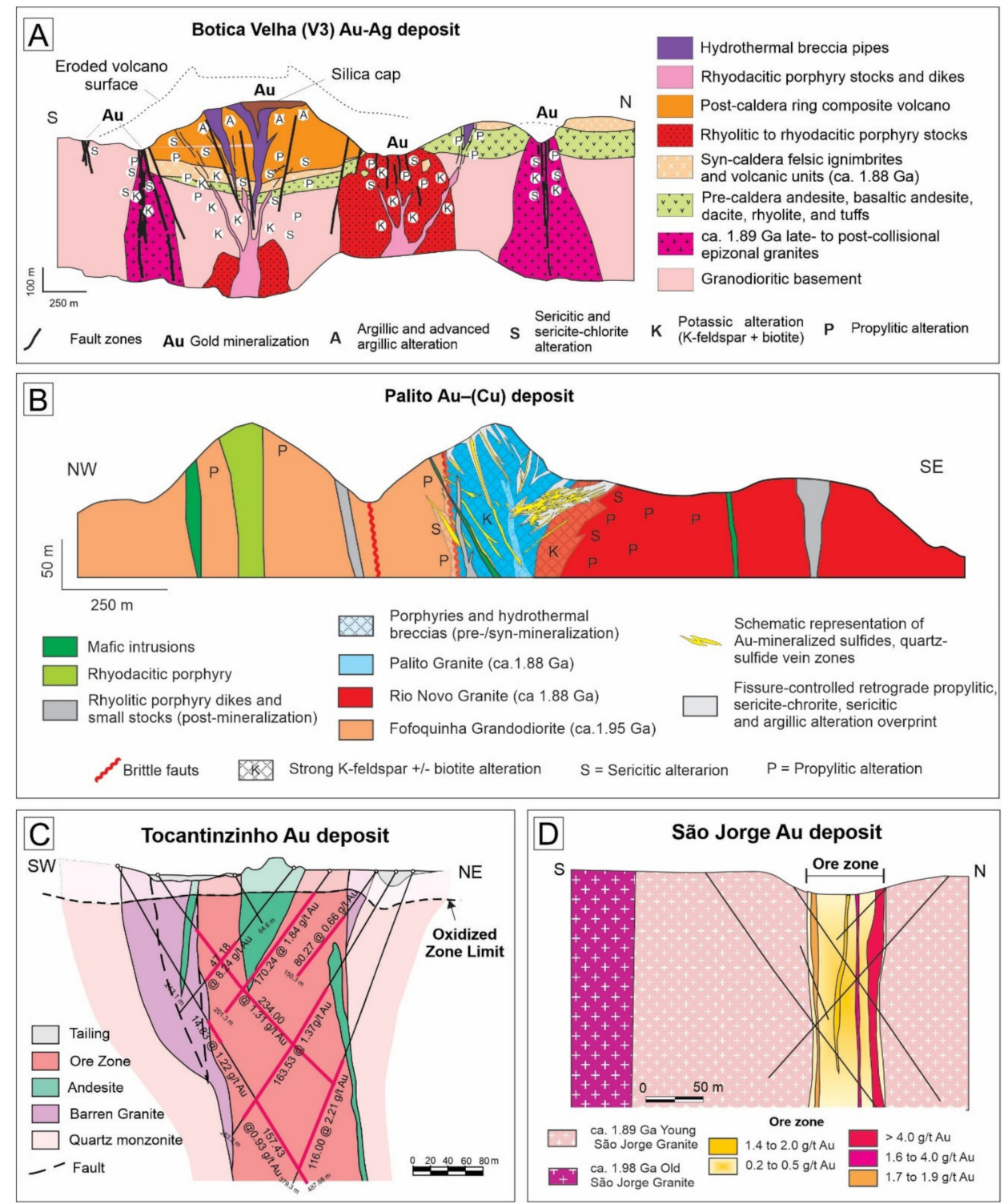

Figure 3. Cross-sections of the gold-(polymetallic) deposits of the Tapajós Mineral Province. (A) Schematic cross-section of the Botica Velha (V3) high-sulfidation gold-silver epithermal deposit [15] (\#1 in Figure 2); (B) Schematic cross-section of the Palito gold-(copper) porphyry deposit (\#5 in Figure 2). The scale of de gold-mineralized veins and associated sericitic alteration are exaggerated to represent the style of structure-controlled mineralization (this study); (C) Cross-section of the Tocantinzinho gold porphyry-like deposit [89] (\#4 in Figure 2); (D) Cross-section of the São Jorge structurally-controlled granite-hosted gold deposit [90] (\#7 in Figure 2).

Intermediate to felsic lava flows and volcaniclastic rocks, related to the evolution of a nested caldera complex, host the Au-Ag mineralization [12,13,15]. In the pre-caldera stage, stratovolcanoes with a basal andesite (Figure 4A,B) sequence and associated ignimbrite and rhyolitic lava flows were formed. The sin-caldera stage encompasses a large cover of crystal-, lapilli- and ash-tuffs (Figure 4C), ignimbrites and volcanic breccias that resulted in collapse into the magmatic chamber. A late-stage, related to intracaldera epiclastic deposits and annular, radial, or internal volcanoes, comprises lava flows, volcaniclastic rocks, and rhyolitic resurgent domes, similar to those described by [91]. The Au-Ag mineralization occurs in inverted cone-shaped hydrothermal breccias formed in an annular rhyolitic volcano of the post-caldera stage $[12,13,15]$. Hydrothermal alteration zones flare upwards and are spatially related to calc-alkaline rhyolitic and rhyodacitic porphyries stocks (ca. 1.87-1.89 Ga). 

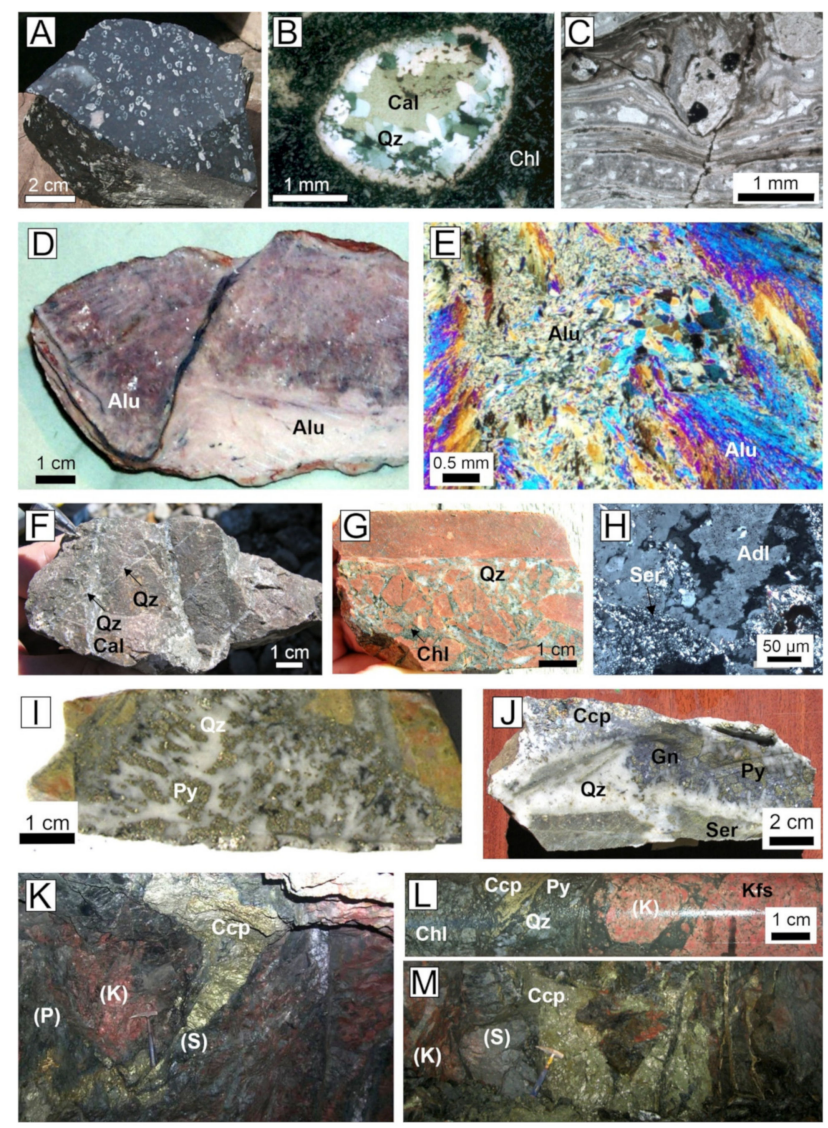

Figure 4. Aspects of the gold-(polymetallic) deposits of the TMP and their host rocks. (A) Amygdaloidal andesite with propylitic hydrothermal alteration form outer zones of the Botica Velha (V3) high-sulfidation gold mineralization; (B) Detail of an amygdule in (A) e, filled by quartz druses and later calcite, showing the very well-preserved state of volcanic rocks from the TMP; $(\mathbf{C})$ Laminated rhyolitic tuff (transmitted light; parallel polarizers); (D) Pink coarse-grained alunite branching vein and later white, fine-grained alunite; (E) Detail of (d), showing the coarse-grained alunite branching replaced by fine-grained alunite (transmitted light; crossed polarizers); (F) Porphyritic rhyolite that hosts the Coringa low- to intermediate-sulfidation mineralization crosscut by quartz and calcite veinlets; (G) Rhyolite cut by hydrothermal breccia vein cemented by quartz, chlorite and small amounts of pyrite (Coringa deposit); (H) Adularia that replaced igneous feldspar crystals from adularia-sericite halo associated with the Coringa gold-polymetallic mineralization. Note the dissolution vugs of igneous feldspar replaced by adularia and well-formed small druses of adularia; (I) Gold-mineralized epithermal quartz-pyrite vein of the Coringa deposit; (J) Gold-mineralized epithermal quartz-pyritegalena-chalcopyrite vein of the Coringa deposit; (K) Deformed massive gold-rich chalcopyrite vein with associated pyrite and minor bornite hosted by the Palito Granite affected by potassic (strong red-color), propylitic and sericitic alteration; (L) Hydrothermal breccia with a quartz-sulfide-chlorite matrix (dark-colors) and rounded fragments and veinlets of chalcopyrite, hosted by the potassic altered Palito Granite. Note quartz-sulfide gold mineralized vein; (M) Sulfide-rich sulfide zones from the Palito $\mathrm{Au}-(\mathrm{Cu})$ porphyry deposit. Mineral abbreviation after [92]. $(\mathrm{K})=$ potassic alteration; $(\mathrm{S})=$ sericitic alteration; $(\mathrm{P})=$ propylitic alteration.

The Au-Ag mineralization is spatially related to the advanced argillic (quartz-alunite and pyrophyllite) alteration. Ore minerals are pyrite and minor covellite, bornite, enargiteluzonite, famatinite, tiemannite, tennantite-tetrahedrite, galena, chalcopyrite, sphalerite, aguilarite, native silver, copper, and gold. Native gold occurs mainly in the pyrophylliterich matrix and as fine inclusions in covellite $[13,15]$.

The $\delta^{34} \mathrm{~S}$ and $\delta^{18} \mathrm{O}_{\mathrm{SO} 4}$ values of alunite are within that of reference for magmatichydrothermal alunite [15]. Temperatures, estimated from oxygen isotopes in alunite 
$\mathrm{SO}_{4}-\mathrm{OH}$ and from sulfur isotope composition of pyrite-alunite pairs, range from 130 to $420{ }^{\circ} \mathrm{C}$. Calculated $\delta \mathrm{D}_{\mathrm{H} 2 \mathrm{O}}$ and $\delta^{18} \mathrm{O}_{\mathrm{H} 2 \mathrm{O}}$ values for the hydrothermal fluids equilibrated with alunite (Figure 5A) suggest mainly a magmatic origin [15]. Hydrothermal fluids in equilibrium with deeper sericite have an $\mathrm{O}-\mathrm{H}$ composition typical of magmatic brines, including vapor phases. A minor contribution of seawater and meteoric waters with a high evaporation rate is admissible for the low-temperature alunite, pyrophyllite, and kaolinite formation [40]. Collectively, the stable isotope $(\mathrm{O}, \mathrm{H}, \mathrm{S})$ characteristics of the Paleoproterozoic fluids at the Botica Velha (V3) deposit are similar to those from Mesozoic and recent epithermal high-sulfidation deposits described in the Andes, Western USA, and Indonesia $[15,39,40]$.

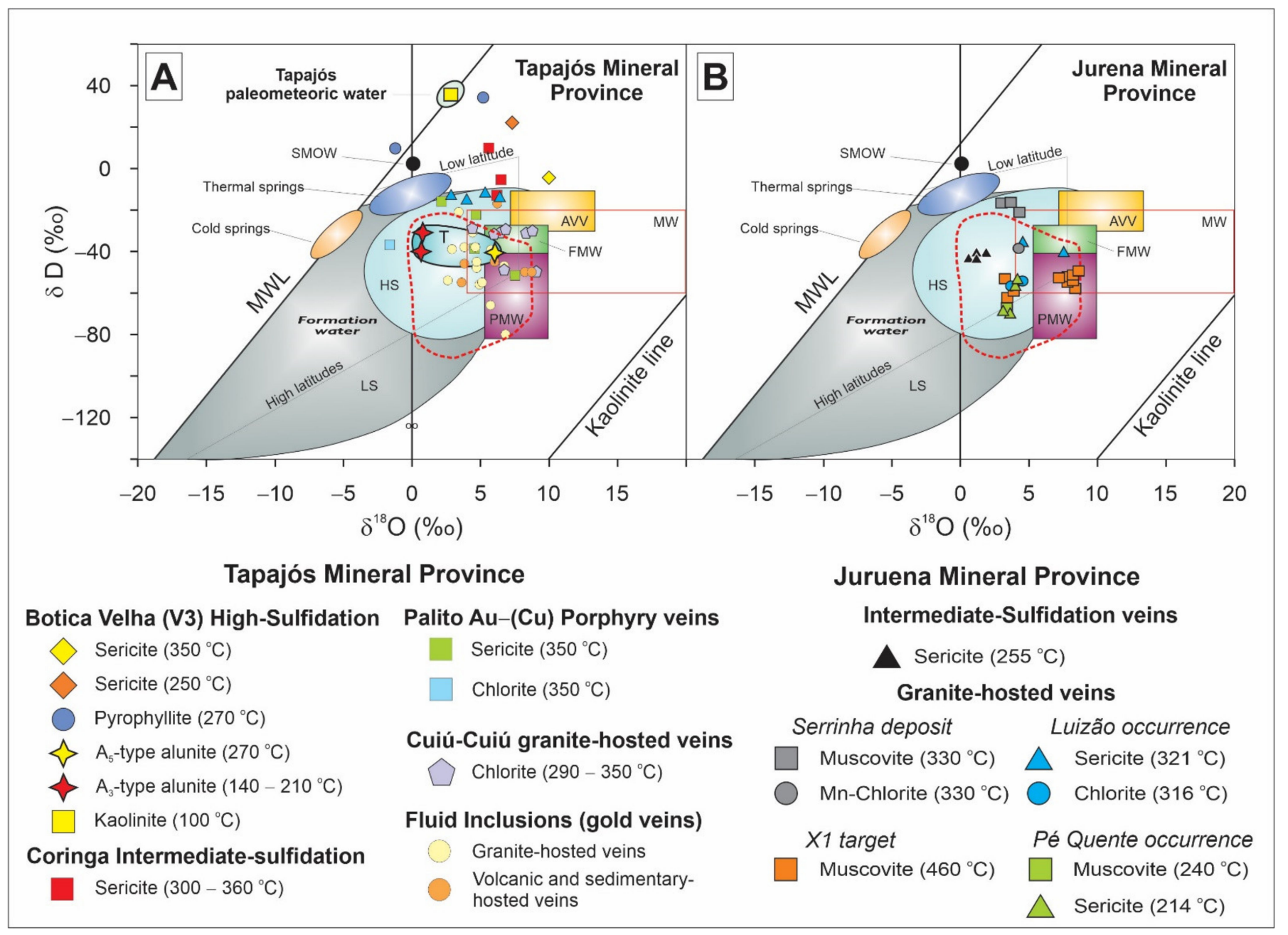

Figure 5. Calculated oxygen and hydrogen isotope composition of the hydrothermal fluids in equilibrium with minerals representative of the magmatic-hydrothermal deposits and prospects in the TMP (A) and JMP (B). Alunite field based on [93]; PMW = primary magmatic water [94]; VW = volcanic water [95]; epithermal deposit fluids [96,97] cold and thermal springs [98]. The dashed red line discriminates potassic (inside the magmatic water field) and sericitic (outside the magmatic water field) alteration of porphyry mineralization [99]. HS = Field of high-sulfidation hydrothermal fluids; LS = Low-sulfidation fluids, and $\mathrm{T}=$ Alunite of the $1.87 \mathrm{Ga}$ Tapajós high-sulfidation fluid. Data source: [this paper and $[8,15,20,35,62,76,100,101]]$.

Nine ${ }^{40}$ Ar $-{ }^{39}$ Ar spectra for alunite yield ages between $1869 \pm 2 \mathrm{Ma}$ and $1846 \pm 2 \mathrm{Ma}$. The high-temperature maximum age (ca. $1.87 \mathrm{Ga}$ ) was interpreted as the timing of the magmatic-hydrothermal alunite formation in the high-sulfidation deposit [15]. A ca. 1805 Ma plateau age may reflect post-crystallization resetting, likely related to N-S and 
NW-SE faults. After that, a long period of thermo-tectonic stability prevailed at the TMP, until the deposit unroofing at $51.3 \pm 0.1 \mathrm{Ma}$ [15].

Quantitative analyses for active and noble $(\mathrm{He}, \mathrm{Ar}, \mathrm{Ne})$ gases in fluid inclusions and within the alunite crystal structure confirmed a remarkable Ar retention in alunite [16]. Vapor-rich fluid inclusions trapped in alunite have high $\mathrm{CO}$ and $\mathrm{H}_{2}$ contents and $\mathrm{CO}_{2} / \mathrm{CH}_{4}$ (12.8) and $\mathrm{H}_{2} \mathrm{~S} / \mathrm{SO}_{2}$ (2.3) ratios typical for magmatic-hydrothermal fluids. The presence of a magmatic He component was possibly derived from the primitive and relatively undegassed mantle. Overall, the $\mathrm{N}_{2}-\mathrm{Ar}-\mathrm{He}$ composition of the Tapajós alunite is similar to that of other high-sulfidation epithermal deposits [16,102].

\section{Intermediate-Sulfidation Epithermal $\mathrm{Au}-\mathrm{Ag}-(\mathrm{Cu}-\mathrm{Pb}-\mathrm{Zn})$ Deposits}

The Coringa $\mathrm{Au}-\mathrm{Ag}-(\mathrm{Cu}-\mathrm{Pb}-\mathrm{Zn})$ deposit, located in the southeasternmost region of the TMP, has proven and probable reserves of 768,600 $\mathrm{t} @ 6.49 \mathrm{~g} / \mathrm{t}$ Au $[103,104]$ and produced $10 \mathrm{t}$ of gold from alluvial and primary sources until 1991. A cluster of other prospects (e.g., Mato Velho, Serra, Demétrio, Pista, Fofão, Domingos) occurs nearby the Coringa deposit.

The Coringa deposit is hosted in faults and fractures in rhyolite domes associated with andesite lava flows and volcaniclastic fluxes with ignimbrites, volcanic agglomerates, and lapilli- and ash-tuffs [26]. Radial and annular hydrothermal breccia dikes are common. Rhyolite domes comprise cogenetic black, porphyritic rhyolite $(1967 \pm 6.6 \mathrm{Ma}$ to $1975 \pm 5.3 \mathrm{Ma}$; SHRIMP IIe U-Pb in zircon; [26]; Figure 4F) and reddish flow-banded rhyolite with lithophysae (1.966 $\pm 22 \mathrm{Ma}$, SHRIMP IIe U-Pb in zircon; [26]). A magnetic pyroclastic facies $\left(1990 \pm 21 \mathrm{Ma}\right.$ to $1940 \pm 19 \mathrm{Ma}$; LA-ICP-MS U-Pb; Sm-Nd T $\mathrm{DM}_{\mathrm{DM}}$ ages $=2.38$ and $2.42 \mathrm{Ga} ; \varepsilon \mathrm{Nd}_{(\mathrm{t})}=2.1$ to 3.2) was recognized by [105].

In the Coringa area, porphyritic alkali feldspar granite and quartz monzonite porphyry (1980 $\pm 6.6 \mathrm{Ma}$ to $1998 \pm 6 \mathrm{Ma}$; [26,105]) and older granites of the volcanic sequence basement $\left(2123 \pm 86 \mathrm{Ma}\right.$ and $2023 \pm 30 \mathrm{Ma}$ with $\mathrm{Sm}-\mathrm{Nd} \mathrm{T}_{\mathrm{DM}}$ ages = $2.34 \mathrm{Ga}$; $\varepsilon \mathrm{Nd}_{(\mathrm{t})}=-1.91$; [26]) occur. Intrusive porphyry (1959 $\left.\pm 5.5 \mathrm{Ma} ; 1963 \pm 15 \mathrm{Ma}\right)$, shallowemplaced granites with miarolitic texture $(1959 \pm 25 \mathrm{Ma})$, and granodiorite $(1955 \pm 19 \mathrm{Ma})$ intercept the volcanic sequence [26]. Volcanic rocks and intrusive porphyries are oxidized, magnesian, calc-alkaline, and have a high-K to shoshonite affinity [26,105].

Shallow-emplaced granites, porphyries, and volcanic-volcaniclastic units were brecciated (Figure 4G) and underwent intense pervasive and fracture-controlled hydrothermal alteration, which evolves from potassic (reddish K-feldspar + biotite \pm hematite), propylitic (chlorite + epidote + quartz + albite), sericite (quartz + sericite + sulfide \pm albite), adularia + sericite \pm rutile, argillic (illite) to late carbonate (calcite and Mn-calcite) alteration [26], besides silicification with associated fluorite. Adularia-sericite (Figure 4H), argillic, and carbonate alteration zones represent the $\mathrm{Au}-\mathrm{Ag}-(\mathrm{Cu}-\mathrm{Pb}-\mathrm{Zn})$ mineralization locus. A hematite-chlorite alteration was considered a proximal halo by $[35,104]$ or a distal alteration [104].

The shaft system of the Coringa deposit coincides with a $7 \mathrm{~km}$-long N- and NWtrending fault zone and encompasses five mineralized vein zones (Valdette, Galena, Mãe de Leite, Meio, Come Quieto; [103]). Ore zones include stockworks, sulfide-quartz veins controlled by brittle structures, commonly with comb, banded, crustiform, colloform, and brecciated textures, rare massive sulfide zones, and disseminated sulfides [26]. The main ore minerals are pyrite (Figure 4I), chalcopyrite, Fe-poor sphalerite, galena (Figure 4J), native silver, and gold, electrum (27 to $30 \% \mathrm{Ag}$; [35]), and minor digenite, bornite, argentite, tennantite, and secondary covellite and acanthite [26]. The gold content in veins decreases in-depth and outwards rhyolitic domes, similar to observed in typical epithermal veins [106].

Fluid inclusions trapped in quartz from mineralized veins reveals the presence of: (i) aqueous $\left(\mathrm{H}_{2} \mathrm{O}-\mathrm{NaCl}\right.$ ) fluid (salinity = up to $1.6 \mathrm{wt} . \% \mathrm{NaCl}$ eq.; $\mathrm{Th}=190$ to $252{ }^{\circ} \mathrm{C}$ ); aqueous-carbonic $\left(\mathrm{H}_{2} \mathrm{O}-\mathrm{CO}_{2}-\mathrm{NaCl}\right)$ fluid (salinity $=2.0$ to $7.4 \mathrm{wt} . \% \mathrm{NaCl}$ eq.; $\mathrm{Th}=315$ to 
$\left.355^{\circ} \mathrm{C}\right)$; and carbonic $\left(\mathrm{CO}_{2}\right.$-rich) fluids. Aqueous and aqueous-carbonic fluids have been interpreted as of meteoric and magmatic origin, respectively (Figure 6A) [35].
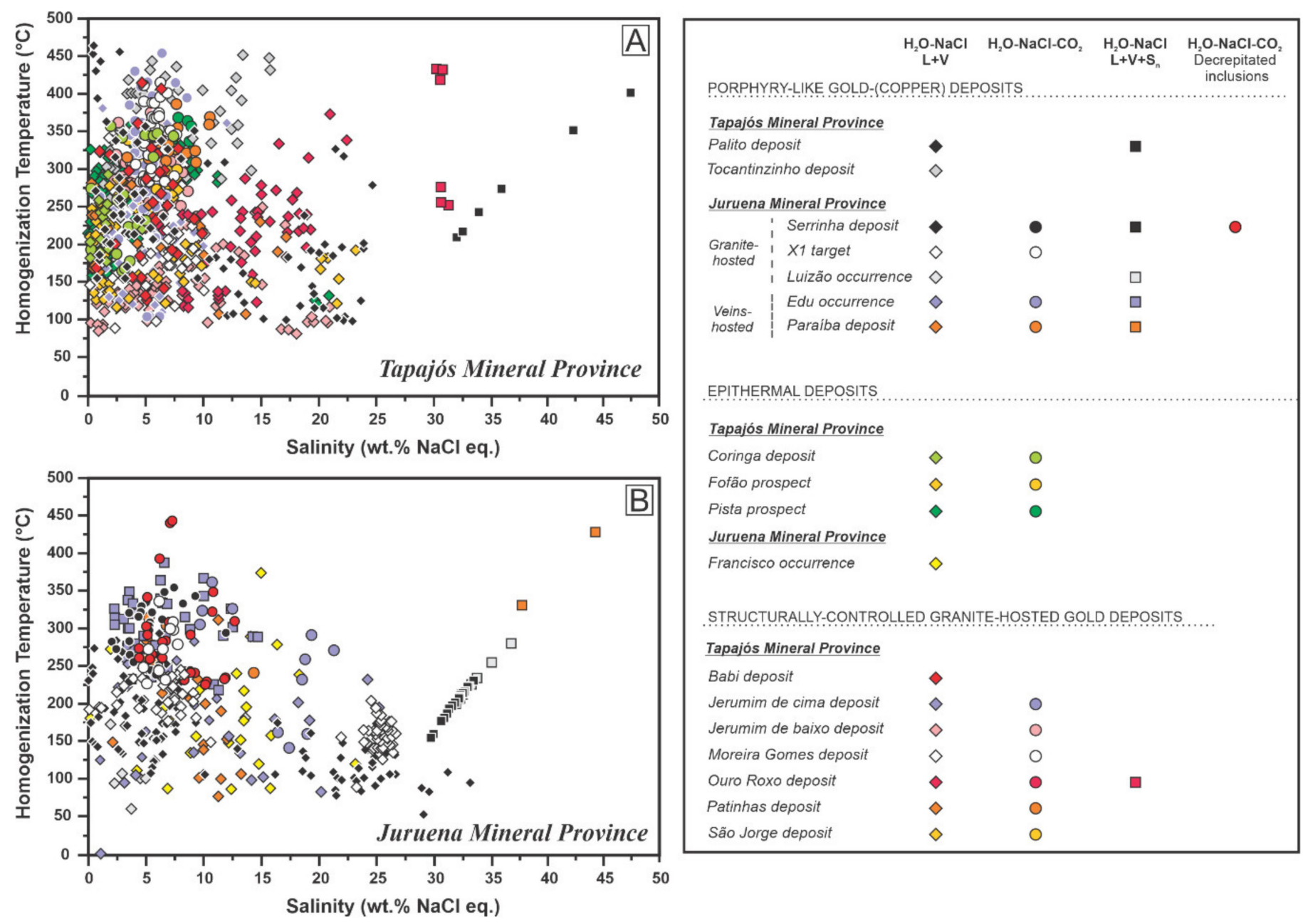

Coringa deposit

Fofão prospect

Pista prospect

Tapajós Mineral Province

Babi deposit

Jerumim de cima deposit

Jerumim de baixo deposit

Patinhas deposit

São Jorge deposit

O

Figure 6. Homogenization temperatures and salinities of aqueous $\left(\mathrm{H}_{2} \mathrm{O}-\mathrm{NaCl}\right)$ and aqueous-carbonic $\left(\mathrm{H}_{2} \mathrm{O}-\mathrm{NaCl}-\mathrm{CO}\right)$ fluid inclusions trapped in quartz from the gold-(polymetallic) deposits, prospects, and occurrences of the TMP (A) and JMP (B). Data source: TMP—[9,24,28,66,90,101,105,107-110]; JMP—[20,27,76,111-113].

The oxygen isotope composition of fluids in equilibrium with quartz, sericite, and calcite $\left(\delta^{18} \mathrm{O}_{\mathrm{H} 2 \mathrm{O}}=-1.8\right.$ to $9.8 \%$, at 400 to $\left.234{ }^{\circ} \mathrm{C}\right)$ points to mixing between magmatic and meteoric fluids [35] (Figure $5 \mathrm{~A})$. The $\delta \mathrm{D}_{\mathrm{H} 2 \mathrm{O}}$ values $(-92 \%$ ) estimated from the sericite could reflect vapor influence or extensive magma degassing. Also, boiling of a magmatichydrothermal fluid is indicated by platy calcite (sometimes replaced by silica) and adularia. The $\delta^{34} \mathrm{~S}$ values for galena and pyrite $(-10.9$ to $+1.8 \%$ o $)$ were considered as related to a reduced magmatic source [35]. However, these $\delta^{34} S$ values might result from sulfur isotope fractionation from a magmatic sulfur source at relatively high $f \mathrm{O}_{2}$ (hematitestable) conditions.

In the Coringa deposit, sericite-adularia alteration zones and open-space filling ore textures are typical of low-sulfidation epithermal deposits. However, the close relationship with the oxidized calc-alkaline rhyolite-andesite volcanic association, the intermediatesulfidation state sulfides (e.g., pyrite, chalcopyrite, Fe-poor sphalerite, galena, and tennantite), the presence of intermediate argillic alteration and Mn-bearing-carbonate, and the evidence of mixing between magmatic and meteoric water could reflect its formation in more oxidized and acidic conditions [106]. Thus, Coringa was interpreted as transitional from low- to intermediate-sulfidation $[26,107]$ or represent an intermediate-sulfidation 
epithermal deposit [35] with evolutionary changes in the oxidization state of the hydrothermal fluid.

$\mathrm{A} \mathrm{Pb}-\mathrm{Pb}$ model age of $1974 \mathrm{Ma}$ was obtained for gold-related pyrite crystals in sulfide-quartz veins hosted in dacite from the Mato Velho prospect, $20 \mathrm{~km}$ north of the Coringa deposit [114], suggesting a genetic relationship between gold mineralization and the volcanic host rocks [107]. This age may imply in a previous magmatic-hydrothermal system (ca. $1.97 \mathrm{Ga}$ ) at the TMP concerning the ca. 1.87 Ga Botica Velha (V3) highsulfidation deposit.

\section{Low-Sulfidation Epithermal Au Deposits}

The Chapéu de Sol Au-Cu-Mo deposit is hosted by a lower volcanic unit $(1990 \pm 12 \mathrm{Ma}$, SHRIMP IIe U-Pb zircon; basaltic andesite, andesite, rhyolite, ignimbrite, rhyolite porphyry, and associated monzogranite) and an upper volcanic-volcaniclastic unit (1888 \pm 6 Ma to $1873 \pm 4.9 \mathrm{Ma}$; rhyolite, ignimbrites, crystal-, lapilli- and ash-tuffs, coignimbrite breccias, and epiclastic and lacustrine sedimentary rocks; [22]). The latter unit was formed in a volcanic caldera structure and post-caldera ring volcanoes. Rhyolite domes are also related to resurgent magmatism [18]. Both lower and upper units include subalkaline, metaluminous to peraluminous, high-K calc-alkaline rocks.

The volcanic-volcaniclastic units were intercepted by hornblende-bearing rhyodacite porphyry $(1880 \pm 7.8 \mathrm{Ma}$ to $1861 \pm 8.9 \mathrm{Ma})$ in the post-caldera stage. The basement of the volcanic-volcaniclastic units is represented by $2003 \pm 8.9$ Ma biotite-hornblende monzogranite [22].

The monzogranite and rhyodacite porphyry underwent an early stage of hydrothermal sodic (albite) alteration, followed by potassic (K-feldspar + biotite + quartz + magnetite), sericite, and propylitic alteration. In the volcanic-volcaniclastic units, potassic alteration evolves to intense, pervasive chlorite + (epidote + carbonate), sericite (quartz + sericite + pyrite + chalcopyrite), adularia + sericite, propylitic, and argillic (kaolinite + illite + allophane + chalcedony + hematite) alteration $[22,115]$. The adularia-sericite alteration was especially well-developed in volcaniclastic rocks. The propylitic alteration assemblage include chlorite + epidote + albite + (platy calcite + fluorite + adularia + barite + rutile + pyrite + chalcopyrite) and was formed at 410 to $350^{\circ} \mathrm{C}[22,115]$.

The gold-polymetallic mineralization is spatially associated with sericite-(adularia) and propylitic alteration with adularia zones. Ore minerals occur disseminated in altered subvolcanic, volcanic, and volcaniclastic rocks and in fracture-controlled stockwork veinlets. Pyrite, chalcopyrite, bornite, sphalerite, galena, molybdenite, native silver, gold, and minor bismuthinite, wolframite argentite, hessite, petzite, anillite, hedleyite compose the ore mineral association. In the rhyodacite porphyry, irregular A, B, and D veins are also filled by quartz-chalcopyrite, pyrite-chalcopyrite-bornite, and pyrite-quartz [66].

The presence of platy calcite and adularia evidences the boiling process, typical of lowsulfidation epithermal gold deposits. However, the polymetallic mineralization resulted from the overlap of a porphyry $\mathrm{Cu}-\mathrm{Au}$-Mo type mineralization over low-sulfidation alteration zones, both linked to porphyry dikes coeval to the ca. 1.87 Ga Botica Velha (V3) high-sulfidation deposit [22,115].

\subsubsection{Porphyry-Like $\mathrm{Au}-(\mathrm{Cu})$ Deposits}

The shallow-emplaced granite-hosted gold and gold-(copper) deposits are similar to porphyry deposits in genesis and, in some cases, in style, in the TMP. The main of them are the Tocantinzinho and Palito (Table S1, Supplementary Materials) deposits, described below due to their distinctive features.

\section{Tocantinzinho Porphyry-Style Gold Deposit}

The Tocantinzinho is the largest gold deposit of the TMP (Figure 3C), with indicated resources of $49 \mathrm{Mt} @ 1.35 \mathrm{~g} / \mathrm{t}$ Au (average) or up to $65.8 \mathrm{t}$ of gold [116]. The deposit is located along a major regional NW-trending brittle fault zone, which controlled the 
emplacement of multi-phase intrusions (Figure 3C). Post-mineralization NE-SW-trending and E-W steeply-dipping faults intercept the mineralized granites [89].

The main host rocks are isotropic syenogranite (1996 $\pm 2 \mathrm{Ma}$; U-Pb zircon) and monzogranite (1989 $\pm 1 \mathrm{Ma}$ ) [31]. Nearly coeval intrusions comprise alkali-feldspar granite, monzonite, syenite, and andesite dikes (1998 $\pm 8 \mathrm{Ma})$, porphyritic rhyolite, aplite, pegmatite, and mafic rocks $[24,31,116]$. Basement rocks include ca. 2007 Ma granodiorite. The multi-phase intrusions represent oxidized, I-type magmas high-K calc-alkaline and metaluminous to peraluminous affinity $[24,30,31]$.

Unidirectional solidification textures (UST), interconnected miarolitic texture (IMT), rapid grain size variations from pegmatite to aplite, and vein dykes, represent notable magmatic-hydrothermal transition textures at Tocantinzinho [116] and indicate the shallow granite emplacement.

All rocks in the Tocantinzinho area are hydrothermally altered, brecciated, and fractured [30]. The hydrothermal alteration resulted in two groups of altered granite rocks. The "Smoky"-type occurs in the inner deposit parts, is pale pink-grey, coarse-grained, chlorite-sericite-rich, and has a blebby texture, similar to IMT. The "Salame"-type is a red-pinkish, coarse-grained, equigranular, microcline-quartz-rich rock, with IMT texture and transitions into aplite-pegmatite zones [24,25,89,116,117].

A continuous transition from "Salame"- to "Smoky"-types is due to evolution from intense potassic (microcline + milky quartz \pm albite \pm hematite) alteration and silicification to chloritic (chlorite + rutile + pyrite + chalcopyrite), sericitic (sericite + pyrite + quartz), and carbonate alteration [24,25].

Disseminated- and stockwork-style gold mineralization is mostly associated with sericitic alteration zones. Gold particles, chalcopyrite, sphalerite, galena, altaite, and minor molybdenite petzite, bismuthinite and native silver argentite, Cu-bismuthinite, hedleyite, hessite, and native bismuth occur in the irregular veinlet networks, associated with magnetite, hematite, chlorite-quartz-calcite [24,25]. The Au/Ag ratios in gold particles vary from 2.5 to 11.2 [30].

Muscovite and sericite ${ }^{40} \mathrm{Ar}-{ }^{39} \mathrm{Ar}$ plateau ages (1854 $\pm 6 \mathrm{Ma}$ and $\left.1865 \pm 5 \mathrm{Ma}\right)$ might reflect isotopic resetting [30]. The $\delta^{13} C_{\text {calcite }}$ values ( -3.45 to $-2.29 \%$ ) imply a deep-seated carbon source, consistent with a magmatic fluid contribution, as suggested by the calculated $\delta^{18} \mathrm{O}_{\mathrm{H} 2 \mathrm{O}}$ values $\left(+0.39\right.$ to $+8.52 \%$, at $\left.300{ }^{\circ} \mathrm{C}\right)$ in equilibrium with calcite [117].

Fluid inclusions trapped in hydrothermal quartz related to potassic and sericite alteration reveal the presence of aqueous $\left(\mathrm{H}_{2} \mathrm{O}-\mathrm{NaCl}\right)$ fluids with variable salinity $(0.2$ to 15.9 wt. $\% \mathrm{NaCl}$ eq.) and homogenization temperatures (100 to $433^{\circ} \mathrm{C}$; Figure $\left.6 \mathrm{~A}\right)$. The coexistence in an equilibrium of fluid inclusions that homogenize to vapor or liquid phase, at similar temperatures, was interpreted by [24] as evidence of boiling during the magmatic fluid ascent, followed by mixing between magmatic and meteoric fluids.

The Tocanzinho deposit has been considered a magmatic-hydrothermal deposit, classified as a (reduced) intrusion-related gold deposit [25], which are associated with ilmenite-bearing granitoids. However, similarities with a porphyry-style gold deposit have been recognized due to its genetic relationship with a shallow-emplaced oxidized calc-alkaline monzogranite $[24,30]$.

\section{Palito Gold-(Copper) Deposit}

The Palito gold-(copper) deposit (Figure 3B) represented the first operational polymetallic underground mine in the TMP, producing $3.12 \mathrm{t}$ of gold from 2003 to 2008. Proven and probable reserves at Palito were estimated at 717,000 $\mathrm{t} @ 11.74 \mathrm{~g} / \mathrm{t}$ of gold [104].

The Palito deposit is hosted by a fine- to medium-grained porphyritic granite (Palito Granite; $1883 \pm 11 \mathrm{Ma}$; $\mathrm{Pb}-\mathrm{Pb}$ zircon; [118]), which is intrusive in the Rio Novo Granite (1881 $\pm 4 \mathrm{Ma}$; Pb-Pb zircon; [119]) and Fofoquinha Granodiorite (1946 $\pm 57 \mathrm{Ma} ; \mathrm{Pb}-\mathrm{Pb}$ zircon; [119]) (Figure 3B). These rocks are crosscut by later magnetite granite stocks, rhyolite porphyry, diabase, and mafic dikes and overlain by rhyolite, ignimbrite, and tuffs. The granitoid rocks are oxidized and have high-K calc-alkaline to alkalic-calcic affinity [66]. 
Despite the mineralization that invades the Palito Granite country rocks, the intensity of hydrothermal alteration, vein frequency and thickness, and ore grade decrease outwards the Palito Granite [100] (Figure 3B). The granite has a distinctive reddish color related to potassic alteration (Figure $4 \mathrm{~K}-\mathrm{M}$ ) with microcline and minor hydrothermal biotite. Infiltration textures suggest open-space or miarolitic cavity filling processes during the potassic alteration. This alteration evolves outwards to fracture-controlled and pervasive propylitic alteration with chlorite, epidote, albite, carbonate (platy calcite), titanite, fluorite, and minor prehnite. Upwards, a well-developed sericitic alteration encompasses sericite, quartz and sulfides. Minor fracture-controlled argillic/advanced argillic alteration (pyrophyllite + sericite + kaolinite) occurs.

The gold-(copper) mineralization zone is controlled by vertical to sub-vertical, NW-SE and E-W-trending brittle extensional fault systems and contained in up to one-meter-thick sulfide-quartz and semi-massive sulfide veins (Figure $4 \mathrm{~K}, \mathrm{M}$ ), stockworks, hydrothermal breccias (Figure $4 \mathrm{~L}$ ), and finely disseminated sulfides within the Palito Granite and at the contact with the Rio Novo Granite [100,104] (Figure 3B). Potassic, sericite, and propylitic alteration selvages are associated with the mineralized sulfide-(quartz) veins.

The main ore minerals are chalcopyrite, pyrite, and gold, and minor pyrrhotite, digenite, chalcocite, gold-silver alloys (25-30\% of Ag), galena, sphalerite, covellite, barite, bismuthinite, hedleyte, matildite, wittichenite, tetradymite, and scheelite. Gold particles occur as inclusions in chalcopyrite. The mineralized veins are intercepted by late NW-SEand E-W-trending faults and commonly are sheared or brecciated. Barren quartz-pyrite(carbonate-fluorite) and massive pyrite veins with incipient chlorite selvages are controlled by post-mineralization brittle faults [100]. A Pb-Pb pyrite age of $1797 \pm 17 \mathrm{Ma}$ [118] was obtained in post-ore barren veins defined by [100].

Fluid inclusions data reveal at least three fluid types related to the gold mineralization of the Palito deposit (Figure 6A): (1) an early aqueous-carbonic $\left(\mathrm{H}_{2} \mathrm{O}-\mathrm{CO}_{2}-\mathrm{NaCl}\right)$ fluid with low salinity (1.1-1.7 wt.\% $\mathrm{NaCl}$ eq.); (2) an aqueous $\left(\mathrm{H}_{2} \mathrm{O}-\mathrm{NaCl}-\mathrm{FeCl}_{2}\right)$ fluid with high salinity (45-50 wt.\% $\mathrm{NaCl}$ eq.); and (3) aqueous $\left(\mathrm{H}_{2} \mathrm{O}-\mathrm{NaCl}\right)$ with low salinity (<2.0 wt.\% $\mathrm{NaCl}$ eq.). An early magmatic fluid exsolution stage resulted in a vapor-rich aqueous-carbonic fluid of low salinity and high homogenization temperature $\left(429-462{ }^{\circ} \mathrm{C}\right)$, which evolved through a continuous boiling process and mixed with meteoric fluids, resulting in aqueous fluids with variable salinity and homogenization temperature (100 up to $>400{ }^{\circ} \mathrm{C}$ ) [28].

Calculated stable oxygen and hydrogen isotope composition of hydrothermal fluids in equilibrium with potassic feldspar $\left(\delta^{18} \mathrm{O}_{\mathrm{H} 2 \mathrm{O}}=+7.2\right.$ to $+6.3 \%$ o $)$, at $450{ }^{\circ} \mathrm{C}$, and quartz, sericite, and chlorite $\left(\delta^{18} \mathrm{O}_{\mathrm{H} 2 \mathrm{O}}=+6.3\right.$ to $-2.6 \% ; \delta \mathrm{D}_{\mathrm{H} 2 \mathrm{O}}=-55.4$ to $+0.2 \%$ o $)$, at $350{ }^{\circ} \mathrm{C}$, suggest earlier stages of potassic alteration related to magmatic fluids, followed by the influx of meteoric fluids and seawater (Figure $5 \mathrm{~A}$ ). The $\delta^{34} \mathrm{~S}$ values (1.2 to $3.6 \%$ ) for pyrite, chalcopyrite, and pyrite are consistent with a magmatic sulfur source [100].

The geochemical signature and evolution of the magmatic associations, types and styles of hydrothermal alteration, metal associations, and the physicochemical conditions of the mineralizing fluids of the Palito deposit were considered compatible with those of magmatic-hydrothermal porphyry-type gold systems [28,65,100].

\subsubsection{Structurally-Controlled Granite-Hosted Gold Deposits}

Other structurally-controlled gold deposits are hosted by deep- to shallow-emplaced granites in the TMP (e.g., Ouro Roxo, São Jorge (Figure 3D), Central, Moreira Gomes, Jerimum de Baixo, Jerimum de Cima, Babi, Patinhas, Guarim). Several of them are part of the Cuiú-Cuiú gold camp (Table S1, Supplementary Materials), where, until the 90's, artisanal explorers produced at least $62 \mathrm{t}$ of gold. Measured resources of the main deposits (Central and Moreira Gomes) reveal 48.7 Mt @ $1.35 \mathrm{~g} / \mathrm{t} \mathrm{Au}$, with indicated resources of up to $2.4 \mathrm{Mt} @ 0.9 \mathrm{~g} / \mathrm{t} \mathrm{Au} \mathrm{[120]}$

These deposits are hosted by I-type, calc-alkaline granitoids, including ca. 2.02 Ga biotite-hornblende tonalite, granodiorite, monzogranite (e.g., Cuiú-Cuiú camp), ca. 1.98 Ga 
monzodiorite and monzogranite (e.g., São Jorge; Figure 3D), and ca. 1.89 to 1.91 Ga diorite, hornblende-biotite monzogranite, granodiorite, tonalite (e.g., Cuiú-Cuiú camp, São Jorge, and Ouro Roxo [3,108,121-123].

The granitoids underwent pervasive and fissure-controlled hydrothermal chloritic, sericitic, carbonate, propylitic alteration, and silicification $[10,101,108,109,121,124,125]$. Replacement of igneous feldspars by hydrothermal K-feldspar, as a result of potassic alteration, was recognized in the Guarim [10] and São Jorge [124] deposits. In other deposits, strong red color in cloudy K-feldspar, similar to that typical of the potassic alteration fronts at Palito, Tocantinzinho, and Batalha [18], has been considered an original granite feature [123] or due to an iron oxide-chlorite alteration [124].

The gold mineralization is mainly related to stockworks, sheeted quartz-sulfide veins, veinlet networks, cataclastic breccias, and disseminated ore controlled, at deposit scale, by NE-SW-, NW-SE-, WNW-SSE-, WSW-ENE-, and N-S-trending faults within a large-scale, regional NW-SE-striking lineament (Table S1, Supplementary Materials). At the Ouro Roxo deposit, granite mylonitization and brecciation and shearing of mineralized veins were reported [126].

The gold particles occur in low- $(1-2 \mathrm{~g} / \mathrm{t} \mathrm{Au})$ and high-grade $(>10 \mathrm{~g} / \mathrm{t} \mathrm{Au})$ quartz veins related to a higher sulfide content and intensity of sericitic alteration. Gold is associated with pyrite, pyrrhotite, chalcopyrite, galena, sphalerite, magnetite, and minor molybdenite, hessite, bismuthinite, native bismuth and silver [9,101,108,121,122,124,125].

Similar fluid types have been identified in quartz from gold-mineralized veins (Figure 6A), including (i) an aqueous $\left(\mathrm{H}_{2} \mathrm{O}-\mathrm{NaCl}\right)$ fluid with variable salinity $(0.0-30 \mathrm{wt} . \% \mathrm{NaCl}$ eq.) and homogenization temperature $\left(104\right.$ to $\left.410{ }^{\circ} \mathrm{C}\right)$; (ii) aqueous-carbonic $\left(\mathrm{H}_{2} \mathrm{O}-\mathrm{CO}_{2}-\mathrm{NaCl}\right)$ fluid with salinities between 1.6 to $19 \mathrm{wt} . \% \mathrm{NaCl}$ eq. and homogenization temperature of 114 to $448{ }^{\circ} \mathrm{C}$; and (iii) carbonic $\left(\mathrm{CO}_{2}\right.$-rich) fluids $[9,10,90,101,108-110,121,124]$. These data were interpreted as suggestive of evolution from a metamorphic aqueous-carbonic fluid channeled within the brittle-ductile faults, which underwent immiscibility and pressure fluctuations (e.g., Guarim; [9,10]) possibly with a contribution of magmatic brines [90]. Alternatively, the boiling of a magmatic aqueous-carbonic fluid would have been responsible for phase separation (i.e., $\mathrm{CO}_{2}$-rich and aqueous fluids), followed by mixing with diluted, colder meteoric fluids [110].

Stable isotope composition of sulfides $\left(\delta^{34} \mathrm{~S}=+0.29\right.$ to $\left.+3.95 \%\right)$ and fluids $\left(\delta^{18} \mathrm{O}_{\mathrm{H} 2 \mathrm{O}}=\right.$ $+10.1 \%$ to $+0.5 \%$ and $\delta \mathrm{D}=-49$ to $-0.8 \%$, at $305-205^{\circ} \mathrm{C}$ ) are also consistent with magmatic fluid and sulfur sources, and mixing with externally-derived fluids $[8,101,110]$.

These granite-hosted deposits and targets were considered similar to orogenic gold deposits $[9,109]$ or associated with an intrusion-related gold system $[90,101,108,110]$.

\subsubsection{Hydrothermally-Modified Sediment-Hosted Gold Deposits}

The Castelo de Sonhos gold deposit has 40.1Mt @ $1.2 \mathrm{~g} / \mathrm{t}$ Au of indicated resources, or $1.5 \mathrm{Moz}$ of gold, whereas inferred resources point to $22.2 \mathrm{Mt} @ 1.0 \mathrm{~g} / \mathrm{t} \mathrm{Au}$ or $0.7 \mathrm{Moz}$ of gold [127]. The gold mineralization is hosted in the ca. 2.01-2.05 Ga Castelo de Sonhos Formation [127], which forms a 15 vs. 12 km, 1100 m-thick plateau. It comprises conglomerates, conglomeratic sandstones, and magnetite-rich sandstones and was interpreted as a relic of a coastal sedimentary basin $[127,128]$. Locally, mineralized conglomerate layers are sheared, folded and intercepted by porphyritic dacite dikes (2011 \pm 6 Ma; LA-ICP-MS $\mathrm{U}-\mathrm{Pb}$ zircon; [129]) and biotite granodiorite (1976 $\pm 7 \mathrm{Ma}$; SHRIMP U-Pb zircon; [129]).

The conglomerate layer is the primary mineralization host [127], but geological crosssections evidence the continuity of orebodies into sandstones [130]. The hydrothermal alteration, mainly incipient to pervasive silicification, hematite sericite-(muscovite + fuchsite), tourmaline, epidote, and argillic alteration, envelops the orebodies [130]. Gold, usually associated with muscovite or magnetite, occurs within detrital quartz grains and as intergranular particles in the conglomerate and sandstone matrix. Gold grains have low Ag contents ( $<1$ to $4.7 \%)$ and lack other significant metals, suggesting a single source. Minor gold mineralization is fracture-controlled, related to secondary iron oxides. Platy gold 
particles have lower Ag contents $(<1 \%)$, interpreted as a result of epigenetic remobilization of the matrix gold [131].

The gold deposits on the Castelo de Sonhos plateau are classified as modified paleoplacers [127]. The morphology of the gold particles is only slightly modified and reshaped, which suggests detrital provenance and a relatively proximal distance of transport. According to [131], hydrothermal fluids exsolved from the subjacent biotite granodiorite triggered gold remobilization to fractures. Also, the low-temperature hydrothermal alteration, mainly argillic to sericitic, and the orebody geometry associated with dacite porphyry dikes may suggest an epithermal style overprint.

\subsection{Gold Deposits in the Juruena Mineral Province}

Gold mineralization in the JMP corresponds to Cenozoic placers, eluvial deposits, and hydrothermal occurrences, concentrated over the $150 \mathrm{~km}$ WNW-ESE-striking Peru-Trairão belt, but known gold occurrences extend westwards (Figure 2). Placers and eluvial deposits are associated with primary gold ores hosted in faults and granite intrusions distributed in zones roughly parallel to the outcrops of the volcanic units, suggesting that the weathering and erosional front advance resulted in the gold concentration from the rhyolitic to dacitic volcanic rocks and exposed veins and stockworks in faults and granites. Some of these shallow-emplaced granite stocks and dikes could represent feeder channels for the volcanic and volcaniclastic cover.

The primary gold mineralization has been studied by several authors since 2000's years $[11,19,20,27,29,62,76,111,112,132-136]$. Based on mineralization style and mineral paragenesis of the ore bodies, similarly as proposed by [1], gold occurrences were grouped as: (i) intrusion-hosted disseminated, stockworks and veins in shallow-emplaced granites; (ii) veins hosted in faults crosscutting granitoids; and (iii) epithermal polymetallic veins in porphyries, volcanic and volcaniclastic rocks [29,38] (Table S2, Supplementary Materials). Overall, aplite and mafic to intermediate volcanic dikes, affected by hydrothermal alteration with disseminated sulfides, crosscut the host rocks of most known gold occurrences [29].

\subsubsection{Shallow-Emplaced Granite-Hosted Disseminated, Stockwork and Vein Gold Ores}

The Luizão, Serrinha, Juruena, X1, Pé Quente, and Papagaio are the more important intrusion-hosted disseminated, stockwork and vein gold deposits or occurrences (Table S2, Supplementary Materials). Available measured and indicated resources for the $\mathrm{X} 1$ prospect are $8.0 \mathrm{Mt}$ of gold, grading $1.35 \mathrm{~g} / \mathrm{t} \mathrm{Au}$ and $4.6 \mathrm{~g} / \mathrm{t} \mathrm{Ag}$ (11.2 t Au equivalent) $[11,20,23,62,111,133]$.

The Luizão is hosted by the ca. 1.98-1.97 Ga Novo Mundo syeno- and monzogranite [11], whereas the Pé Quente occurs into the ca. 1.97 Ga Pé Quente monzonite and ca. $1.9 \mathrm{Ga}$ Guarantã biotite-bearing tonalite and granodiorite [23], which also hosts the X1 target (Figure 7A) [111]. The Pé Quente and X1 deposits are also hosted by ca. 1.97 and $1.78 \mathrm{Ga}$ granodioritic and tonalitic porphyries [23,111]. The ca. $1.87 \mathrm{Ga}$ Matupá biotite granite is the main host of the Serrinha deposit [20]. The Juruena deposit is centered in ca. 1.81-1.79 Ga Paranaíta biotite monzogranite, porphyritic biotite monzogranite and microgranite [133]. The younger host units were identified in the Papagaio deposit and comprise calc-alkaline granite, granodiorite, dacite, rhyolite and volcaniclastic rocks. These rocks, likely generated in a volcanic caldera complex, are attributed to the ca. $1.78 \mathrm{Ga}$ volcanic Colíder Group [62].

Collectively, the 1.97-1.78 Ga set of host rocks, ranging from tonalite to syenogranite (Figure 7A), represent I-type, magnetite-bearing, sub-alkaline to calc-alkaline, metaluminous to slightly peraluminous magmatism [29]. These granites exhibit $\varepsilon \mathrm{Nd}_{(\mathrm{t})}$ values from -5.13 to -2.08 and $\mathrm{Sm}-\mathrm{Nd} \mathrm{T}_{\mathrm{DM}}$ model ages between 2.51 to $2.28 \mathrm{Ga}$, suggesting Archean to Paleoproterozoic mantle-derived magmas with minor continental assimilation $[11,76,78,81]$.

The hydrothermal alteration spectrum is wide and diverse, although the potassic (Kfeldspar \pm biotite), sericitic (sericite \pm fine-grained muscovite/phengite + quartz + pyrite) 
chloritic and propylitic (chlorite + epidote + clinozoisite \pm calcite \pm apatite \pm rutile \pm pyrite \pm chalcopyrite) alteration types are the most common (Figure 7B). They occur as pervasive, vein-type, stockworks and breccias styles. An incipient albite alteration is usually observed replacing the igneous feldspar, followed by an intense K-feldspar alteration and more restricted biotite-rich alteration (e.g., Pé Quente occurrence). Strong potassic alteration over monzogranite to tonalite commonly result in reddish rocks of alkali-feldspar to quartz syenite composition. The propylitic and chloritic alteration corresponds to the outermost or shallower alteration halo, and extensive zones of chlorite-sericite alteration are prevalent. Carbonate-rich alteration and silicification, associated with quartz infill, represent less intense alteration zones $[11,20,23,62]$.

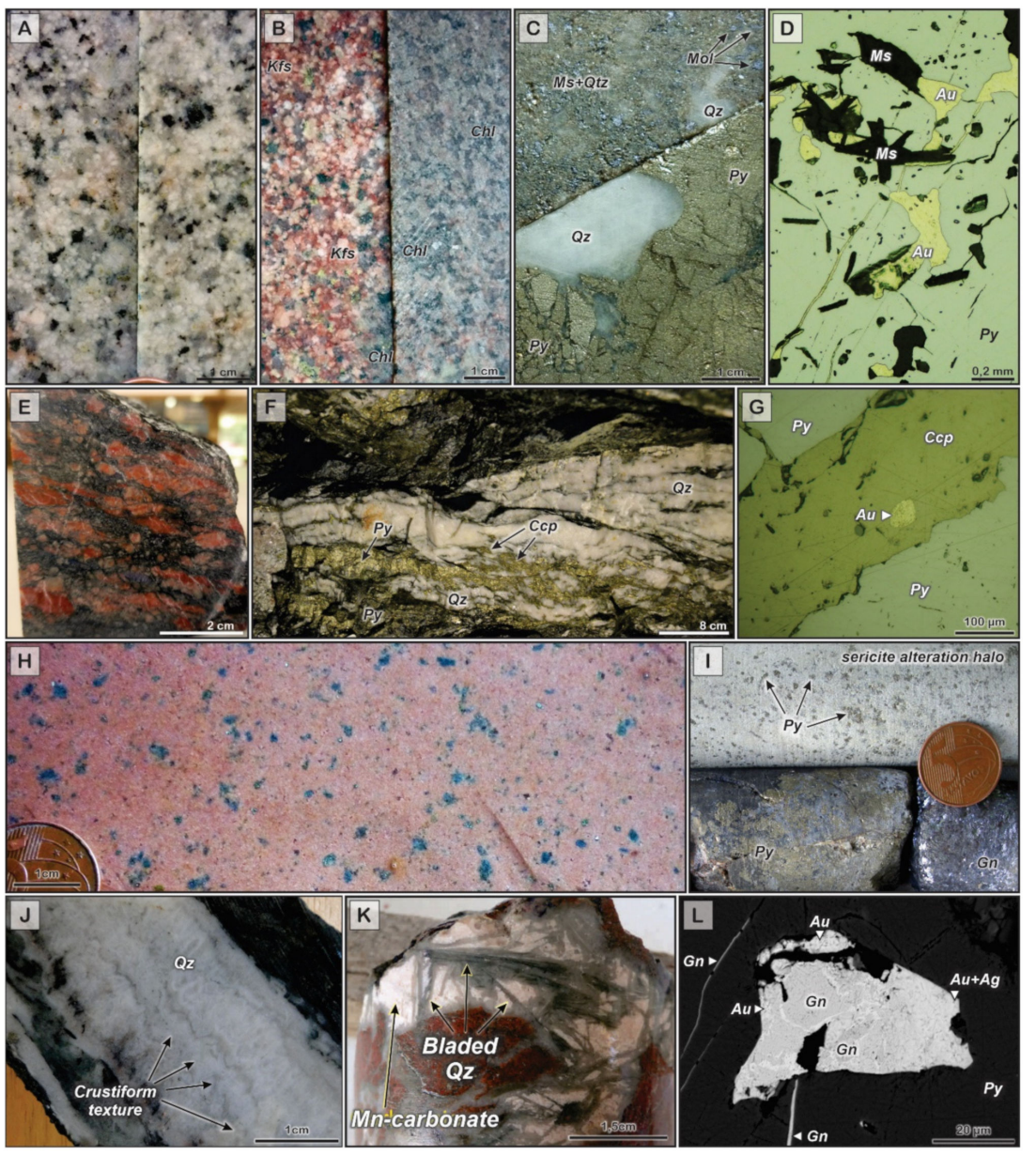

Figure 7. Major features concerning the gold deposits and occurrences from the Juruena Mineral Province. (A) Host rock of tonalitic-granodioritic composition from the X1 and Pé Quente deposits; (B) The inner area related to the granite-hosted systems are represented by pervasive potassic (K-feldspar-quartz-hematite) alteration, whereas the outer and more regional alteration halo is composed of propylitic chloritic alteration (chlorite-epidote-calcite); (C) Ore-shoots are mainly related to muscovite-quartz-pyrite alteration, with minor amounts of chalcopyrite and molybdenite; (D) Gold as inclusions in pyrite or filling its fractures; (E) Orthogneisses with pervasive potassic (K-feldspar) alteration, often observed in the vein-hosted deposits; (F) Quartz \pm carbonate veins with pyrite- and chalcopyrite-bearing gold; $(G)$ Gold inclusion in chalcopyrite in the Paraíba veinhosted gold deposit; (H) Porphyries of granodioritic to tonalitic composition, which host several gold deposits and occurrences; (I) Pyrite-galena veins with sericite alteration halo from the Francisco epithermal gold deposit; (J) Crustiform texture in epithermal vein; (K) Bladed quartz and Mncarbonate-quartz veins from the Luiz epithermal occurrence; (L) galena-gold-silver inclusion in pyrite from the Francisco epithermal occurrence. Mineral Abbreviation after [92]. 
Late veinlets are relatively common (e.g., quartz, quartz-carbonate, chlorite, chloriteepidote-quartz, chlorite-sulfide). Narrow K-feldspar \pm quartz or chlorite-quartz-platy calcite veinlets are also recognized, as well as ABDM veins, as proposed by [137]. Faults also controlled the mafic dike emplacement and hydrothermal fluid flow, which resulted in a second sub-euhedral pyrite and chalcopyrite generation.

The gold ore is mainly associated with sericitic alteration (quartz + sericite and finegrained muscovite + pyrite) (Figure 7C) and minor with sericite-chlorite alteration. It is mainly composed of pyrite, with variable chalcopyrite and hematite amounts and subordinate barite, galena, sphalerite, monazite, thorite, molybdenite, pyrrhotite, cubanite, $\mathrm{Bi}-\mathrm{Te}-$ bearing phases, and $\mathrm{Au}-\mathrm{Ag}$ tellurides inclusions. Gold $(\mathrm{Au} / \mathrm{Ag}=2.2-25)$ occurs as inclusions in pyrite or as $\mathrm{Au}-\mathrm{Ag}$ alloys at its edges or fractures (Figure 7D). At the $\mathrm{X} 1$ prospect, gold grades vary from 0.5 to $10 \mathrm{~g} / \mathrm{t} \mathrm{Au}$. The highest gold values occur in disseminated and massive sulfide zones and the lowest in the stockwork zones $(<0.2 \mathrm{~g} / \mathrm{t})$. Particularly in high-grade gold zones, copper may reach values between 0.1 and $0.5 \mathrm{wt} . \%$ and Mo between $200 \mathrm{ppm}$ to $0.1 \mathrm{wt} . \%$ [111]. Moreover, whole-rock geochemistry of the ore shoots has demonstrated positive correlations of $\mathrm{Au}, \mathrm{Bi}$ and Te at Luizão and X1 [29,111].

Fluid inclusion assemblages reveal the presence of: (1) aqueous $\left(\mathrm{NaCl}-\mathrm{H}_{2} \mathrm{O}\right)$ fluids with variable homogenization temperatures $\left(126.5^{\circ} \mathrm{C}\right.$ to $\left.268.4^{\circ} \mathrm{C}\right)$ and salinities (2.1 to 26.1 wt.\% $\mathrm{NaCl}$ eq.); (2) aqueous-carbonic $\left(\mathrm{H}_{2} \mathrm{O}-\mathrm{CO}_{2}\right)$ fluid of high-temperature $\left(251.6^{\circ} \mathrm{C}\right.$ to $334.6{ }^{\circ} \mathrm{C}$ ) and relatively low-salinity (6.1-8.9 wt.\% $\mathrm{NaCl}$ eq.), and (3) high-salinity (33.6-37 wt.\% $\mathrm{NaCl}$ eq.) aqueous $\left(\mathrm{NaCl}-\mathrm{H}_{2} \mathrm{O}\right)$ fluids, represented by halite-bearing fluid inclusions of restricted occurrence (Figure $6 \mathrm{~B})$. The $\delta \mathrm{D}_{\text {silicate }}(-15 \%$ to $-34 \%), \delta^{18} \mathrm{O}_{\mathrm{H} 2 \mathrm{O}}$ $\left(+2.9 \%\right.$ to $+8.2 \%$, at $\left.209-458{ }^{\circ} \mathrm{C}\right)$, and $\delta^{34} \mathrm{~S}_{\text {pyrite }}(-5.6 \%$ to $+3.5 \%$ o $)$ suggest a predominately magmatic-hydrothermal source (Figure 5B) [20,76].

EMPA analyses indicate homogeneity on chlorite, muscovite and sericite compositions. The $\mathrm{Fe} /(\mathrm{Fe}+\mathrm{Mg})$ ratios and $\mathrm{Al}^{\mathrm{IV}}$ (a.p.f.u.) for chlorite vary from 0.27-0.7 and 1.1-1.3, reflecting a brunsvigite-type chlorite. The $\mathrm{SiO}_{2}$ and $\mathrm{Al}_{2} \mathrm{O}_{3}$ contents for muscovite (44.4$56.3 \mathrm{wt.} \%$ and $22.1-37.3 \mathrm{wt} . \%$ ) and sericite (45.4-61.3 wt.\% and $18.8-34.8 \mathrm{wt} . \%)$ show a muscovite-phengite trend towards the phengite endmember. Moreover, the low $\mathrm{Ti}$ contents (up to $0.56 \%$ ) for white mica indicate their hydrothermal origin [138-140]. The chlorite geothermometer indicates temperatures from $225^{\circ}$ to $384^{\circ} \mathrm{C}$ for the propylitic and chloritic alteration stages. Pressures between 0.49 and $1.5 \mathrm{kbar}$ (depth of 1.78-5.44 km) were obtained using the muscovite geobarometer [140].

The LA-ICP-MS trace element analyses of pyrite reveal a wide range in $\mathrm{Bi}(0.02-0.34 \mathrm{ppm})$, $\mathrm{Cu}$ (2.2-261 ppm), Ni (2.1-310 ppm), Co (2.5-2850 ppm), and As (34-3635 ppm) contents. The $\mathrm{Au}$ and $\mathrm{Ag}$ values, however, were below the detection limit $(<0.05 \mathrm{ppm})$ [113]. In addition, EMPA trace elements analysis of pyrite reported elevated Ag (up to $400 \mathrm{ppm}$ ) and variable $\mathrm{Au}$ contents (200-2000 ppm). These granitic-centered systems exhibit a weighted average of pyrite and molybdenite Re-Os model ages of $1805 \pm 7 \mathrm{Ma}$ [133] and $1786 \pm 3.2 \mathrm{Ma}$ [134].

\subsubsection{Structurally-Controlled Veins}

The Paraíba, Edu, Peteca, Basílio, Serrinha do Guarantã, and Aguinaldo represent the major known fault-controlled gold veins (Table S2, Supplementary Materials). At the Paraíba deposit, drill cores along the vein strike have intercepted up to $4 \mathrm{~m}$ intervals with grades varying from $0.2 \mathrm{~g} / \mathrm{t}$ of $\mathrm{Au}$ up to $29 \mathrm{~g} / \mathrm{t}$ of Au. The estimated ore reserves are in the order of $350,000 \mathrm{t} @ 15,35 \mathrm{~g} / \mathrm{t}$ of Au, equivalent to $5.37 \mathrm{t}$ of $\mathrm{Au}[2,11,27,63,112,132]$.

These fault-controlled veins crosscut a wide diversity of rocks, such as ca. $2.7 \mathrm{Ga}$ biotite gneiss ( $\mathrm{T}_{\mathrm{DM}}$ ages from 2.72 to $2.62 \mathrm{Ga} ; \varepsilon \mathrm{Nd}_{(\mathrm{t})}=+2.2$ to +3.6 ) (Figure 7E); ca. 2.05 to $1.98 \mathrm{Ga}$ granitic to tonalitic orthogneiss; ca. $2.01 \mathrm{Ga}$ dacite; ca. $2.01 \mathrm{Ga}$ tonalite; ca. 2.02-1.96 Ga granodiorite to syenogranite $\left(\mathrm{T}_{\mathrm{DM}}\right.$ ages from 2.49 to $2.32 \mathrm{Ga} ; \varepsilon \mathrm{Nd}_{(\mathrm{t})}=-3.5$ to -1.9 ); ca. $2.0 \mathrm{Ga}$ foliated granitoids $\left(\mathrm{T}_{\mathrm{DM}}\right.$ ages from 2.3 to $2.2 \mathrm{Ga} ; \varepsilon \mathrm{Nd}_{(\mathrm{t})}=-1.1$ to -0.8 ); ca. $1.98 \mathrm{Ga}$ hornblende diorite; ca. $1.97 \mathrm{Ga}$ metadiorite; ca. $1.97 \mathrm{Ga}$ phlogopite schist; ca. 1.98 to $1.95 \mathrm{Ga}$ monzogranite and granodiorite; ca. $1.97 \mathrm{Ga}$ foliated granites; ca. $1.89 \mathrm{Ga}$ leucomonzogranite, and ca. $1.79 \mathrm{Ga}$ porphyritic syenogranite, as well as 
gabbro and amphibolite of unknown ages $[2,27,63,112,132,136,141]$. The available TDM ages and $\varepsilon \mathrm{Nd}_{(\mathrm{t})}$ values suggest Paleoproterozoic mantle-derived magmas for the host rocks magmatic-forming processes. In addition, these rocks were often affected by N-S-, WNW-ESE- and E-W-striking $60-85^{\circ}$ dipping to all quadrants) faults.

Although the gold deposits and occurrences do not share the same spatial and paragenetic evolution concerning their hydrothermal alteration, it is notorious that albitic, potassic (K-feldspar \pm biotite), biotite-rich, carbonatic, sericitic-muscovitic, sericitic-chloritic, chloritic and propylitic alteration, and silicification are often over them $[27,29,136]$. It is noticed that temporal evolution started with the albitic alteration, followed by pervasive K-feldspar \pm biotite, biotitic, sericitic-muscovitic, and carbonatic alteration.

The ore-shoots are related to quartz \pm carbonate veins (Figure 7F), with proximal sericite, muscovite-sericite, biotite, and carbonate alteration halos. Such zones are distally enveloped by potassic (K-feldspar) alteration. The chlorite and propylitic alteration usually envelopes the previous hydrothermal zones on the regional scale $[27,136]$. Adularia-sericite and adularia-sericite-chlorite are present in banded veins, and adularia veinlets are also common. Furthermore, spaced-parallel veins with narrow halos of K-feldspar, chlorite, chlorite-epidote, epidote-quartz, epidote-sericite or quartz occur $[2,27,132,136]$.

The ore zones consist of massive to banded quartz \pm carbonate (calcite, ankerite, siderite) veins (up $1.5 \mathrm{~m}$ thick) with variable amounts of pyrite and chalcopyrite (Figure 7F), and minor molybdenite, galena, sphalerite, pyrrhotite, bornite, magnetite, hematite, scheelite, bismuthinite, native bismuth, $\mathrm{Te}-\mathrm{Bi}-\mathrm{Ag}$ alloys, monazite, xenotime, thorite, and barite inclusions. Such veins have albite and K-feldspar \pm quartz selvages and are hosted by fault-related foliated rocks with sericite-muscovite, chlorite, and carbonate alteration minerals. Gold ( $\mathrm{Au} / \mathrm{Ag}=4.2-20)$ occurs as sub-rounded inclusions in pyrite and subordinated in chalcopyrite (Figure 7G), or in fractures in sulfides [27,136,142].

Fluid inclusions assemblages in quartz from the gold-rich Paraíba and Edu occurrences (Figure 6B) reveal the coexistence of: (1) primary aqueous-carbonic $\left(\mathrm{H}_{2} \mathrm{O}-\mathrm{CO}_{2}-\mathrm{NaCl}\right)$ fluids with heterogeneity of fill degree (10-80\% $\mathrm{CO}_{2}$ liquid + vapor), low to high- salinity (1.6-22.0 wt.\% NaCl eq.), low to high homogenization temperatures $\left(159^{\circ} \mathrm{C}<\mathrm{T}<409^{\circ} \mathrm{C}\right)$ and $\mathrm{CO}_{2}$ melting temperatures $\left(\mathrm{T}_{\mathrm{mCO}}\right)$ from $-59.6{ }^{\circ} \mathrm{C}$ to $-56.6{ }^{\circ} \mathrm{C}$; (2) aqueous-carbonic $\left(\mathrm{H}_{2} \mathrm{O}+\mathrm{NaCl} \pm \mathrm{CO}_{2}\right)$ fluids with a variable filling degree (5-70\% vapor) and moderate temperatures $\left(212{ }^{\circ} \mathrm{C}<\mathrm{T}<244^{\circ} \mathrm{C}\right.$ ) and moderate to high salinities (3-27 wt.\% $\mathrm{NaCl}$ eq.); (3) aqueous $\left(\mathrm{H}_{2} \mathrm{O}-\mathrm{NaCl}-\mathrm{CaCl}_{2}\right)$ fluids with low to moderate temperatures $\left(79^{\circ} \mathrm{C}<\mathrm{T}<279^{\circ} \mathrm{C}\right)$ and salinities (2-16 wt.\% NaCl eq.); (4) halite-bearing aqueous $\left(\mathrm{H}_{2} \mathrm{O}-\mathrm{NaCl}-\mathrm{CaCl}_{2}\right)$ fluids of higher temperatures $\left(286{ }^{\circ} \mathrm{C}<\mathrm{T}<316^{\circ} \mathrm{C}\right), 37-43.5 \mathrm{wt} . \% \mathrm{NaCl}$ eq. $)$, and moderate to high temperatures $\left(286^{\circ} \mathrm{C}<\mathrm{T}<362^{\circ} \mathrm{C}\right)$; and minor 5) primary carbonic $\left(\mathrm{CO}_{2(\mathrm{~L})}+\mathrm{CO}_{2(\mathrm{~V})}\right)$ inclusions with $\mathrm{CO}_{2}$ melting temperatures from -57.5 to $-57^{\circ} \mathrm{C}[27,29,134]$.

The calcite stable isotope composition from Serrinha do Guarantã $\left(\delta^{13} \mathrm{C}=-2.6 \%\right.$ to $-2.4 \%$; and $\delta^{18} \mathrm{O}_{\mathrm{SMOW}}=+6.5 \%$ o to $+7.4 \%$ ) suggest magmatic-derived fluids [63].

The EMPA analysis on chlorite and white mica reveal a similar composition to that of the shallow-emplaced granite-hosted gold ore: clinochlore- to brunsvigite-type chlorite with $\mathrm{Fe} /(\mathrm{Fe}+\mathrm{Mg})$ ratios between 0.27 and 0.62 , and a muscovite-phengite trend towards the phengite-end member $\left(\mathrm{SiO}_{2}: 45.7-52.3 \mathrm{wt} . \% ; \mathrm{Al}_{2} \mathrm{O}_{3}: 24.8-32.7 \mathrm{wt} . \%\right)[63,112,136,143]$. The Ti contents in chlorite $(\leq 0.28 \mathrm{wt} . \%)$ indicate its hydrothermal origin. The chlorite geothermometer points to temperatures from $271^{\circ} \mathrm{C}$ to $360^{\circ} \mathrm{C}$ concerning the chlorite/propylitic alteration zones, whereas the pressure estimated by the phengite geobarometer ranges between 0.5 and $2.5 \mathrm{kbar}$ [137].

Trace element analyses of pyrite from the Edu occurrence, using LA-ICP-MS, indicate homogeneity in As (2.3-51.1 ppm) and Bi (0.8-53 ppm) contents, heterogeneity of $\mathrm{Cu}$ (2.7-2031 ppm) values and low content of invisible Au (up to $2.3 \mathrm{ppm}$ ) and Ag (up to $17 \mathrm{ppm}$ ) [113]. Additionally, performed EMPA trace elements of pyrite and chalcopyrite from the Edu and Paraíba ores. Gold concentrations are similar in the Paraíba (90-1740 ppm) and Edu (90-1150 ppm), besides the high concentrations of Ni (<65-1040 ppm) and Co 
(590-1920 ppm) in both cases. Reference [1] obtained a Pb-Pb age of $1841 \pm 22 \mathrm{Ma}$ for pyrite in equilibrium with chalcopyrite and magnetite from the Paraíba deposit.

\subsubsection{Epithermal Gold Veins}

The Francisco, Bigode and Luiz are the major occurrences of epithermal (chalcopyrite)galena-sphalerite-gold-quartz veins (Table S2, Supplementary Materials). Their host rocks are ca. $1.97 \mathrm{Ga}$ granodioritic porphyry, ca. $1.85 \mathrm{Ga}$ biotite granodiorite, ca. $1.77 \mathrm{Ga}$ syenogranitic to monzogranitic porphyries (Figure $7 \mathrm{H}$ ), and volcaniclastic feldspathic sandstone, feldspathic wacke, and lithic sandstone [23,27,75].

The sericitic-chloritic (sericite + quartz \pm chlorite) alteration envelopes the epithermal ore veins (Figure 7I), sometimes with adularia, and overprinted the early potassic (Kfeldspar \pm biotite) alteration. The propylitic alteration is distal and regional. Silicification and quartz infill are associated with veins, stockworks and breccias. Limited amounts of fine-grained alunite are related to intense silicification zones in the Francisco occurrence [76]. Pervasive argillic alteration (kaolinite + sericite + quartz) is also recognized. Furthermore, hematite veins crosscut all the previous hydrothermal alteration zones.

This type of gold mineralization occurs as massive to banded quartz veins with small geodes, breccias, and open space-filling textures, such as crustiform, zonal, colloform, cockade, vuggy, and comb (Figure 7J), suggesting their formation at relatively shallow levels. Moreover, platy calcite and quartz occur in veins (Figure 7K), especially in the Luiz occurrence $[23,27]$.

The ore is composed of pyrite, sphalerite, and galena, with subordinate chalcopyrite, digenite, bornite, pyrrhotite, hematite, magnetite, greenockite, rutile, apatite, monazite, and Bi-Te alloys, xenotime, aikinite, oxyallanite, hessite, and stutzite [23,27]. Gold $(\mathrm{Au} / \mathrm{Ag}=2.4-50)$ is restricted to pyrite, as small inclusions or as exsolved grains with galena in pyrite (Figure 7L).

Fluid inclusions assemblages in quartz from the Francisco occurrence include $\mathrm{CO}_{2}-$ free primary aqueous $\left(\mathrm{H}_{2} \mathrm{O}-\mathrm{NaCl}\right)$ fluids with heterogeneity in the degree of fill $(5-80 \%)$, low to moderate temperatures $\left(85^{\circ} \mathrm{C}<\mathrm{T}<288^{\circ} \mathrm{C}\right.$ ) and variable salinities $(6-24 \mathrm{wt} . \%$ $\mathrm{NaCl}$ eq) (Figure 6B). Moreover, monophase aqueous liquid- and vapor-rich inclusions also occur, however, in minor amounts. The estimated P-T conditions indicate the fluids were imprisoned at $0.74 \mathrm{kbar}$ ( $\sim 2 \mathrm{~km}$-deep) [76].

Chlorite has a dominantly brunsvigitic and minor ripidolite composition. The white mica from the sericitic halo of quartz gold veins has a composition between the muscovitephengite endmembers. The chlorite geothermometer yielded temperatures from $184{ }^{\circ} \mathrm{C}$ to $411^{\circ} \mathrm{C}[27]$.

Sulfur isotope compositions of pyrite $\left(\delta^{34} \mathrm{~S}=-2.6\right.$ to $\left.+1.4 \%\right)$, sphalerite $(-0.9$ to $+0.5 \%$ o , and galena $(-2.6$ to $+0.8 \%$ o $)$ were obtained for the Francisco occurrence. The calculated $\delta^{18} \mathrm{O}_{\mathrm{H} 2 \mathrm{O}}\left(+2.1\right.$ to $+3.4 \%$, at $\left.254.8{ }^{\circ} \mathrm{C}\right)$ and $\delta \mathrm{D}_{\mathrm{H} 2 \mathrm{O}}\left(-38\right.$ to $-42 \%$ ), at $254{ }^{\circ} \mathrm{C}$ (Figure $5 \mathrm{~B}$ ), values suggest external fluids of meteoric origin that may have interacted with magmatic water [76].

Furthermore, three sericite ${ }^{40} \mathrm{Ar}-{ }^{39} \mathrm{Ar}$ plateau ages from the sericite alteration of the Francisco occurrence vary from $1779 \pm 6.6 \mathrm{Ma}$ to $1777 \pm 6.4 \mathrm{Ma}$ [76], which are similar to the pyrite and molybdenite Re-Os ages constrained to granite-hosted occurrences previously described.

\section{Discussion}

\subsection{The Tectonic Setting of the Volcanic-Plutonic Associations of the TMP}

The tectonic evolution of the Tapajós and Juruena mineral provinces is not well understood, especially concerning the volcanic units that host epithermal gold-(polymetallic) mineralization. Their formation has been attributed both to anorogenic and continental magmatic arc settings $[1,3,8,40]$.

The previous tectonic models for the Amazonian Craton $[5,43,44,53]$ imply NW-SEtrending subduction zones and magmatic arcs. In the TMP, five magmatic arcs were 
proposed (ca. 2.01 Ga Cuiú-Cuiú island arc; ca. 1.97 to 1.95 Ga Cumaru and Creporizão continental magmatic arc; ca. 1.90 Ga Tropas island arc; ca. 1.89 Ga Parauari continental magmatic arc; [42]). Also, an NW-SE continuity of the Tapajós crust into the E-W-trending Juruena Province was admitted. However, the delimitation of geochronological (or tectonic) provinces is debatable. Consequently, tectonic evolution and metallogenetic zoning relationships are not well established, hampering the proposition of comprehensive mineral exploration models.

According to [54], the TMP was generated in an $\sim \mathrm{E}-\mathrm{W}$-oriented long-lived oceancontinent subduction event dipping to the north, probably with one flat-subduction stage $[56,59]$. This resulted in the building of at least two partially overlapped E-W-oriented continental plutonic/volcanic arcs caused by arc migration due to the oceanic plate dip variation at ca. 2.01 to $1.88 \mathrm{Ga}$. Considerable uplift and erosion within these two arcs are indicated by the juxtaposition of terrains from different crustal levels and discordances, exposing a crustal level from the plutonic environment to the Paleoproterozoic surface [15]. No evidence of collisional metamorphism, accreted island arcs, oceanic terrains, nor suture zones is observed in fieldworks. Post-orogenic to A-type volcanism and shallow-emplaced intrusions occur essentially along with great NW-SE and NE-SW-trending fault zones [60]. In this context, a lateral collision of the Juruena Province to the Tapajós Province caused by a roughly E-W-oriented north dip subduction would be possible $[53,58,77,78]$, but lack clear geological evidence yet.

This alternative tectonic model is consistent with the spatial zoning of magmatichydrothermal base metal and gold mineralization developed between ca. 2.0 and 1.88 Ga in the TMP. This zoning extends from the western TMP to the São Felix do Xingu region and suggests an origin in an E-W-trending Andean-type subduction zone with initial generation of calc-alkaline magmas, evolving to high-K calc-alkaline and finalizing with intraplate crustal melts. The spatial distribution of the arc-related mineralization would have been controlled by the subduction angle, which flattened [144] as the arc migrated northward until it stabilized, leading to the production of A-type magmas in the back-arc, as described in the Trans-Mexican Volcanic Belt [145-147] and the Andes [148-150].

The 2.0 Ga to $1.88 \mathrm{Ga}$ volcanic sequences are composed of andesite basalts to rhyolites, with the predominance of rhyodacites and rhyolites, defining extended high-K calc-alkaline series. Associated plutonic and subvolcanic rocks range from diorite to alkali-feldspar granites. Partially to intensively eroded volcanic calderas, ring and intracaldera volcanoes, resurgent dome, volcanic domes complexes, proximal to distal ignimbrite sequences, fissure-controlled volcanic and volcaniclastic rocks, hydrothermal pipes and dikes, volcanic breccias, agglomerates to ash tuffs, surge deposits, epiclastic volcaniclastic and fluvial, lacustrine, eolian and coastal deposits $[15,26,46,55,56,60,68,69,73]$ are present in the TMP, similarly to modern volcanic arcs.

These volcanic associations are typical of orogenic magmatism, where magmatichydrothermal systems are usually present. The intrusive rocks can be related to variable crustal level emplacement, varying from plutonic batholith to epizonal stocks and dikes of granophyre and porphyries, indicating an almost complete erosional cross-section. Supracrustal and plutonic rocks are juxtaposed through faults and erosional surfaces. This points to intense tectonic and erosional periods in the Paleoproterozoic, which was followed by long thermo-tectonic stability at the TMP after ca. $1.85 \mathrm{Ga}$, as evidenced by the ${ }^{40} \mathrm{Ar}-$ ${ }^{39} \mathrm{Ar}$ alunite spectra and Ar retention in alunite of the Botica Velha (V3) high-sulfidation epithermal Au-Ag mineralization, until the deposit unroofing at $51.3 \pm 0.1 \mathrm{Ma}[15,16]$. The late magmatism, typically fissure-controlled alkalic A-type, is similar to that of intra- and back-arc settings, produced in the final evolution stage of an orogenic belt.

\subsection{The Magmatic-Hydrothermal Gold-(Polymetallic) Systems of the TMP}

The correlation among the timing of arc magmatism, the $\mathrm{Pb}-\mathrm{Pb}$ sulfide ages [8], and Ar-Ar data for ore-related hydrothermal minerals (Figure 8), evidences a clear association between gold mineralization and magmatic (intrusive and extrusive) events in the TMP. 
The porphyry-like gold-(copper) mineralization (e.g., Palito; [100]; Tocantinzinho; $[24,25,30,31])$, as well as copper and molybdenum mineralization in the TMP, are well-defined by the shallow-crustal level of host rock emplacement, fluid inclusion data, metal content, hydrothermal mineral facies, zoning, temporal evolution, and magma fertility [55]. Their relationship with epithermal retrograde hydrothermal alteration is analogous to that of epithermal gold mineralization.

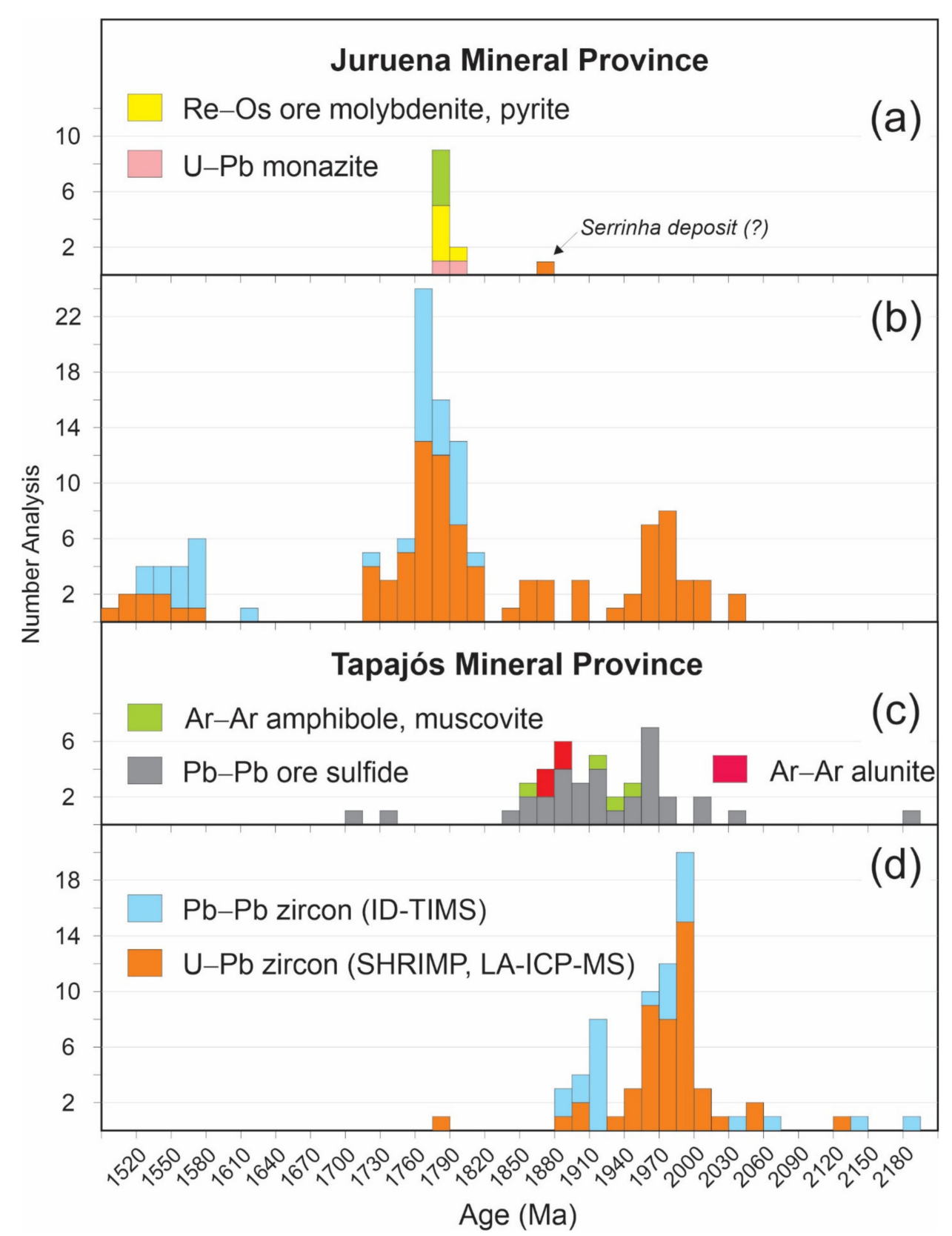

Figure 8. Geochronological data and distribution of magmatism and gold mineralization ages in the TPM and JMP. (a) Mineralization timing based on Re-Os molybdenite and chalcopyrite, Ar-Ar in muscovite/sericite, and U-Pb monazite ages from the JMP; (b) Magmatic events ages of the JMP; (c) Pb-Pb model ages for sulfides from TMP gold veins and alunite Ar-Ar ages from the Botica Velha (V3) high-sulfidation Au-Ag mineralization; (d) Magmatic events ages of the TMP. Data source: $[3,5,11,15,20,22,23,27,30,31,35,62,63,66,75,76,101,107,108,113,114,121-123,132,134,151]$.

The magmas associated with porphyry-like mineralization are predominantly I-type, oxidized (magnetite-bearing) high-K calc-alkaline or transitional to ilmenite-bearing granites, indicating magmas with distinct oxidation states. Usually, the hydrothermal paragene- 
sis of these magmatic-hydrothermal deposits reveals several pulses and variations on the oxygen fugacity and sulfur content in TMP.

More evolved, less oxidized high-K calc-alkaline granites could be represented by the Tocantinzinho gold deposit, which shares some characteristics of alkalic porphyry deposits [152] and Intrusion-Related Gold Systems (IRGS), in the conception of [153] and [154]. However, its hydrothermal alteration patterns (e.g., intense potassic, sericitic, propylitic alteration), and lack of copper association, in our conception, are likely related to the alkalic gold porphyry type deposits, as considered by [24,30].

Hydrothermal minerals associated with the Palito $\mathrm{Au}-(\mathrm{Cu})$ porphyry-like deposit have a similar isotope composition $\left(\delta^{18} \mathrm{O}_{\mathrm{H} 2 \mathrm{O}}=+7.2\right.$ to $-2.6 \%$; $\delta \mathrm{D}_{\mathrm{H} 2 \mathrm{O}}-55.4 \%$ to $+0.2 \%$, at 450 to $350{ }^{\circ} \mathrm{C}$; [100]) to those of typical calc-alkaline porphyry $\mathrm{Cu}-\mathrm{Au}-\mathrm{Mo}$ and related high-sulfidation epithermal deposits (Figure 5A). However, a significant contribution of early magmatic vapors and residual magmatic waters is suggested by isotope data.

Epithermal mineralization in the TPM includes the high-, intermediate- and lowsulfidation types $[15,16,22,26,35,107]$ hosted in volcanic breccias, rhyolite domes, plutonic, volcaniclastic, and sedimentary rocks (Figure 9). Hydrothermal alteration zoning, stable isotope data (Figure $5 \mathrm{~A}$ ) and noble $(\mathrm{He}, \mathrm{Ar}, \mathrm{Ne}$ ) gases in fluid inclusions and alunite crystals point to notable similarities of the ca. $1.87 \mathrm{Ga}$ Botica Velha (V3) Au-Ag mineralization to those of the typical high-sulfidation epithermal deposits, such as Tambo, in the El Indio-Pascua belt, Chile $[15,16,102]$.

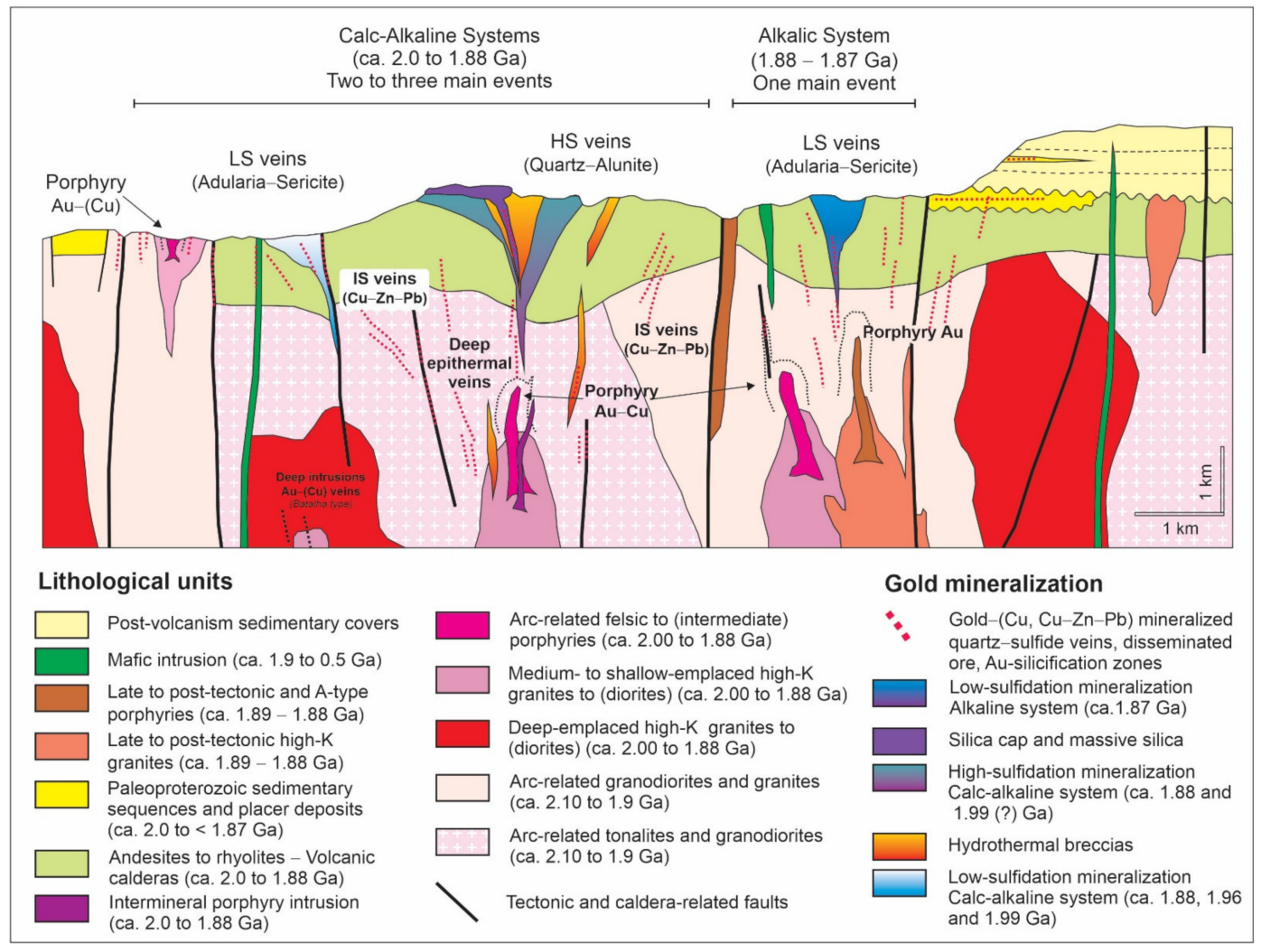

Figure 9. A conceptual model for the gold deposits in the TMP. At the JMP, gold deposits were formed in younger episodes than those of the TMP, but as part of a similar magmatic-hydrothermal system.

In the intermediate-sulfidation $\mathrm{Au}-\mathrm{Ag}-(\mathrm{Cu}-\mathrm{Pb}-\mathrm{Zn})$ deposits (e.g., Coringa), as well as some low-sulfidation occurrences, the hydrothermal fluid source and mixing trend defined by $\mathrm{H}-\mathrm{O}$ stable isotopes $\left(\delta^{18} \mathrm{O}_{\mathrm{H} 2 \mathrm{O}}=+9.8\right.$ to $-1.8 \% ; \delta \mathrm{D}_{\mathrm{H} 2 \mathrm{O}}=-92 \%$, at 400 to $234{ }^{\circ} \mathrm{C}$; Reference [35] data are similar to that of the Botica Velha (V3) high-sulfidation $\mathrm{Au}-\mathrm{Ag}$ mineralization (Figure 5A). In the intermediate-sulfidation deposits, these data suggest primary neutralization $[96,106]$ of the original acid magmatic fluid by reaction with 
the host rocks during the migration around the magmatic intrusion, followed by mixing with meteoric fluids. Low-sulfidation gold epithermal occurrences associated with the tardi- to post-orogenic to A-type magmatism may also be related to alkalic epithermal systems in the São Félix do Xingu area, east of the TMP [32].

The main difference between the magmatic-hydrothermal fluids related to ca. $1.97 \mathrm{Ga}$ and $1.88 \mathrm{Ga}$ deposits of the TMP with modern arc-related systems is the magmatic fluid evolution towards low-latitude meteoric waters (Figure 5A). This trend is interpreted as due to intense evaporated surficial waters [155]. In the nearby São Felix do Xingu area, ca. $1.88 \mathrm{Ga}$ cross-bedding calcarenites with layers of mud-cracks with marks of anhydrite/gypsum, as well several dissection structures in sedimentary rocks, is compatible with the interpreted fluid mixing and evolution.

The magmatic fluid participation and mixing processes with meteoric water characterized in the ca. $1.97 \mathrm{Ga}$ and $1.88 \mathrm{Ga}$ high-, intermediate-, and low-sulfidation $\mathrm{Au}-(\mathrm{Ag})$ epithermal mineralization associated with hydrothermal breccias (in volcanic crater and dikes) are also identified for thick quartz-(sulfide) veins and stockworks. These veins are hosted in tectonic and volcanic structures, crosscutting all rock types in shallow to relatively deep crustal levels. Hydrothermal breccias are common within the gold-mineralized veins. The veins present variable amounts of sulfides and are pyrite-rich to polymetallic, with associated Mn-calcite in the intermediate-sulfidation epithermal deposits. Veinlets to massive sulfide veins are frequent, including gold-rich chalcopyrite veins (up to $3.5 \mathrm{~kg} / \mathrm{t}$ of $\mathrm{Au}$ ).

Gold-mineralized quartz, quartz-sulfide or sulfide veins hosted in the deeper intrusive rocks are predominantly associated with brittle or brittle-ductile faults close to subvolcanic to plutonic intrusions (e.g., Cuiú-Cuiú gold camp; $[9,108,121,122])$. Fluid inclusion data indicate evolution from immiscibility of a magmatic aqueous-carbonic fluid, generating high-salinity brines (up to $30 \mathrm{wt} . \% \mathrm{NaCl}$ and $410{ }^{\circ} \mathrm{C}$ ) and $\mathrm{CO}_{2}$-only fluids, followed by mixing with meteoric fluids [121] (Figure 6A). Stable isotope data (S, O, D) is also consistent with magmatic fluid and sulfur sources $[8,101,121]$ (Figure 5A).

These veins could be interpreted as the roots of epithermal systems (Figure 9), as described by [156] for deeper epithermal systems. Alternatively, the deeper veins could be related to fluids exsolved from high- $\mathrm{f}_{\mathrm{H} 2 \mathrm{O}}$ granites emplaced in a deeper level than that typical of porphyry type deposit formation, releasing fluid along with rock discontinuities, mainly faults, as exemplified by $[18,157]$. This mineralization type was correlated to the Korean-type gold mineralization [1], which occurs below epithermal veins in the Korean Peninsula. However, according to $[158,159]$, these deeper veins in Korea are genetically linked to the magmatic-hydrothermal epithermal systems, as proposed here.

The preserved erosional level, from the Paleoproterozoic surface to an intermediate crustal level, the sin- to post-depositional rift and pull-apart volcano-sedimentary basins, and the presence of some small calc-alkaline porphyry-like hydrothermal systems (e.g., Palito; $[28,38,40,100])$ indicate an exploratory potential for $\mathrm{Au}, \mathrm{Cu}$ and Mo in the TMP. In addition, the later felsic alkalic shallow-emplaced intrusions and the common extensive propylitic, sericitic-chloritic, sericitic and potassic (biotite or biotite + microcline) sulfide-rich hydrothermal alteration with retrograde argillic, adularia, silicic, and carbonate alteration suggests a potential to alkalic gold-only or $\mathrm{Au}-\mathrm{Cu}$ porphyry mineralization similar to those of the Cadia and Northparkes districts, Australia [152,160,161]. At Cadia and Northparkes, the island arc setting result in prevalent oceanic mafic-intermediate magmatism, whereas intermediate-felsic rocks formed in continental arc predominate in the TMP and JMP. Despite differences in arc-related units and ages, the macroscopic lithological aspects, geochemistry, hydrothermal alteration patterns, including the characteristic reddish potassic altered rocks, and intrusion morphology (e.g., "pencil" intrusions) are very similar between these Australian and Brazilian gold mineralization types. 


\subsection{Relationship between Orogenic and Magmatic-Hydrothermal Gold Deposits in the TMP: A Critical Evaluation}

The proposition of the orogenic model for the gold veins in the Tapajós and Juruena provinces $[1,8-10,101,109]$ has been based on: (i) control by faults and shear zones, (ii) deep crustal level of the host rocks, mainly granitoids, sometimes interpreted as submitted to amphibolite facies metamorphism, and amphibolites, perhaps considered as metavolcanic rocks; (iii) low-salinity aqueous-carbonic fluid inclusions in quartz, which define pressure $(0.86$ to $3.0 \mathrm{~kb}$ ) reaching up to $7 \mathrm{~km}$ deep in the crust, and (iv) carbonate alteration.

The hydrothermal fluid origin commonly was attributed to deep crustal, metamorphic sources $[9,10]$. However, a magmatic fluid contribution is admitted $[90,109]$, as aqueouscarbonic fluids have highly variable salinity, usually $<7 \mathrm{wt} . \% \mathrm{NaCl}$ eq., ranging from 1.6 to 21 wt. $\% \mathrm{NaCl}$ eq $[9,10,90,101,108,121,122]$ (Figure 6). Reference [99] indicated the possibility of magmatic-derived fluids in the genesis of orogenic gold deposits. However, the importance of pelitic, basaltic and oceanic sequences as the source for orogenic gold and fluids by metamorphic devolatilization is emphasized [162-165]. Similar geological units are not present in the TMP, as well as typical regional metamorphic zones or large ductile shear zones. Volcanic and other supracrustal units underwent zeolite/prehnitepumpellyite metamorphism. Brittle to brittle-ductile fault zones are discontinuous, with gold mineralization spatially related to felsic intrusions.

Intermediate- to high-saline aqueous fluid inclusions in restrict parts of less deformed quartz in structurally-controlled sulfide-quartz veins ( $>20$ to $30 \mathrm{wt} . \% \mathrm{NaCl}$ eq.; [9,109], at the Palito mine (up to $50 \% \mathrm{NaCl}$ eq. in quartz from the potassic alteration zones; [28]) and the Tocantinzinho deposit (up to $21.4 \% \mathrm{NaCl}$ eq.; [24]) (Figure $6 \mathrm{~A}$ ) precludes an orogenic origin, as summarized by [99]. In addition, low- to intermediate-salinities are also typical of epithermal veins. The high $\mathrm{CO}_{2}$ content in fluids could be related to the roots of epithermal veins or more alkaline granite magmas [166]. According to [167], salinity estimates in fossil epithermal systems are in error when based on ice melting temperature without an independent $\mathrm{CO}_{2}$ content measurement. Misinterpretation of fluid inclusion freezing could result in large errors for the interpreted physicochemical environment. Carbonic gas is also highlighted as a common component in low-salinity fluids from fossil epithermal precious metal mineralization. In this case, deeper gold mineralized veins hosted in granites cannot be surely correlated with orogenic gold deposits based only on low-salinity and $\mathrm{CO}_{2}$ contents.

Available $\mathrm{O}$ and $\mathrm{H}$ stable isotope data for minerals and fluid inclusion (Figure 5A) do not indicate a typical correlation with orogenic gold deposits. Instead, fluids that crystallized alunite and associated hydrothermal minerals of the Botica Velha (V3) highsulfidation mineralization are similar to those compiled for worldwide high-sulfidation deposits, which have significant participation of magmatic-hydrothermal brines. Data from fluid inclusions interpreted as evidence of an orogenic "mesothermal to epizonal" origin [8] show good agreement with ore-forming fluids in high-sulfidation deposits, indicating a magmatic source and mixing with low-latitude meteoric water, in minor proportion, as before defined by [15]. Similar fluid source and fluid mixing processes are observed for all epithermal, porphyry-like and undifferentiated "intrusion-related or orogenic" gold mineralization in the TMP (Figure 5A).

Gold veins hosted by deeper granites tend to exhibit a higher formation pressure (up to $7 \mathrm{~km}$ deep), where a porphyry system starts its evolution; [88] with a minor meteoric contribution. Veins hosted in volcanic-volcaniclastic rocks are formed in the shallow crustal environment and show a greater meteoric contribution. Magmatic source for the hydrothermal fluids in TMP has been characterized for all veins formed in the two or more mineralizing episodes, in temporal agreement with the major magmatic episodes (Figure 8), but without any correlation with metamorphic events, reinforcing this interpretation.

The structural control is clear in most gold-bearing quartz-sulfide veins, but undoubted mylonites are restricted (e.g., Ouro Roxo; $[109,122])$ and associated with mica-rich hydrothermal mineral assemblages, indicating synchronous or post-mineralization de- 
formation. In fact, at TMP, deformation overprinting is usual in quartz veins, ores and hydrothermally altered rocks, resulting in undulated extinction, fracturing and recrystallization of quartz and sulfides, and strong foliated hydrothermal mica-rich vein halo zones. The presence of NW-SE-oriented ductile shear zones in the TMP has yet to be proven, but NW-SE, NE-SW, and E-W-striking brittle faults are widespread, several of them hosting gold lodes. Hydrothermal breccias, open-fill structures, banding, druses in vugs, and late carbonate infills are frequently associated with gold mineralized veins considered as related to orogenic "mesothermal" processes $[8,10,101,168]$. Although hydrothermal breccia formation is possible in a relatively high-pressure environment, fluid inclusion isochores point to depths up to $7 \mathrm{~km}$. In such a crustal environment, open-space filling textures and breccias are unlike $[169,170]$. In this case, the possibility of hydrostatic overpressure caused by the release of large fluid volumes from magma intrusions and the low permeability of country rocks may be considered [171].

The relatively deeper ore formation environment inferred for the TMP gold mineralized veins is based on fluid inclusion barometry, indicating crustal level deeper than expected to porphyry deposits $(<5 \mathrm{~km})$. However, $[171,172]$ demonstrated that fluid inclusion isochores in porphyry systems with fluid immiscibility define higher pressures than those based on geological evidence.

Overpressured to pressured hydrothermal fluids occur typically at deep of $3 \mathrm{~km}$ (or less than $1.5 \mathrm{~kb}$ ) due to a seal of a relatively impermeable unit (e.g., shales or diagenetically cemented sandstone) or by lateral sealed steeply dipping fault zones by several processes, including thermal expansion [173]. High $\mathrm{CO}_{2}$ volumes in fluid inclusions in quartz from veins at the TMP could also point to a sealed and overpressured hydrothermal system up to above the lithostatic pressure, which resulted in episodic hydrothermal breccias.

Although non-lithostatic overpressure is controversial, well-documented evidence regarding crustal evolution, geothermobarometry, tectonism and metamorphism cases confirm this phenomenon. Overpressure would be provoked by non-hydrostatic thermodynamics, deviatoric stress, strength contrasts, tectonic mode switching, and autoclave processes [174]. Extreme events of uplift and erosion, pull apart sedimentary basins and large fault zones, which contributed to preserving the volcanic units and juxtapose deepand shallow-emplaced rocks, indicate a significant compressional event in the TMP. The Amazonian Craton crust is thick, with an average of $38.1 \mathrm{~km}$, and relatively thicker (up to $42 \mathrm{~km}$ ) at the south of the Amazonas basin, where the TMP is located [175]. In such conditions, flexural and horizontal stresses in the upper crust under the brittle regime, similar to those environments of gold mineralization formation, could result in hydrostatic pressure two times higher than the lithostatic pressure value [176]. Major faults controlled different magma intrusion phases and hosted gold- and base metal mineralized veins in the TMP. Water-rich magmas should be consolidated in a deeper crustal level than those typical of porphyry emplacement, releasing hydrothermal fluids through fault channels, as represented by the Batalha granite mineralization at TMP [18]. If hydrothermal minerals seal the fault, fluid overpressure could be reached, explaining the relatively high-pressure of entrapment defined by fluid inclusions studies in quartz veins with textures typical of shallow crustal levels.

Pyrite $(\leq 3-5 \%)$ is the main gold host mineral, arsenopyrite and pyrrhotite are common, and carbonates are subordinated $(\leq 5-15 \%)$ in orogenic gold lodes [162,177]. Gold veins in the TMP do not present arsenopyrite, pyrrhotite is scarce, and chalcopyrite, sphalerite, galena, molybdenite and sulfosalt minerals are usual. Massive sulfide veins and the correlation of gold content with copper (up $>1.5 \%$ ) are very common. In the Palito mine, massive chalcopyrite veins (up to $1 \mathrm{~m}$-thick) could be very gold-rich. These characteristics appear to be more compatible with magmatic-hydrothermal systems rather than orogenic deposits. In addition, no siderite or ankerite is present in gold veins; instead, later calcite is the typical carbonate, and occasionally as platy calcite. Mn-calcite is frequent in polymetallic veins, commonly associated with sericite and minor adularia or alunite, as is typical of intermediate-sulfidation epithermal mineralization [106]. Finally, the hy- 
drothermal alteration types (potassic (K-feldspar + biotite or biotite), sericitic, propylitic, argillic, adularia-sericite, alunite-quartz), styles, and zoning are not consistent with those of orogenic gold deposits. They are similar to those observed in epithermal veins, in the root of epithermal or in porphyry systems, from shallow to deep levels $[97,166,178,179]$.

Besides typical cataclastic textures in granites and foliation in hydrothermally altered mica-rich rocks in faults, no medium to high-grade regional metamorphism deformation affected older tonalites, granodiorites, and minor granites [1,5,8,42]. Instead, the described textures, structures and mineralogy are more likely magmatic and representative of thermal effects on contacts, roof pendant and enclaves. Typical migmatites are present, but in small volumes, inside the tonalite, granodiorite, and granite bodies, apparently representing enclaves. In this case, no source appears to be present to the metamorphic fluid generation in the TMP.

Collectively, the geological environment, structural control, geochronology, and stable isotope and fluid inclusion data suggest major importance of magmatic-hydrothermal processes in the TMP, instead of orogenic gold deposits, with good examples of wellpreserved high-, intermediate- and low-sulfidation epithermal, and porphyry-like gold mineralization associated with high-K calc-alkaline granites. However, we do not discharge the existence of orogenic gold mineralization in more eroded units, although this type of gold mineralization in the TMP needs more data to be better constrained.

\subsection{Gold Metallogeny in the Juruena Mineral Province}

The primary gold occurrences in the JMP exhibit a close spatial relationship with calc-alkaline and oxidized (magnetite-bearing) I-type granites, volcanic rocks, and volcanosedimentary sequences originated in continental magmatic arcs. The hydrothermal alteration, styles, and the ore paragenesis, together with fluid inclusions and isotopic data, suggest their formation in Paleoproterozoic magmatic-hydrothermal systems developed in different crustal levels and positions regarding the magmatic source. The JMP has been tectonically juxtaposed to TMP between 1.69 to $1.63 \mathrm{Ga}$ through a roughly E-W-trending shear zone [53].

Collectively, the granite-hosted gold disseminated and veins exhibit zonation and paragenetic evolution of the hydrothermal alteration pattern with early albite alteration $\left(\delta^{18} \mathrm{O}=8.5-9.4 \%\right.$ ) , followed by K-feldspar $\left(\delta^{18} \mathrm{O}=8.2-10.1 \%\right.$ ) , sericite/muscovite + quartz + pyrite $\left(\delta^{18} \mathrm{O}=6.6-8.8 \%\right.$ and $\delta \mathrm{D}=-63$ to $-34 \%$ ), silicification and silica-infill, calcite, regional propylitic and chloritic alteration $\left(\delta^{18} \mathrm{O}=4.3-5.1 \%\right.$ and $\delta \mathrm{D}=-55$ to $-52 \%$ o). The estimated fluid isotopic signature $\left(\delta^{18} \mathrm{O}_{\mathrm{H} 2 \mathrm{O}}=+2.2 \%\right.$ to $+8.2 \%$; $\delta \mathrm{D}_{\mathrm{H} 2 \mathrm{O}}=-5.1 \%$ o to $-42 \%$, at $209-458{ }^{\circ} \mathrm{C}$ ) equilibrated to phyllosilicates (e.g., muscovite and sericite) strongly suggests magmatic mineralizing fluids [20,38,62,76] (Figure 5B).

Moreover, the radial fine-grained muscovite in granite-hosted gold-rich ore zones and fault-hosted veins, as well as the moderate to high-temperature $\mathrm{H}_{2} \mathrm{O}-\mathrm{CO}_{2}-\mathrm{NaCl}$ fluids, indicate magmatic degassing into deeper porphyry-like systems [76,180]. Nevertheless, the pressure conditions ( $0.7-3.6 \mathrm{kbar}$ ) estimated by fluid inclusions are dissimilar to those expected for arc-related magmatic-hydrothermal systems, as porphyry deposits. Such conditions might represent hydrostatic overpressure caused by large fluid volume discharged by magmas emplaced at shallower levels than $3.6 \mathrm{kbar}$, in a similar way as considered for TMP deeper gold veins. Alternatively, pressure estimates are unreliable due to the effects of heterogeneous fluid entrapment [171,172], as observed by [172] regarding the excessively high pressures calculated from fluid inclusions for most porphyry-copper deposits.

On the other hand, the sulfide-gold veins in faults and shear zones are hosted in ca. 2.7-1.98 granitic-tonalitic basement, ca. 2.0 foliated granite, 2.05-1.95 Ga granitoids, and $1.79 \mathrm{Ga}$ porphyritic syenogranite. The ore zones comprise essentially disseminated to massive pyrite and chalcopyrite in banded to massive quartz \pm carbonate veins housed in faults and shear zones. Such veins are capped by sericitic-quartz alteration, gradually overprinted by radial muscovite \pm sericite, biotite-rich, and late carbonate alteration. These alterations are centered into potassic alteration, in a first stage as K-feldspar-rich, and 
then as biotite-rich $[27,136]$, which exbibit a regional envelope of propylitic and chloritic alteration. Adularia-sericite and adularia-sericite-chlorite alteration are also present, as well as adularia veinlets. Furthermore, spaced-parallel veins with chlorite, chloriteepidote, epidote-quartz, epidote, sericite, or quartz, often with pyrite \pm chalcopyrite, exhibit narrow K-feldspar halos [2,27,132,136].

The proximal sericitic, sericitic-chloritic, and carbonatic alteration stages are mainly parallel to subparallel to the foliation, syn- to post-deformation and overprinted tectonic fault reactivation. Additionally, late idiomorphic gold-free pyrite overprints the restricted sericite-quartz mylonite zones of the Edu deposit [11].

The $\mathrm{H}_{2} \mathrm{O}-\mathrm{CO}_{2}$-rich fluids could be derived from metamorphic dehydration reactions, commonly responsible for fluid generation in orogenic gold deposits $[99,165,181]$. However, $\mathrm{CO}_{2}$-rich fluids can also be released by deep or alkaline granites, as pointed out by $[153,182]$, or in epithermal systems [167]. Since no evidence for alkaline A-type magmatism has been constrained on the fault-hosted gold veins, such fluids might be sourced from deeper granodiorite-tonalite bodies. Such fluids could reflect magmatic immiscibility processes [38,112], possibly linked to the root of magmatic-hydrothermal systems. Moreover, the saline fluids (up to $27 \mathrm{wt} . \% \mathrm{NaCl}$ eq.; Figure 6B), in coexistence with these aqueous-carbonic fluids, represent additional evidence to magmatic-sourced rather than metamorphic-derived fluids, as previously discussed for TMP. The unique available stable isotope data for these gold occurrences, obtained from hydrothermal calcite of the Serrinha de Guarantã deposit [63], also indicate a magmatic signature for the mineralizing fluids $\left(\delta^{13} \mathrm{C}=-2.6 \%\right.$ to $-2.4 \%$; and $\delta^{18} \mathrm{O}_{\mathrm{SMOW}}=+6.5 \%$ o to $+7.4 \%$ o $)$.

Although an orogenic gold model has been advocated for such structurally-controlled gold veins [183], their descriptive geological features converge to a magmatic-hydrothermal genesis. Such features include: (i) low volume of metamorphic host rocks (e.g., gneisses), in contrast to the larger volume of undeformed and not metamorphosed ca. 1.97-1.95 Ga calc-alkaline, oxidized I-type granites and porphyries; (ii) absence of metamorphic paragenesis outer to the hydrothermal halos; (iii) their paragenetic hydrothermal evolution (e.g., K-feldspar, biotite, sericite, sericite-adularia, radial coarse-grained muscovite, late calcite, chlorite, and regional propylitic); (iv) the coexistence of medium- to high-saline and $\mathrm{CO}_{2}$-rich fluids (Figure 6B); and (v) the carbon and oxygen isotopic signature of calcite. Since copper is not a significant metal in the Intrusion-related gold systems [153,154], such features are more consistent with the roots of magmatic-hydrothermal systems than orogenetic gold deposits. These features are similar to those here reported for the structurally-controlled gold deposits in the TMP. Therefore, it is suggested that porphyrylike gold deposits correspond to a more coherent model for them. However, these deposits and occurrences in JMP are possibly older than those reported to granite-hosted ore and polymetallic-veins occurrences at ca. $1.78 \mathrm{Ga}$.

The 1.78-1.77 Ga epithermal polymetallic-veins, nevertheless, are hosted by ca. 2.0 arc-derived volcano-sedimentary sequences, ca. $1.97 \mathrm{Ga}$ high-evolved calc-alkaline Itype granitic porphyry, 1.86 Ga granites, and 1.77 Ga monzogranitic-syenogranitic porphyries. Such occurrences share hydrothermal alteration patterns spatially related to the ca. $1.78-1.77$ Ga porphyry dikes and rhyolitic lavas $[27,38,76]$. The calculated isotope fluid compositions in equilibrium with hydrothermal minerals representative of the paragenetic evolution attest to magmatic and volcanic sources with important input of meteoric water (Figure $5 \mathrm{~B})$, from the potassic $\left(\delta^{18} \mathrm{O}_{\mathrm{H} 2 \mathrm{O}}=+8.4\right.$ to $+9.7 \%$, at $\left.254{ }^{\circ} \mathrm{C}\right)$, to sericitic $\left(\delta^{18} \mathrm{O}_{\mathrm{H} 2 \mathrm{O}}\right.$ $=+2.1$ to $+3.4 \%$ and $\delta \mathrm{D}_{\mathrm{H} 2 \mathrm{O}}=-42$ to $-35 \%$ ), argillic, silicic alteration and silica infill $\left(\delta^{18} \mathrm{O}_{\mathrm{H} 2 \mathrm{O}}=+3.9\right.$ to $\left.+4.6 \%\right)$, and propylitic alteration. Open space-filling textures corroborate the fluid circulation into shallow crustal levels (ca. $0.7 \mathrm{kbar}$ ), whereas the predominantly heterogeneous aqueous fluid regime indicates boiling processes. Additional boiling evidence corresponds to bladed quartz, platy calcite, and rarer well-crystallized adularia in quartz and Mn-calcite quartz veins from the Pezão and Luiz occurrences, as pointed out by [27]. Local alunite is restricted to highly-silicified rocks, indicating high-oxidized mineralizing fluid stages. Collectively, such features suggest low- to intermediate-sulfidation 
epithermal systems, especially considering the paragenesis with pyrite, galena, sphalerite, chalcopyrite and Mn-calcite, with restricted alunite and adularia.

Collectively, the wide occurrence of undeformed tonalites, granodiorites and granites, but minor microgranites, porphyries, volcanic rocks, and fault and shear zones that affected the basement nuclei and ca. 2.05-1.96 Ga granites suggest higher erosive levels in JMP than those observed at TMP. That might have implied in exposing deeper crustal levels, up to the roots of porphyry systems, and therefore, the granite-hosted gold veins could represent distal vein generated in porphyry systems in JMP.

The magmatic crystallization ages span from 2.05 to $1.77 \mathrm{Ga}$, indicating a prolonged magmatic activity, individualized into three extensive Paleoproterozoic events: (1) 2.05$1.93 \mathrm{Ga}$ Orosirian arc-like event, answerable for mantle-derived granite-tonalite magmas; (2) 1.90-1.80 Ga Late Orosirian I-type event, responsible for the major crustal growth in the province with the production of $1.90 \mathrm{Ga}$ adakite-like magmas; and (3) 1.79-1.77 Ga Statherian post-orogenic to intracratonic onset, with the formation of later volcanic rocks, porphyries, and I- to A-type evolved granites [58,76,77].

The 2.05-1.90 Ga magmatic events, grouped into the Peixoto de Azevedo Domain $[58,77,78]$, have been attributed as an extension of the TMP under the Cachimbo graben toward the JMP. However, it would imply a southward continuity of the TMP, crosscutting the clear E-W tectonic trend of the Juruena Province [53,77], which hosts the most known gold deposits and occurrences in JMP. This appears to be geologically inappropriate if the Juruena province was juxtaposed to the Tapajós Province due to a later $(1.69-1.63 \mathrm{Ga})$ lateral continental collision [27,53]. Alternatively, these older rocks in the JMP would be better explained as: (i) a basement core in the Juruena continental magmatic, chronocorrelate to the Cuiú-Cuiú Complex; (ii) an imbricated tectonic slab (e.g., a klippe) of the TMP into the JMP due to the collision event; or (iii) a part of the TMP moved from west to the actual position by a later dextral fault along with the contact between the provinces.

The Re-Os sulfide and ${ }^{40} \mathrm{Ar}-{ }^{39} \mathrm{Ar}$ ages concerning the disseminated gold and polymetallic-veins occurrences indicate a single ca. 1.78 Ga Statherian gold event into the Juruena Province, thus, chronocorrelate to highly-evolved I-type magmas from the third magmatic event, responsible for the emplacement of fine-grained porphyritic granites, porphyries and volcanic rocks, belonging to the ca. 1.81 to $1.78 \mathrm{Ga}$ Colíder Group. It points out the importance of porphyry-related magmatic-hydrothermal activity within the province, aided by regional structures for large-scale magmatic-hydrothermal circulation, as corroborated by the often presence of hydrothermally altered and sulfide-bearing porphyries in all occurrences and prospects. However, it is not discarded the possibility of gold events older than $1.78 \mathrm{Ga}$, especially if considered the ca. 1.97-1.95 Ga calc-alkaline shallow-emplaced (sub-volcanic) porphyry intrusions in the Luiz and Paraíba deposits [27], and in the fault-controlled occurrences, for which the hydrothermal activity seems to have been syn- to post deforming processes. However, additional information on petrography, geochronology and isotopic composition on hydrothermal minerals are crucial for better constraining such occurrences. The main gold mineralization in the TMP (ca. 1.88), related to calc-alkaline magmatism, and in the JMP (ca. $1.78 \mathrm{Ga}$ ), point to important differences between both provinces and in relation to the interpreted extension of TMP into JMP.

Additionally, the often presence of fine-grained granite, aplite and mafic to intermediate volcanic dikes over the gold-rich occurrences, affected by hydrothermal processes, can be interpreted as intermineral epizonal intrusions, such as those often observed in Andean arc-related porphyry gold systems [88,184]. At JMP, such intrusions (granite to syenite and diorite to fine-grained gabbro) vary in ages from 1.78 to $1.77 \mathrm{Ga}$ and commonly have disseminated to vein-type pyrite \pm chalcopyrite $[27,29,79,81]$. This epizonal magmatism could have supplied the mineralizing magmatic-hydrothermal system with vapor, sulfur, and heat. Furthermore, such magmatism might suggest a magmatic event occurred during a post-orogenic extension, related to high-evolved I-type magmatism from the third magmatic event that took place in the JMP [76]. 
The 1.78-1.77 Ga gold event in the JMP might have been triggered by the 1.8-1.77 Ga post-orogenic magmatism, possibly related to the thickening of the Juruena magmatic arc. Into this scenario, the asthenospheric upwelling may have caused a second stage of melting of a relatively Au-rich residue in the lower crust and lithospheric mantle produced after the first stage melting during the Arc-type magmatism. This process might produce high $\mathrm{Au} / \mathrm{Cu}$ ratios in magmas due to the dissolution of Au-rich residue, producing postsubduction Au-rich porphyry and epithermal systems [185]. Such processes might be the geodynamic key for understanding the reasons why the JMP hosts copper-poor and goldrich hydrothermal occurrences of high- to medium-grade and low tonnage gold deposits, as pointed out by [134].

\section{Conclusions}

The review, systematization and new geologic, petrological, and metallogenetic data of the TMP and JMP presented in this paper indicate Paleoproterozoic episodes of magmatichydrothermal mineralization in continental magmatic arcs as the main source for gold, despite the possibility of orogenic gold deposits and the Paleoproterozoic Castelo de Sonhos modified paleoplacer.

A summary of the gold metallogenesis in the TMP, and also in JMP, which records different ages for the magmatism and mineralization, is presented in Figure 9. Epithermal and porphyry mineralization are important sources for gold $[88,184,185]$, but the preservation of epithermal systems, due to the near-surface formation and regional metamorphism, is not expected in old terrains, as the Paleoproterozoic TMP and JMP. The exceptional preservation of high-, intermediate- and low-sulfidation epithermal systems, the large and growing identification of a number of these hydrothermal deposits, and the extensive distribution of these occurrences in the TMP point to an unexplored potential for highgrade veins in volcanic/volcaniclastic and shallow- to deep-emplaced granites. Despite the relatively deeper erosion in part of the JMP, there is also a potential for epithermal gold deposits in volcanic/volcaniclastic sequences and associated with faults in granites.

The exposition of plutonic and volcanic units formed in at least three continental magmatic arcs in both provinces, together with porphyry-like hydrothermal systems, also point to the potential for low-grade and large volume $\mathrm{Au}-(\mathrm{Cu})-(\mathrm{Mo})$ deposits associated with arc-related to post-orogenic magmatism, including alkalic porphyry gold deposits. Some distinct characteristics of these porphyry-like systems, as thicker veins and less intense hydrothermal fracturing, should be better understood since this could be related to Paleoproterozoic geologic processes in the TMP and JMP.

The magmatic-hydrothermal systems involved variable oxygen fugacity of hydrothermal fluids and intrusive compositions, from diorites to alkali-feldspar granites in all magmatic arcs, but more evolved I-type and K-rich calc-alkaline rocks predominate, favoring gold deposit potential. The amount of produced gold, mineralized alluvial and eluvial/colluvial deposits and primary occurrences show a huge potential for economic magmatic-hydrothermal gold deposits in both provinces.

In addition, the relationship among more primitive magmas with high-sulfidation $\mathrm{Au}-\mathrm{Ag}$ mineralization, $\mathrm{Mo}$ and $\mathrm{Pb}-\mathrm{Zn}-\mathrm{Cu}-(\mathrm{Ag})$ intermediate-sulfidation mineralization, and a large number of chalcopyrite-bearing mineral occurrences highlight the possibility of occurrence of porphyry base metal mineralization in both provinces, including $\mathrm{Cu}-\mathrm{Au}$ alkalic porphyries, yet not explored, in the TMP and JMP.

Identifying the fertile magmatic suites, the delimitation of the magmatic, and a better understanding of magmatic-hydrothermal epochs will be critical in future works to support mineral exploration in both provinces.

Supplementary Materials: The following are available online at https:/ /www.mdpi.com/article/10.339 0/min11070714/s1, Table S1: Main attributes of Au-(base metal) deposits of the Tapajós Mineral Province (TMP). Abbreviations after [92], except Bs = bismuthinite; $\mathrm{Hd}$ = hedleyte; $\mathrm{Hs}=$ hessite; $\mathrm{Lu}=$ luzonite; $\mathrm{Wt}=$ wittichenite, Table S2: Main attributes of major Au-(base metal) occurrences, targets, and deposits from Juruena Mineral Province. Abbreviations after [92], except Hs = hessite; Tv = tivanite; Wuf = wulfenite. Ref- 
erences [3,5,8-10,14-16,18,22,24-26,31,34,35,66,90,92,100,101,103,104,107-110,116,117,120-127,129,130,151] and $[1,2,11,20,23,27,33,62,63,76,92,111-113,132,134-136,141]$ are cited in supplementary materials, in Tables S1 and S2, respectively.

Author Contributions: Conceptualization, C.J., R.R.d.A. and L.V.S.M.; Methodology, C.J., R.R.d.A., L.V.S.M. and C.M.D.F.; software, J.E.Z.d.S.M., L.V.S.M. and R.R.d.A.; validation, C.J. and L.V.S.M.; formal analysis, C.J. and L.V.S.M.; investigation, C.J., R.R.d.A., L.V.S.M., C.M.D.F. and J.E.Z.d.S.M.; writing-original draft preparation, C.J., R.R.d.A., L.V.S.M., C.M.D.F., J.E.Z.d.S.M. and J.R.C.eC.; writing-review and editing, C.J. and L.V.S.M. All authors have read and agreed to the published version of the manuscript.

Funding: PRONEX/CNPq (Grant number 103/98 Proc. 66.2103/1998-0), CAPES—Coordenação de Aperfeiçoamento de Pessoal de Nível Superior, Brazil (Grant number 0096/05-9), and CNPqConselho Nacional de Desenvolvimento Científico e Tecnológico, Brazil (Grants numbers 573733/20082, 555066/2006-1, 306130/2007-6, 475164/2011-3, 550342/2011-7, 505851/04, 310864/2014-3, and 309645/2018-2), and FAPESP (Grant number 98/02567/6) provided funding for researches.

Data Availability Statement: Not applicable.

Acknowledgments: The authors are grateful to: Rio Tinto, Serabi, Chapleau-Magellan, Mapex, Anglo American, Belo Sun, Nexa, Brazil Resources, PA Gold, Rio Novo Gold, Ajax, Aura Mineral, and Companhia Matogrossense de Mineração mining companies, and the Cooperativa de Garimpeiros do Vale do Rio do Rio Peixoto for supporting field works; to student Victor Matheus Pantoja Soares (UFPA) for help with literature data collecting; and to CAPES-Coordenação de Aperfeiçoamento de Pessoal de Nível Superior (Brazil) for the research scholarship granted to Jhoseph Ricardo Costa e Costa. The authors also thank to the Guest Editor Lydia Lobato, and to the anonymous reviewers for their contributions that greatly improved the text.

Conflicts of Interest: The authors declare no conflict of interest.

\section{References}

1. Santos, J.O.S.; Groves, D.I.; Hartmann, L.A.; Moura, M.A.; McNaughton, N.J. Gold deposits of the Tapajós and Alta Floresta domains, Tapajós-Parima Orogenic Belt, Amazon Craton, Brazil. Miner. Depos. 2001, 36, 278-299. [CrossRef]

2. Paes de Barros, A.J. Contribuição à geologia e controle das mineralizações auríferas de Peixoto de Azevedo-MT. Master's Thesis, Universidade de São Paulo, Sao Paulo, Brazil, 1994.

3. Lamarão, C.N.; Dall'Agnol, R.; Lafon, J.-M.; Lima, E.F. Geology, Geochemistry, and Pb-Pb zircon geochronology of the Paleoproterozoic magmatism of Vila Riozinho, Tapajós Gold Province, Amazonian Craton, Brazil. Precambrian Res. 2002, 119, 189-223. [CrossRef]

4. Lamarão, C.N.; Dall'Agnol, R.; Pimentel, M.M. Nd isotopic composition of Paleoproterozoic volcanic and granitoid rocks of Vila Riozinho: Implications for the crustal evolution of the Tapajós Gold Province, Amazon Craton. J. S. Am. Earth Sci. 2005, 18, 277-292. [CrossRef]

5. Santos, J.O.S.; Hartmann, L.A.; Gaudette, H.E.; Groves, D.I.; McNaughton, N.J.; Fletcher, I.R. A new understanding of the provinces of the Amazon Craton based on integration of field mapping and $\mathrm{U}-\mathrm{Pb}$ and $\mathrm{Sm}-\mathrm{Nd}$ geochronology. Gondwana Res. 2000, 3, 453-488. [CrossRef]

6. Dall'Agnol, R.; Costi, H.T.; Leite, A.A.d.S.; de Magalhães, M.S.; Teixeira, N.P. Rapakivi granites from Brazil and adjacent areas. Precambrian Res. 1999, 95, 9-39. [CrossRef]

7. Dall'Agnol, R.; Teixeira, N.P.; Ramo, O.T.; Moura, C.A.V.; Macambira, M.J.B.; Oliveira, D.C. Petrogenesis of the Paleoproterozoic Rapakivi A-Type Granites of the Archean Carajás Metallogenic Province, Brazil. Lithos 2005, 80, 101-129. [CrossRef]

8. Coutinho, M.G.N.; Souza, E.C.; Guimarães, M.T.; Liverton, T.; Walsh, J.N. Petrologia e geoquímica das rochas hospedeiras. In Provincia Mineral do Tapajós: Geologia, Metalogênia e Mapa Provisional Para ouro em SIG; Coutinho, M.G.N., Ed.; CPRM: Rio de Janeiro, Brazil, 2008; pp. 137-196.

9. Klein, E.L.; Rosa Costa, L.T.; Carvalho, J.M. Estudo de inclusões fluidas em veio de quartzo aurífero do prospecto Patinhas, Província Aurífera do Tapajós, Cráton Amazônico. Rev. Bras. Geociências 2004, 34, 59-66. [CrossRef]

10. Klein, E.L.; Santos, R.A.; Fuzikawa, K.; Angélica, R.S. Hydrothermal fluid evolution and structural control of the brittle-style Guarim lode-gold mineralisation, Tapajós Province, Amazonian Craton, Brazil. Miner. Depos. 2001, 36, 149-164. [CrossRef]

11. Paes de Barros, A.J. Granitos da Região de Peixoto de Azevedo-Novo Mundo e mineralizações auríferas relacionadas, Província Aurífera Alta Floresta (MT). Ph.D. Thesis, Universidade Estadual de Campinas, Campinas, Brazil, 2007.

12. Nunes, C.M.D.; Juliani, C.; Corrêa-Silva, R.H.; Bettencourt, J.S.; Jacobi, P. Paleoproterozoic quartz-alunite epithermal gold mineralization from Tapajós (Brazil). In Proceedings of the 31st International Geological Congress Special Symposia and General Symposia - Abstract Volume, Rio de Janeiro, Brazil, 6-17 August 2000. IUGS/CPRM, [CD-ROM]. 
13. Juliani, C.; Nunes, C.M.D.; Bettencourt, J.S.; Corrêa-Silva, R.H.; Monteiro, L.V.S.; Neumann, R.; Alcover Neto, A.; Rye, R.O. Early Proterozoic volcanic-hosted quartz-alunite epithermal deposits in the Tapajós Gold Province, Amazonian Craton, Brazil. In Proceedings of the Geological Society of America Meeting-Abstracts with Programs, Geological Society of America; Geological Society of America, Reno, NV, USA, 9-18 November 2000; Volume 32, p. A-49.

14. Jacobi, P. The discovery of epithermal Au-Cu-Mo Proterozoic deposits in the Tapajós Province, Brazil. Rev. Bras. Geociências 1999, 29, 277-279. [CrossRef]

15. Juliani, C.; Rye, R.O.; Nunes, C.M.D.; Snee, L.W.; Correa Silva, R.H.; Monteiro, L.V.S.; Bettencourt, J.S.; Neumann, R.; Neto, A.A. Paleoproterozoic high-sulfidation mineralization in the Tapajós Gold Province, Amazonian Craton, Brazil: Geology, mineralogy, alunite argon age, and stable-isotope constraints. Chem. Geol. 2005, 215, 95-125. [CrossRef]

16. Landis, G.P.; Snee, L.W.; Juliani, C. Evaluation of argon ages and integrity of fluid-inclusion compositions: Stepwise noble gas heating experiments on 1.87 Ga alunite from Tapajós Province, Brazil. Chem. Geol. 2005, 215, 127-153. [CrossRef]

17. Botelho, N.F.; Moura, M.A. Granite-ore deposit relationships in Central Brazil. J. S. Am. Earth Sci. 1998, 11, 427-438. [CrossRef]

18. Juliani, C.; Correa-Silva, R.H.; Monteiro, L.V.S.; Bettencourt, J.S.; Nunes, C.M.D. The Batalha Au-granite system-Tapajós Gold Province, Amazonian Craton, Brazil: Hydrothermal alteration and regional implications. Precambrian Res. 2002, 119, 225-256. [CrossRef]

19. Moura, M.; Botelho, N. Petrologia po magmatismo associado à mineralização do tipo ouro pórfiro da Província Aurífera Juruena-Teles Pires (MT). Rev. Bras. Geociências 2002, 32, 377-386. [CrossRef]

20. Moura, M.A.; Botelho, N.F.; Olivo, G.R.; Kyser, T.K. Granite-gelated Paleoproterozoic, Serrinha gold deposit, Southern Amazonia, Brazil: Hydrothermal alteration, fluid inclusion and stable isotope constraints on genesis and evolution. Econ. Geol. 2006, 101, 585-605. [CrossRef]

21. Sillitoe, R.H. The tops and bottoms of porphyry copper deposits. Econ. Geol. 1973, 68, 799-815. [CrossRef]

22. Aguja-Bocanegra, M.A. Mineralizações Epitermal Low-Sulfidation e do Tipo Pórfiro Superpostas Associadas ao Magmatismo Félsico de 1,88 Ga na Parte Norte da Província Mineral do Tapajós (PA). Master's Thesis, Universidade de São Paulo, São Paulo, Brazil, 2013.

23. Assis, R.R.d. Depósitos Auríferos Associados ao Magmatismo Granítico do Setor Leste da Província de Alta Floresta (MT), Craton Amazônico: Tipologia das Mineralizações, Modelos Genéticos e Implicações Prospectivas. Master's Thesis, Universidade de Campinas, Campinas, Brazil, 2011.

24. Lopes, A.A.; Moura, M.A. The Tocantinzinho Paleoproterozoic porphyry-style gold deposit, Tapajós Mineral Province (Brazil): Geology, petrology and fluid inclusion evidence for ore-forming processes. Minerals 2019, 9, 29. [CrossRef]

25. Santiago, É.S.B.; Villas, R.N.; Ocampo, R.C. The Tocantinzinho Gold Deposit, Tapajós Province, state of Pará: Host granite, hydrothermal alteration and mineral chemistry. Braz. J. Geol. 2013, 43, 185-208. [CrossRef]

26. Tokashiki, C.C.; Juliani, C.; Monteiro, L.V.S.; Misas, C.M.E.; Aguja, M.A.; Arrais, L.B. Eventos vulcânicos de 1,97 Ga com mineralizações de ouro epitermais low- e intermediate-sulfidation na porção sul da Província Mineral do Tapajós (PA). In Contribuições à Geologia da Amazônia; Gorayeb, P.S.S., Lima, A.M.M., Eds.; Sociedade Brasileira de Geologia-Núcleo Norte (SBG-NNN): Belém, Brazil, 2015; Volume 9, pp. 119-138.

27. Trevisan, V.G. Estudo Comparativo Entre Mineralizações Filonares de Au $\pm \mathrm{Cu}$ e Au + Metais de Base do Setor Leste da Província de Alta Floresta (MT), Cráton Amazônico. Master's Thesis, Universidade Estadual de Campinas, Campinas, Brazil, 2015.

28. Usero, G.; Juliani, C.; Bello, R.D.S.; Echeverri-Misas, C.M.; Tommasini, D.; Monteiro, L.V.S. Estudo das inclusões fluidas da mineralização paleoproterozoica de $\mathrm{Au}-(\mathrm{Cu})$ do tipo pórfiro do Palito, Província Aurífera do Tapajós (PA). In Contribuições à Metalogenia do Brasil; Frantz, J.C., Marques, J.C., Jost, H., Eds.; UFRGS/Instituto de Geociências: Porto Alegre, Brazil, 2011; Volume 1, pp. 111-128.

29. Assis, R.R.D.; Xavier, R.P.; Paes de Barros, A.J.; Barbuena, D.; Trevisan, V.G.; Ramos, G.S.; Teixeira, R.V.; Miguel Júnior, E.; Rodrigues, R.M.; Stabile Júnior, A.; et al. Depósitos de Au e Au + metais de base associados a sistemas graníticos paleoproterozóicos do setor leste da Província de Alta Floresta (MT), Cráton Amazônico. In Metalogenia das Províncias Tectônicas Brasileiras; Silva, M.G., Neto, M.B.R., Jost, H., Kuyumjian, R.M., Eds.; CPRM: Belo Horizonte, Brazil, 2014; p. 589.

30. Biondi, J.C.; Borgo, A.; Chauvet, A.; Monié, P.; Bruguier, O.; Ocampo, R. Structural, mineralogical, geochemical and geochronological constraints on ore genesis of the gold-only Tocantinzinho deposit (Pará State, Brazil). Ore Geol. Rev. 2018, 102, 154-194. [CrossRef]

31. Borgo, A.; Biondi, J.C.; Chauvet, A.; Bruguier, O.; Monié, P.; Baker, T.; Ocampo, R.; Friedman, R.; Mortensen, J. Geochronological, geochemical and petrographic constraints on the Paleoproterozoic Tocantinzinho gold deposit (Tapajós Gold Province, Amazonian Craton-Brazil): Implications for timing, regional evolution and deformation style of its host rocks. J. S. Am. Earth Sci. 2017, 75, 92-115. [CrossRef]

32. Cruz, R.S.; Fernandes, C.M.D.; Villas, R.N.N.; Juliani, C.; Monteiro, L.V.S.; Lagler, B.; Misas, C.M.E. Paleoproterozoic volcanic centers of the São Félix do Xingu region, Amazonian Craton, Brazil: Hydrothermal alteration and metallogenetic potential. J. Volcanol. Geotherm. Res. 2016, 320, 75-87. [CrossRef]

33. Galé, M.G.; da Costa, P.C.C.; Assis, R.R.d.; Pinho, F.E.C.; Juliani, C. Estudo de inclusões fluidas em quartzo do Garimpo do Papagaio, um sistema magmático-hidrotermal, Província Aurífera de Alta Floresta (MT), Cráton Amazônico. Geol. USP Série Científica 2018, 18, 207. [CrossRef] 
34. Gómez-Gutiérrez, D.F. Petrogênese e Metalogenia do Magmatismo Paleoproterozoico na Porção sul da Província Mineral do Tapajós, Cráton Amazônico. Ph.D. Thesis, Universidade de São Paulo, São Paulo, Brazil, 2018.

35. Guimarães, S.B.; Klein, E.L.; Harris, C.; Costa, I.S.L. Metallogenesis of the Orosirian epithermal Coringa Gold-Silver (Cu-Pb-Zn) deposit, Southeastern Tapajós Mineral Province, Amazonian Craton, Brazil. Ore Geol. Rev. 2021, 128, 103908. [CrossRef]

36. Juliani, C. Epithermal and porphyry mineralization potential in well preserved Paleoproterozoic (ca. 2.0 to $1.78 \mathrm{Ga}$ ) continental magmatic arcs in the Amazonian Craton, Brazil. In Proceedings of the SEG 2019: Conference South American Metallogeny: Sierra to Craton, Society of Economic Geologist, Santiago, Chile, 7-10 October 2019.

37. Jamasmie, C. Anglo American 'Encouraged' by Drilling Results from Copper Asset in North Brazil. Available online: https: //www.mining.com/anglo-american-encouraged-drilling-results-copper-asset-north-brazil (accessed on 20 January 2021).

38. Bettencourt, J.S.; Juliani, C.; Xavier, R.P.; Monteiro, L.V.S.; Bastos Neto, A.C.; Klein, E.L.; Assis, R.R.; Leite Júnior, W.B.; Moreto, C.P.N.; Fernandes, C.M.D.; et al. Metallogenetic systems associated with granitoid magmatism in the Amazonian Craton: An overview of the present level of understanding and exploration significance. J. S. Am. Earth Sci. 2016, 68, 22-49. [CrossRef]

39. Juliani, C.; Monteiro, L.V.S.; Fernandes, C.M.D. Potencial mineral: Cobre. In Recursos Minerais no Brasil: Problemas e Desafios; Melfi, A.J., Misi, A., Campos, D.d.A., Cordani, U.G., Eds.; Academia Brasileira de Ciências: Rio de Janeiro, Brazil, 2016; Volume 1, pp. 134-154.

40. Juliani, C.; Vasquez, M.L.; Klein, E.L.; Villas, R.N.N.; Echeverri-Misas, C.M.; Santiago, E.S.B.; Monteiro, L.V.S.; Carneiro, C.C.; Fernandes, C.M.D.; Usero, G. Metalogenia da Província Tapajós. In Metalogênese das Províncias Tectônicas Brasileiras; Silva, M.G., Rocha Neto, M.G., Jost, H., Kuyumajian, R.M., Eds.; CPRM—Serviço Geológico do Brasil: Belo Horizonte, Brazil, 2014; Volume 1, pp. 229-268.

41. Villas, R.N.N.; Santos, M. Gold Deposits of the Carajás Mineral Province: Deposit types and metallogenesis. Miner. Depos. 2001, 36, 300-331. [CrossRef]

42. Santos, J.O.S.; Van Breemen, O.B.; Groves, D.I.; Hartmann, L.A.; Almeida, M.E.; McNaughton, N.J.; Fletcher, I.R. Timing and evolution of multiple Paleoproterozoic magmatic arcs in the Tapajós Domain, Amazon Craton: Constraints from SHRIMP and TIMS zircon, baddeleyite and titanite U-Pb Geochronology. Precambrian Res. 2004, 13, 73-109. [CrossRef]

43. Tassinari, C.C.G.; Macambira, M.J.B. Geochronological Provinces of the Amazonian Craton. Episodes 1999, 22, 174-182. [CrossRef]

44. Tassinari, C.C.G.; Macambira, M.J.B. A evolução tectônica do Craton Amazônico. In Geologia do Continente Sul Americano: Evolução da Obra de Fernando Flávio Marques Almeida; Mantesso-Neto, V., Bartorelli, A., Carneiro, C.D.R., Brito Neves, B.B., Eds.; BECA: São Paulo, Brazil, 2004; pp. 471-486.

45. Vasquez, M.L.; Rosa-Costa, L.T. Geologia e Recursos Minerais do Estado do Pará: Sistema de Informações Geográficas-SIG: Texto Explicativo dos Mapas Geológico e Tectônico e de Recursos Minerais do Estado do Pará, 1st ed.; CPRM-Serviço Geológico do Brasil: Belém, Brazil, 2008; ISBN 978-85-7499-065-1.

46. Lagler, B.; Juliani, C.; Fernandes, C.M.D.; da Cruz, R.S.; Vieira, D.A.S. Paleoproterozoic volcanic caldera in the Amazonian Craton, northern Brazil: Stratigraphy, lithofacies characterization, and lithogeochemical constraints. J. S. Am. Earth Sci. $2019,95,102252$. [CrossRef]

47. Bomfim, E.P.; Braitenberg, C.; Molina, E.C. Mutual evaluation of global gravity models (EGM2008 and GOCE) and terrestrial data in Amazon Basin, Brazil. Geophys. J. Int. 2013, 195, 870-882. [CrossRef]

48. Bongiolo, A.B.S. Contribuição ao Estudo da Bacia do Amazonas e seu Embasamento Através da Magnetometria e Gravimetria, Curitiba, Brazil, 2011. Ph.D. Thesis, Universidade Federal do Paraná, Curitiba, Brazil, 2011. Available online: https: / / acervodigital.ufpr.br/handle/1884/26906 (accessed on 26 November 2020).

49. Caputo, M.V. Stratigraphy, Tectonics, Paleoclimatology and Paleogeography of Northern Basins of Brazil. Ph.D. Thesis, University of California, Santa Barbara, CA, USA, 1984.

50. Nunn, J.A.; Aires, J.R. Gravity anomalies and flexure of the lithosphere at the middle Amazon Basin, Brazil. J. Geophys. Res. 1988, 93, 415-428. [CrossRef]

51. Almeida, F.F.M. Origem e evolução da Plataforma Brasileira. Boletim do Departamento de Produção Mineral Divisão de Geologia e Mineralogia. Boletim 1967, 241, 1-36.

52. Amaral, G. Geologia Pré-Cambriana da região Amazônica. Ph.D. Thesis, Universidade de São Paulo, São Paulo, Brazil, 1974.

53. Scandolara, J.E.; Correa, R.T.; Fuck, R.A.; Souza, V.S.; Rodrigues, J.B.; Ribeiro, P.S.E.; Frasca, A.A.S.; Saboia, A.M.; Lacerda Filho, J.V. Paleo-Mesoproterozoic arc-accretion along the southwestern margin of the Amazonian Craton: The Juruena accretionary orogen and possible implications for Columbia supercontinent. J. S. Am. Earth Sci. 2017, 73, 223-247. [CrossRef]

54. Carneiro, C.d.C.; Juliani, C.; Carreiro-Araújo, S.A.; Monteiro, L.V.S.; Crósta, A.P.; Fernandes, C.M.D. New crustal framework in the Amazon Craton based on geophysical data: Evidences of deep east-west trending suture zones. IEEE Geosci. Remote Sens. Lett. 2019, 16, 20-24. [CrossRef]

55. Cassini, L.V.; Moyen, J.-F.; Juliani, C. Orosirian magmatism in the Tapajós Mineral Province (Amazonian Craton): The missing link to understand the onset of Paleoproterozoic tectonics. Lithos 2020, 356-357, 105350. [CrossRef]

56. Fernandes, C.M.D.; Juliani, C.; Monteiro, L.V.S.; Lagler, B.; Echeverri-Misas, C.M. High-K calc-alkaline to A-type fissure-controlled volcano-plutonism of the São Félix do Xingu region, Amazonian Craton, Brazil: Exclusively crustal sources or only mixed Nd model ages? J. S. Am. Earth Sci. 2011, 32, 351-368. [CrossRef]

57. Kroonenberg, S.B.; Roever, E.W.F.d. Geological Evolution of the Amazonian Craton. In Amazonia: Landscape and Species Evolution; Hoorn, C., Wesselingh, F.P., Eds.; Wiley-Blackwell Publishing Ltd.: Oxford, UK, 2011; pp. 7-28. 
58. Rizzotto, G.J.; Alves, C.L.; Rios, F.S.; Barros, M.A.d.S. The Western Amazonia Igneous Belt. J. S. Am. Earth Sci. $2019,96,102326$. [CrossRef]

59. Fernandes, C.M.D.; Juliani, C. The tectonic controls on the Paleoproterozoic volcanism and the associated metallogeny in the south Amazonian Craton, Brazil: Sr-Nd-Pb isotope constraints. Precambrian Res. 2019, 331, 105354. [CrossRef]

60. Juliani, C.; Fernandes, C.M.D. Well-preserved Late Paleoproterozoic volcanic centers in the São Félix do Xingu region, Amazonian Craton, Brazil. J. Volcanol. Geotherm. Res. 2010, 191, 167-179. [CrossRef]

61. Vasquez, M.L.; Castro, J.M.R.d.; Chaves, C.L.; da Costa Neto, M.C.; Cruz, V.L. Mapa Geológico e de Recursos Minerais da Província Mineral do Tapajós_Escala 1: 500.000 2020; CPRM—Serviço Geológico do Brasil: Belém, Brazil, 2020. Available online: http: //rigeo.cprm.gov.br/jspui/handle/doc/18638 (accessed on 20 November 2020).

62. Galé, M.G. Gênese das Mineralizações Associadas ao Magmatismo Ácido na Região do Garimpo do Papagaio, Noroeste da Província Aurífera de Alta Floresta (MT). Ph.D. Thesis, Universidade de São Paulo, São Paulo, Brazil, 2018.

63. Rios, F.S. O Depósito de $\mathrm{Au}(\mathrm{Cu}-\mathrm{Ag})$ Serrinha de Guarantã, Cráton Amazônico, Brasil: Um Depósito Aurífero Não-Convencional Associado ao Sistema Pórfiro-Epitermal Paleoproterozoico Juruena-Teles Pires. Master's Thesis, Universidade de Brasília, Brasília, Brazil, 2019.

64. Juliani, C.; Fernandes, C.M.D.; Monteiro, L.V.S.; Misas, C.M.E.; Lagler, B. Possível zonamento metalogenético associado ao evento vulcano-plutônico de 2,0 a 1,88 Ga na parte sul do Cráton Amazônico. In Proceedings of the II Simpósio Brasileiro de Metalogenia, Gramado, Brazil, 7-10 June 2009. Universidade Federal do Rio Grande do Sul [CD-ROM].

65. Juliani, C.; Monteiro, L.V.S.; Bettencourt, J.S.; Fernandes, C.M.D. Epithermal and porphyry-related Au and base-metal mineralization in the Paleoproterozoic Uatumã magmatism-Tapajós Gold Province, Amazonian Craton. In Proceedings of the 33rd International Geological Congress, Oslo, Norway, 6-14 August 2008. IUGS [CD-ROM].

66. Echeverri-Misas, C.M. Geologia e Alteração Hidrotermal nas Rochas Vulcânicas e Plutônicas Paleoproterozoicas na Porção sul da Província Mineral do Tapajós (PA). Ph.D. Thesis, Universidade de São Paulo, São Paulo, Brazil, 2015.

67. Gómez-Gutiérrez, D.F.; Juliani, C.; Cassini, L.V. Petrografia e geoquímica das vulcânicas félsicas na porção sul da Província Mineral do Tapajós (PA). In Proceedings of the XIII Simpósio de Geologia da Amazônia, Marabá, Brazil, 20-30 September 2015; Sociedade Brasileira de Geologia, SBG/Núcleo Norte [CD-ROM]: Belém, Brazil.

68. Roverato, M.; Giordano, D.; Giovanardi, T.; Juliani, C.; Polo, L. The 2.0-1.88 Ga Paleoproterozoic evolution of the southern Amazonian Craton (Brazil): An interpretation inferred by lithofaciological, geochemical and geochronological Data. Gondwana Res. 2019, 70, 1-24. [CrossRef]

69. Roverato, M.; Juliani, C.; Fernandes, C.M.D.; Capra, L. Paleoproterozoic andesitic volcanism in the southern Amazonian Craton, the Sobreiro Formation: New insights from lithofacies analysis of the volcaniclastic sequences. Precambrian Res. 2017, 289, 18-30. [CrossRef]

70. Freitas, B.; Juliani, C. Guia de Texturas Macroscópicas e Microscópicas e de Estruturas de Rochas Vulcânicas Brasileiras Antigas da Amazônia; E-book Series; Universidade de São Paulo, Instituto de Geociências: São Paulo, Brazil, 2018; Volume 70, Available online: http:/ / www.livrosabertos.sibi.usp.br/portaldelivrosUSP/catalog/book/295 (accessed on 20 November 2020). [CrossRef]

71. Oliveira, R.G. Insights on the framework of the Carajás Province, Amazonian Craton, Brazil, and on the three-dimensional shape of the Carajás Basin, based on gravity data. J. Geol. Surv. Braz. 2018, 1, 101-112. [CrossRef]

72. Neder, R.D.; Leite, J.A.D.; Figueiredo, B.R.; McNaughton, N.J. 1.76 Ga volcano-plutonism in the southwestern Amazonian Craton, Aripuanã-MT, Brazil: Tectono-stratigraphic implications from SHRIMP U-Pb zircon data and rock geochemistry. Precambrian Res. 2002, 119, 171-187. [CrossRef]

73. Kunifoshita, A.M.U.; dos Santos, F.H.; Motta, J.G. Reconstruction of the effusive and explosive deposits of the Aruri and Salustiano formations in the Tapajós Domain, southern Amazonian Craton, from field relationship, petrography and geochemistry. J. S. Am. Earth Sci. 2021, 107, 103095. [CrossRef]

74. Souza, J.P.; Frasca, A.A.S.; Oliveira, C.C. Geologia e Recursos Minerais da Província Mineral de Alta Floresta, 1st ed.; CPRM-Serviço Geológico do Brasil: Brasília, Brazil, 2005.

75. Miguel Júnior, E. Controle Estrutural das Mineralizações Auríferas e Idades U-Pb das Rochas Encaixantes ao Longo do lineamento Peru-Trairão: Província Aurífera de Alta Floresta, Mato Grosso. Master's Thesis, Universidade Estadual de Campinas, Campinas, Brazil, 2011.

76. Assis, R.R.d. Depósitos Auríferos Associados ao Magmatismo Félsico da Província de Alta Floresta (MT), Cráton Amazônico: Litogeoquímica, Idade das Mineralizações e Fonte dos Fluidos. Ph.D. Thesis, Universidade Estadual de Campinas, Campinas, Brazil, 2015.

77. Alves, C.L.; Rizzotto, G.J.; Rios, F.S.; Gonçalves, G.F. Áreas de Relevante Interesse Mineral—Evolução Crustal e Metalogenia da Província Mineral Juruena-Teles Pires. Informe de Recursos Minerais, Série Provincias Minerais do Brasil, No 22, 1st ed.; Alves, C.L., Rizzoto, G.J., Rios, F.S., Gonçalves, G.F., Eds.; CPRM—Serviço Geológico do Brasil: Goiânia, Brazil, 2019; Volume 22, ISBN 978-85-7499-547.

78. Alves, C.L.; Rizzotto, G.J.; Rios, F.S.; de Sant-Ana Barros, M.A. The Orosirian Cuiú-Cuiú magmatic arc in Peixoto de Azevedo Domain, southern of Amazonian Craton. J. S. Am. Earth Sci. 2020, 102, 102648. [CrossRef]

79. Duarte, T.B. Geologia, Geoquímica e Geocronologia do Domínio Vulcânico do Arco Magmático Juruena, SW do Cráton Amazônico: Implicações Geotectônicas. Master's Thesis, Universidade Estadual de Campinas, Campinas, Brazil, 2015.

80. Silva, M.G.; Abram, M.B. Projeto Metalogenia da Província Aurífera Juruena-Teles Pires, Mato Grosso, 1st ed.; CPRM-Serviço Geológico do Brasil: Goiânia, Brazil, 2008. 
81. Moura, M.A. O maciço Granítico Matupá e o Depósito de Ouro Serrinha (MT): Petrologia, Alteração Hidrotermal e Metalogenia. Ph.D. Thesis, Universidade de Brasília, Brasília, Brazil, 1998.

82. Pimentel, M.M. Resultados Geocronológicos do Projeto PROMIN Alta Floresta. Unpublished Report; Laboratório de Geocronologia, IG, Universidade de Brasília: Brasília, Brazil, 2001.

83. Pinho, M.A.S.B.; Lima, E.F.; Fetter, A.; Van Schmus, W.R.; Chemale Júnior, F. Caracterização petrográfica e dados geocronológicos preliminares das rochas vulcânicas da Formação Iriri-Porção centro-sul do Cráton Amazônico, Aripuanã, Mato Grosso. Rev. Bras. Geociências 2001, 31, 1-5. [CrossRef]

84. Pessoa, M.R.; Andrade, A.F.; Nascimento, J.O.; Santos, J.O.S.; Oliveira, J.R.; Lopes, R.C.; Prazeres, W.V. Projeto Jamanxim; Ministério das Minas e Energia, DNPM/CPRM: Manaus, Brazil, 1977.

85. Coutinho, M.G.d.N.; Robert, F.; dos Santos, R.A. A first approach in understanding the gold mineralization of Tapajós Mineral Province, Amazonian area, Brazil. In Proceedings of the 10th International Gold Symposium; Minérios \& Minerales, Rio de Janeiro, Brazil, 29-30 September 1997.

86. Sillitoe, R.H. Intrusion-related gold deposits. In Gold Metallogeny and Exploration; Foster, R.P., Ed.; Blackie: Glasgow, Scotland, 1991; pp. 165-209.

87. Sillitoe, R.H.; Steele, G.B.; Thompson, J.F.H.; Lang, J.R. Advanced argillic lithocaps in the Bolivian Tin-Silver Belt. Miner. Depos. 1998, 33, 539-546. [CrossRef]

88. Sillitoe, R.H. Porphyry copper systems. Econ. Geol. 2010, 105, 3-41. [CrossRef]

89. Juras, S.; Gregersen, S.; Alexander, R. Technical Report for the Tocantinzinho Gold Project, Brazil; Eldorado Gold Corporation: Vancouver, BS, Canada, 2011.

90. Borges, A.W.G. Geologia e Metalogênese do Depósito Aurífero São Jorge, Província Aurífera do Tapajós, Novo Progresso, PA. Master's Thesis, Universidade Federal do Pará, Belém, Brazil, 2010.

91. Lipman, P.W. The roots of ash flow calderas in western North America: Windows into the tops of granitic batholiths. J. Geophys. Res. 1984, 89, 8801-8841. [CrossRef]

92. Whitney, D.L.; Evans, B.W. Abbreviations for names of rock-forming minerals. Am. Mineral. 2010, 95. [CrossRef]

93. Stoffregen, R.E.; Rye, R.O.; Wasserman, M.D. Experimental studies of alunite. II: ${ }^{18} \mathrm{O}-{ }^{16} \mathrm{O}$ and D-H fractionation factors between alunite and water at $250-450{ }^{\circ} \mathrm{C}$. Geochim. Cosmochim. Acta 1994, 58, 903-916. [CrossRef]

94. Taylor, H.P. Oxygen and hydrogen isotope relationships in hydrothermal mineral deposits. In Geochemistry of Hydrothermal Ore Deposits; Barnes, H.L., Ed.; John Wiley \& Sons: New York, NY, USA, 1997; Volume 1, pp. 229-302.

95. Giggenbach, W.F. The origin and evolution of fluids in magmatic-hydrothermal systems. In Geochemistry of Hydrothermal Ore Deposits; Barnes, H.L., Ed.; John Wiley \& Sons: New York, NY, USA, 1997; Volume 1, pp. 737-796.

96. Hedenquist, J.W.; Lowenstern, J.B. The role of magmas in the formation of hydrothermal ore deposits. Nature 1994, 370, 519-527. [CrossRef]

97. Simmons, S.F.; White, N.C.; John, D.A. Geological characteristics of epithermal precious and base metal deposits. In One Hundredth Anniversary Volume; Hedenquist, J.W., Thompson, J.F.H., Goldfarb, R.J., Richards, J.P., Eds.; Society of Economic Geologists: Littleton, CO, USA, 2005; pp. 485-522. ISBN 9781887483018.

98. Shakeri, A.; Moore, F.; Kompani-Zare, M. Geochemistry of the thermal springs of Mount Taftan, Southeastern Iran. J. Volcanol. Geotherm. Res. 2008, 178, 829-836. [CrossRef]

99. Ridley, J.R.; Diamond, L.W. Fluid chemistry of orogenic lode gold deposits and implications for genetic models. In Gold in 2000, Reviews in Economic Geology; Hagemann, S.G., Brown, P.E., Eds.; Reviews in Economic Geology; Society of Economic Geologists: Boulder, CO, USA, 2000; Volume 13, pp. 141-162. ISBN 9781629490205.

100. Echeverri-Misas, C.M. Evolução Magmática, Alteração Hidrotermal e Gênese da Mineralização de Ouro e Cobre do Palito, Província Aurífera do Tapajós (PA). Master's Thesis, Universidade de São Paulo, São Paulo, Brazil, 2010.

101. Assunção, R.F.S.; Klein, E.L. The Moreira Gomes deposit of the Cuiú-Cuiú Goldfield: Fluid inclusions and stable isotope constraints and implications for the genesis of granite-hosted gold mineralization in the Tapajós Gold Province, Brazil. J. S. Am. Earth Sci. 2014, 49, 85-105. [CrossRef]

102. Deyell-Wurst, C.; Rye, R.; Landis, G.P.; Bissig, T. Alunite and the role of magmatic fluids in the Tambo high-sulfidation deposit, El Indio-Pascua Belt, Chile. Chem. Geol. 2005, 215, 185-218. [CrossRef]

103. Prenn, N.; Peralta, E.; Breckenridge, L.; Sim, R.; Davis, B.M.; King, N.; Michel, R.; Fisher, B.; Smith, M. NI 43-101 Technical Report of Coringa Gold Project, Brazil. Mineral Resource Estimate; MTB Project Management Professionals, Inc.: Greenwood Village, CO, USA, 2017.

104. Olin, E.J.; Cole, G.; Willow, M.A.; Olson, T.R. Canadian National Instrument 43-101 (NI 43-101) Technical Report Prepared by Inc. ("SRK") on the Palito Mining Complex; SRK Consulting (US): Denver, CO, USA, 2018.

105. Guimarães, S.B.; Klein, E.L. Geochemical and isotopic constraints on the host rocks of the magmatic-hydrothermal Coringa gold-silver $(\mathrm{Cu}-\mathrm{Pb}-\mathrm{Zn})$ Deposit of the Tapajós Mineral Province, Amazonian Craton, Brazil. J. S. Am. Earth Sci. 2020, 103, 102726. [CrossRef]

106. Wang, L.; Qin, K.-Z.; Song, G.-X.; Li, G.-M. A Review of intermediate sulfidation epithermal deposits and subclassification. Ore Geol. Rev. 2019, 107, 434-456. [CrossRef] 
107. Corrêa-Lima, R.G.; Klein, E.L. Hydrothermal alteration, mineralization and fluid inclusions in the Pista and Fofão prospects: Implications for the genetic model of the Coringa polymetallic deposit, SE Tapajós Mineral Province, Amazonian Craton, Brazil. J. Geol. Surv. Braz. 2020, 3, 33-59. [CrossRef]

108. Oliveira, H.T.d.; Borges, R.M.K.; Klein, E.L.; Lamarão, C.N.; Marques, G.T.; Lima, R.G.C. Alteração hidrotermal e fluidos mineralizantes no alvo Jerimum de Baixo, campo mineralizado do Cuiú-Cuiú, Província Aurífera do Tapajós: Um estudo baseado em petrografia, inclusões fluidas e química mineral. Geol. USP Série Científica 2019. [CrossRef]

109. Veloso, Â.S.R.; Santos, M.D.; Rios, F.J. Evolução dos fluidos mineralizantes e modelo genético dos veios de quartzo auríferos em zona de cisalhamento do depósito Ouro Roxo, Província Tapajós, Jacareacanga (PA), Brasil. Braz. J. Geol. 2013, 43, 725-744. [CrossRef]

110. Silva Júnior, C.A.d.S.; Klein, E.L. Geologia e características do fluido mineralizador dos alvos Auríferos Jerimum de Cima e Babi, campo mineralizado do Cuiú-Cuiú, Província Aurífera do Tapajós, Cráton Amazônico, com base em estudos de inclusões fluidas e de isótopos estáveis. Boletim do Museu Paraense Emílio Goeldi de Ciências Naturais 2015, 10, 199-230.

111. Rodrigues, R.M. Caracterização geológica e metalogenética do Depósito X1—Província Aurífera de Alta Floresta, Região de Matupá (MT). Master's Thesis, Universidade Estadual de Campinas, Campinas, Brazil, 2012.

112. Silva, M.L.T. Geologia, Petrologia e Metalogenia do Depósito de Ouro Santa Helena, Mato Grosso. Master's Thesis, Universidade de Brasília, Brasília, Brazil, 2017.

113. Assis, R.R.d.; Xavier, R.P.; Paes de Barros, A.J.; Souza-Filho, R. Trace element geochemistry and fluid regimes in gold deposits of the Alta Floresta Province. In Proceedings of the 44th Congresso Brasileiro de Geologia, Curitiba, Brazil, 26-31 October 2008; Sociedade Brasileira de Geologia: Belém, Brazil, 2008.

114. Feio, J.V.B. Petrografia das Rochas Hospedeiras e do Minério Aurífero e Estudo de Isótopos de Chumbo no alvo Mato Velho, SE da Província Aurífera do Tapajós, Pará. Bachelor's Thesis, Universidade Federal do Pará, Belém, Brazil, 2014.

115. Corrêa-Silva, R.H.; Juliani, C.; Chissini, G.B.; Benevides, T. Estruturas e texturas de um sistema epitermal low-sulfidation paleoproterozóico na Província Aurífera do Tapajós. In Proceedings of the II Simpósio de Vulcanismo e Ambientes Associados, Belém, Brazil, 10-14 November 2002; Sociedade Brasileira de Geologia: Belém, Brazil, 2002; pp. 20-21.

116. Sutherland, D.; Gradim, R.J.; Nilsson, J.; Rosario, P.P.; McKenzie, W.; da Franca, P.R.B. Technical Report Tocantinzinho Project Brazil; Eldorado Gold Corporation: Vancouver, BC, Canada, 2019.

117. Villas, R.; Santiago, É.S.B.; Castilho, M. Contexto geológico, estudos isotópicos (C, O-Pb) e associação metálica do depósito aurífero Tocantinzinho, Domínio Tapajós, Província Tapajós-Parima. Geol. USP Série Científica 2013, 13, 119-138. [CrossRef]

118. Santos, M.D.; Aquino, L.B.M.; Serra, V.F.H.; Gomes, M.V.; Galarza, M.A.; Lafon, J.M. Geocronologia das rochas hospedeiras e do minério com implicações na gênese do depósito Aurífero Palito, Província Tapajós, sudoeste do Pará. In Proceedings of the XIII Simpósio de Geologia da Amazônia, Belém, Brazil, 26-27 September 2013; Sociedade Brasileira de Geologia-SBG/Núcleo Norte: Belém, Brazil, 2013.

119. Lima, M.V.G.R. Geologia e Geocronologia do Depósito Aurífero do Palito, Província do Tapajós, Itaituba-PA. Bachelor's Thesis, Universidade Federal do Pará, Belém, Brazil, 2010.

120. Stubens, T.C.; Hennessey, B.T.; Gowans, R.M. Cabral Gold Files NI 43-101 Technical Report on the Cuiú-Cuiú Project, Mineral Resource Estimate, Pará State, North-Central Brazil; Toronto, Canada, 2018. Cabral Gold Inc. Available online: https:/ / cabralgold. com/site/assets/files/4292/cabral_technical_report_amended_181219.pdf (accessed on 20 November 2020).

121. Silva Júnior, C.A.S.; Klein, E.L.; Galarza, M.A.; Borges, R.M.K.; Queiroz, J.D.S.; Assunção, R.F.S.; Araújo, A.C.S.; Moore, D.J. Zircon geochronology and $\mathrm{Pb}$ isotope systematics in sulfides: Implications for the genesis of gold mineralization in the Cuiú-Cuiú Goldfield, Tapajós Gold Province, Amazonian Craton, Brazil. In Contribuições à Geologia da Amazônia; Gorayaeb, P.S.S., Lima, A.M.M., Eds.; SBG-Núcleo Norte: Belém, Brazil, 2015; pp. 453-465.

122. Veloso, Â.S.R.; Santos, M.D. Geologia, petrografia e geocronologia das rochas do depósito Aurífero Ouro Roxo, Província Tapajós, Jacareacanga (PA), Brasil. Braz. J. Geol. 2013, 43, 22-36. [CrossRef]

123. Klein, E.L.; Rosa-Costa, L.T.; Vasquez, M.L. Metalogênese da borda oriental do Cráton Amazônico. In Metalogênese das Províncias Tectônicas Brasileiras; Silva, M.G., Rocha Neto, M.G., Jost, H., Kuyumajian, R.M., Eds.; CPRM—Serviço Geológico do Brasil: Belo Horizonte, Brazil, 2014; Volume 1, pp. 171-194.

124. Rodriguez, P.; Soares, L.M. São Jorge Gold Project, Pará State, Brazil. Independent Technical Report on Mineral Resources; Brazil Resources Inc.: Belo Horizonte, Brazil, 2014. Available online: http://g1.brazilresources.com/_resources/SaoJorgeTechnicalReport. pdf (accessed on 20 November 2020).

125. Borges, R.M.K.; Dall'Agnol, R.; Lamarão, C.N.; Figueiredo, M.A.B.M.; Leite, A.A.d.S.; Barros, C.E.d.M.; Costi, H.T. Petrografia, química mineral e processos hidrotermais associados ao depósito de ouro São Jorge, Província Aurífera do Tapajós, Cráton Amazônico. Rev. Bras. Geociências 2009, 39, 375-393. [CrossRef]

126. Keller, G.F.; Couture, J.F. Vila Porto Rico Project Mineral Resource Technical Report, Pará State, Brazil; Amerix Precious Metals Corp. SRK Project Number 3UA015.000; Amerix Precious Metals Corp.: Toronto, ON, Canada, 2006.

127. Srivastava, M.; Rodriguez, P.C. NI 43-101 Technical Report Mineral Resource Update for the Castelo de Sonhos Gold Project, Pará State, Brazil; TriStar Gold Inc.: Belo Horizonte, Brazil, 2020. Available online: https:/ / www.tristargold.com/site/assets/files/3927 /techreport_final_20210429.pdf?gm95z (accessed on 20 November 2020). 
128. Klein, E.L.; Rodrigues, J.B.; Queiroz, J.D.S.; Oliveira, R.G.; Guimarães, S.B.; Chaves, C.L. Deposition and tectonic setting of the Palaeoproterozoic Castelo dos Sonhos metasedimentary formation, Tapajós Gold Province, Amazonian Craton, Brazil: Age and isotopic constraints. Int. Geol. Rev. 2017, 59, 864-883. [CrossRef]

129. Queiroz, J.D.S.; Klein, K.; Rodrigues, J.B. Rochas intrusivas na Formação Castelo dos Sonhos, Cráton Amazônico: Petrografia, geoquímica e implicações para as idades de sedimentação e da mineralização do depósito aurífero Castelo de Sonhos. Boletim do Museu Paraense Emílio Goeldi, Ciências Naturais 2015, 10, 341-380.

130. Appleyard, N.; Brown, A.; Srivastava, M. National Instrument 43-101 Technical Report Exploration Target Range for the Castelo de Sonhos Gold Project Pará State—Brazil; TriStar Gold Inc.: Belo Horizonte, Brazil, 2016.

131. Queiroz, J.D.d.S.; Klein, E.L. The Paleoproterozoic metaconglomerate-hosted Castelo de Sonhos gold deposit, Tapajós Gold Province, Amazonian Craton: A modified paleoplacer origin. J. Geol. Surv. Braz. 2018, 1, 81-99. [CrossRef]

132. Quispe, P.E.C. Geologia, Geoquímica e Geocronologia dos Granitoides Foliados e Rochas Subvulcânicas da Região de Peixoto de Azevedo, setor leste da Província Aurífera de Alta Floresta, Mato Grosso. Master's Thesis, Universidade Estadual de Campinas, Campinas, Brazil, 2016.

133. Serrato, A.A.A. Geocronologia e Evolução do Sistema Hidrotermal do Depósito Aurífero de Juruena, Província Aurífera de Alta Floresta (MT), Brasil. Master's Thesis, Universidade Estadual de Campinas, Campinas, Brazil, 2014.

134. Assis, R.R.d.; Xavier, R.P.; Creaser, R.A. Linking the timing of disseminated granite-hosted gold-rich deposits to Paleoproterozoic felsic magmatism at Alta Floresta Gold Province, Amazon Craton, Brazil: Insights from pyrite and molybdenite Re-Os geochronology. Econ. Geol. 2017, 112, 1937-1957. [CrossRef]

135. Pimenta, V.A. Alteração Hidrotermal e Deformação no Depósito do Peteca, Província Aurífera de Alta Floresta (PAAF), Região de Peixoto de Azevedo-MT. Master's Thesis, Universidade Estadual de Campinas, Campinas, Brazil, 2018.

136. Poggi, L. The Au-Cu-Mo Paraíba Deposit (MT): Integration of Spectral and Conventional Techniques for Mineral Exploration. Master's Thesis, Universidade Estadual de Campinas, Campinas, Brazil, 2019.

137. Gustafson, L.B.; Hunt, J.P. The porphyry copper deposit at El Salvador, Chile. Econ. Geol. 1975, 70, 857-912. [CrossRef]

138. Silva, A.C. Geotermobarometria de Clorita e Muscovita do Garimpo Aurífero do Papagaio, Província de Alta Floresta (MT). Bachelor's Thesis, Universidade de São Paulo, São Paulo, Brazil, 2019.

139. Calaboni, R. Química Mineral da Clorita e Muscovita do Depósito de Au \pm Cu Disseminado do Pé Quente, na Província Aurífera de Alta Floresta (MT). Bachelor's Thesis, Universidade Estadual Júlio de Mesquita Filho, Rio Claro, Brazil, 2018.

140. Perez, A.I. Química Mineral da Clorita e Mica Branca do Depósito Paleoproterozoico do Luizão, Província Aurífera de Alta Floresta (MT), Sul do Cráton Amazônico. Bachelor's Thesis, Universidade Estadual Júlio de Mesquita Filho, Rio Claro, Brazil, 2018

141. Moreira, I.C. Petrogênese dos Granitoides e Rochas Ortoderivadas do DEPÓSITO Paraíba, Peixoto de Azevedo, Província Aurífera de Alta Floresta, Cráton Amazônico. Master's Thesis, Universidade Estadual de Campinas, Campinas, Brazil, 2019.

142. Meyer, A. Elementos Traço em Pirita e Calcopirita por Microssonda Eletrônica em Depósitos Auríferos Filonares da Província Aurífera de Alta Floresta (MT), Cráton Amazônico. Bachelor's Thesis, Universidade Estadual Júlio de Mesquita Filho, Rio Claro, Brazil, 2017.

143. Siqueira, L.C. Geotermobarometria da clorita e mica branca hidrotermais do depósito filonar de Au \pm Cu do Edu, Província Aurífera de Alta Floresta (MT). Bachelor's Thesis, Universidade Estadual Júlio de Mesquita Filho, Rio Claro, Brazil, 2018.

144. Sacks, I.S. The Subduction of young lithosphere. J. Geophys. Res. 1983, 88, 3355-3366. [CrossRef]

145. Ferrari, L.; Orozco-Esquivel, T.; Manea, V.; Manea, M. The dynamic history of the Trans-Mexican Volcanic Belt and the Mexico Subduction Zone. Tectonophysics 2012, 522-523, 122-149. [CrossRef]

146. Manea, V.C.; Manea, M.; Ferrari, L.; Orozco-Esquivel, T.; Valenzuela, R.W.; Husker, A.; Kostoglodov, V. A review of the geodynamic evolution of flat slab subduction in Mexico, Peru, and Chile. Tectonophysics 2017, 695, 27-52. [CrossRef]

147. Arce, J.L.; Ferrari, L.; Morales-Casique, E.; Vasquez-Serrano, A.; Arroyo, S.M.; Layer, P.W.; Benowitz, J.; López-Martínez, M. Early Miocene arc volcanism in the Mexico City Basin: Inception of the Trans-Mexican Volcanic Belt. J. Volcanol. Geotherm. Res. 2020, 408, 107104. [CrossRef]

148. Kay, S.M.; Godoy, E.; Kurtz, A. Episodic arc migration, crustal thickening, subduction erosion, and magmatism in the south-central Andes. Geol. Soc. Am. Bull. 2005, 117, 67-88. [CrossRef]

149. Goss, A.R.; Kay, S.M.; Mpodozis, C. Andean adakite-like high-Mg andesites on the northern margin of the Chilean-Pampean flat-slab $\left(27-28 \cdot 5^{\circ} \mathrm{S}\right)$ associated with frontal arc migration and fore-arc subduction erosion. J. Petrol. 2013, 54, 2193-2234. [CrossRef]

150. Mulcahy, P.; Chen, C.; Kay, S.M.; Brown, L.D.; Isacks, B.L.; Sandvol, E.; Heit, B.; Yuan, X.; Coira, B.L. Central Andean mantle and crustal seismicity beneath the southern Puna Plateau and the northern margin of the Chilean-Pampean flat slab. Tectonics 2014, 33, 1636-1658. [CrossRef]

151. Tokashiki, C.C. Mineralizações Low- e Intermediate-Sulfidation de Ouro e de Metais de Base em Domos de Riolito Paleoproterozoicos na Porção sul da Provincia Mineral do Tapajós. Ph.D. Thesis, Universidade de São Paulo, São Paulo, Brazil, 2015.

152. Pacey, A.; Wilkinson, J.J.; Owens, J.; Priest, D.; Cooke, D.R.; Millar, I.L. The anatomy of an alkalic porphyry Cu-Au system: Geology and alteration at Northparkes mines, New South Wales, Australia. Econ. Geol. 2019, 114, 441-472. [CrossRef]

153. Thompson, J.F.H.; Sillitoe, R.H.; Baker, T.; Lang, J.R.; Mortensen, J.K. Intrusion-Related Gold Deposits associated with tungsten-tin provinces. Miner. Depos. 1999, 34, 323-334. [CrossRef]

154. Lang, J.; Baker, T. Intrusion-Related Gold Systems: The present level of understanding. Miner. Depos. 2001, 36, 477-489. [CrossRef] 
155. Hughes, E.D.; Ingold, C.K.; Wilson, C.L. Concentration of heavy water by spontaneous evaporation. Nature 1934, $134,142$. [CrossRef]

156. Camprubí, A.; Albinson, T. Depósitos epitermales en México: Atualización de su conocimiento y reclasificatión empírica. Boletín de La Sociedad Geológica Mexicana 2006, 58, 27-81. [CrossRef]

157. Fayol, N.; Jébrak, M. Archean sanukitoid gold porphyry deposits: A new understanding and genetic model from the Lac Bachelor gold deposit, Abitibi, Canada. Econ. Geol. 2017, 112, 1913-1936. [CrossRef]

158. Choi, S.-G.; Ryu, I.-C.; Pak, S.J.; Wee, S.-M.; Kim, C.S.; Park, M.-E. Cretaceous epithermal gold-silver mineralization and geodynamic environment, Korea. Ore Geol. Rev. 2005, 26, 115-135. [CrossRef]

159. So, C.-S.; Yun, S.-T.; Shelton, K.L.; Zhang, D.-Q. Geochemistry of the Youngbogari deposit, Republic of Korea: An unusual mesothermal gold-silver deposit of the Youngdong area. Geochem. J. 2002, 36, 155-171. [CrossRef]

160. Wilson, A.J.; Cooke, D.R.; Harper, B.J.; Deyell, C.L. Sulfur isotopic zonation in the Cadia district, southeastern Australia: Exploration significance and implications for the genesis of alkalic porphyry gold-copper deposits. Miner. Depos. 2007, 42, 465-487. [CrossRef]

161. Holliday, J.R.; Wilson, A.J.; Blevin, P.L.; Tedder, I.J.; Dunham, P.D.; Pfitzner, M. Porphyry gold-copper mineralisation in the Cadia district, eastern Lachlan Fold Belt, New South Wales, and its relationship to shoshonitic magmatism. Miner. Depos. 2002, 37, 100-116. [CrossRef]

162. Gaboury, D. Parameters for the formation of orogenic gold deposits. Appl. Earth Sci. 2019, 128, 124-133. [CrossRef]

163. Goldfarb, R.J.; Baker, T.; Dube, B.; Groves, D.I.; Hart, C.J.R.; Gosselin, P. Distribution, character and genesis of gold deposits in metamorphic terranes. In Economic Geology One Hundredth Anniversary Volume; Hendequist, J.W., Thompson, J.F.H., Goldfaber, R.G., Richards, J.P., Eds.; Society of Economic Geology: Littleton, CO, USA, 2005; Volume 1, pp. 407-450.

164. Tomkins, A. Windows of metamorphic sulfur liberation in the crust: Implications for gold deposit genesis. Geochim. Cosmochim. Act 2010, 74, 3246-3259. [CrossRef]

165. Zhong, R.; Brugger, J.; Tomkins, A.; Li, W. Fate of gold and base metals during metamorphic devolatilization of a pelite. Geochim. Cosmochim. Acta 2015, 171, 338-352. [CrossRef]

166. Camprubí, A.; Albinson, T. Epithermal deposits in México-Update of current knowledge, and an empirical reclassification. Geol. Soc. Am. Spec. Pap. 2007, 422, 377-415. [CrossRef]

167. Hedenquist, J.W.; Henley, R.W. The importance of $\mathrm{CO}_{2}$ on freezing point measurements of fluid inclusions-Evidence from active geothermal systems and implications for epithermal ore deposition. Econ. Geol. 1985, 80, 1379-1406. [CrossRef]

168. Klein, E.L.; Vasquez, M.L.; da Rosa-Costa, L.T.; de Azevedo Carvalho, J.M. Geology of Paleoproterozoic gneiss-and granitoidhosted gold mineralization in outhern Tapajós Gold Province, Amazonian Craton, Brazil. Int. Geol. Rev. 2002, 44, 544-558. [CrossRef]

169. Jébrak, M. Hydrothermal breccias in vein-type ore deposits: A review of mechanisms, morphology and size distribution. Ore Geol. Rev. 1997, 12, 111-134. [CrossRef]

170. Lawless, J.V.; White, P.J. Ore-related breccias: A revised genetic classification, with particular reference to epithermal deposits. In Proceedings of the 12th New Zealand Geothermal Workshop; Harvey, C., Browne, P., Freestone, D., Scott, G., Eds.; Geothermal Institute, University of Auckland: Auckland, New Zealand, 1990; pp. 197-202.

171. Mernagh, T.P.; Leys, C.; Henley, R.W. Fluid inclusion systematics in porphyry copper deposits: The super-giant Grasberg deposit, Indonesia, as a case study. Ore Geol. Rev. 2020, 123, 103570. [CrossRef]

172. Lecumberri-Sanchez, P.; Steele-MacInnis, M.; Weis, P.; Driesner, T.; Bodnar, R.J. Salt precipitation in magmatic-hydrothermal systems associated with upper crustal plutons. Geology 2015, 43, 1063-1066. [CrossRef]

173. Kuehn, C.A.; Rose, A.W. Carlin gold deposits, Nevada; Origin in a deep zone of mixing between normally pressured and overpressured fluids. Econ. Geol. 1995, 90, 17-36. [CrossRef]

174. Zuza, A.V.; Levy, D.A.; Mulligan, S.R. Geologic field evidence for non-lithostatic overpressure recorded in the North American Cordillera Hinterland, northeast Nevada. Geosci. Front. 2020, 101099. [CrossRef]

175. Albuquerque, D.F.; França, G.S.; Moreira, L.P.; Assumpção, M.; Bianchi, M.; Barros, L.V.; Quispe, C.C.; Oliveira, M.E. Crustal structure of the Amazonian Craton and adjacent provinces in Brazil. J. S. Am. Earth Sci. 2017, 79, 431-442. [CrossRef]

176. Petrini, K.; Podladchikov, Y. Lithospheric pressure-depth relationship in compressive regions of thickened crust. J. Metamorph. Geol. 2000, 18, 67-77. [CrossRef]

177. Goldfarb, R.; Groves, D.I.; Gardoll, S. Orogenic gold and geologic time: A global synthesis. Ore Geol. Rev. 2001, 18, 1-75. [CrossRef]

178. Camprubí, A.; González-Partida, E.; Levresse, G.; Tritlla, J.; Carrillo-Chávez, A. Depósitos epitermales de alta y baja sulfuración: Una tabla comparativa. Boletín de la Sociedad Geológica Mexicana 2003, LVI, 10-18. [CrossRef]

179. Hedenquist, J.W.; Arribas, A., Jr.; Gonzalez-Urien, E. Exploration for epithermal gold deposits. In Gold in 2000, Reviews in Economic Geology; Hagemann, S.G., Brown, P.E., Eds.; Society of Economic Geologists: Boulder, CO, USA, 2000; Volume 13, pp. $245-277$.

180. Seedorff, E.; Dilles, J.H.; Proffett, J.M., Jr.; Einaudi, M.T.; Zurcher, L.; Stavast, W.J.A.; Johnson, D.A.; Barton, M.D. Porphyry deposits: Characteristics and origin of hypogene features. In Economic Geology One Hundredth Anniversary Volume; Hedenquist, J.W., Thompson, J.F.H., Goldfarb, R.J., Richards, J.P., Eds.; Society of Economic Geologists: Littleton, CO, USA, 2005; Volume 1, pp. 251-298. ISBN 9781887483018. 
181. Groves, D.I.; Goldfarb, R.J.; Gebre-Mariam, M.; Hagemann, S.G.; Robert, F. Orogenic gold deposits: A proposed classification in the context of their crustal distribution and relationship to other gold deposit types. Ore Geol. Rev. 1998, 13, 7-27. [CrossRef]

182. Lowenstern, J.B. Carbon dioxide in magmas and implications for hydrothermal systems. Miner. Depos. 2001, 36, 490-502. [CrossRef]

183. Mesquita, M.J.; Assis, R.R.; Xavier, R.P.; Moretto, M.S.; Paes de Barros, A.J.; Miguel Júnior, E. Ductile shear zone-hosted gold deposits in the Paleoproterozoic Alta Floresta Province (Brazil). In Proceedings of the 13th SGA Biennial Meeting: Mineral Resources in a Sustainable World, Nancy, France, 24-27 August 2015; André-Mayer, A.-S., Cathelineau, M., Muchez, P., Pirard, E., Sindern, S., Eds.; Society of Geology Applied to Mineral Deposits: Mountain View, CA, USA; p. 141.

184. Sinclair, W. Porphyry deposits. In Mineral Deposits of Canada-A Synthesis of Major Deposit Types, District Metallogeny, the Evolution of Geological Provinces, and Exploration Methods; Goodfellow, W.D., Ed.; Geological Association of Canada, Mineral Deposits Division, Special Publication: St. Johns, NL, Canada, 2007; Volume 5, pp. 223-243. ISBN 978-1-897095-24-9.

185. Richards, J.P. Postsubduction porphyry $\mathrm{Cu}-\mathrm{Au}$ and epithermal Au deposits: Products of remelting of subduction-modified lithosphere. Geology 2009, 37, 247-250. [CrossRef] 